
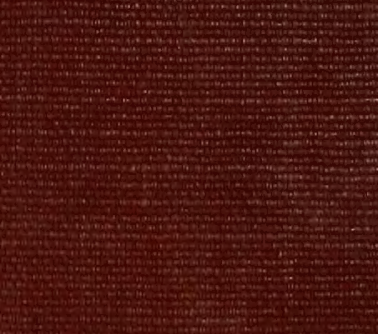

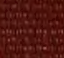





IDemotrs of the Museum of Comparative Zoölogy

AT HARVARD COLLEGE.

Vor. XLIV. No. 2.

\section{A CONTRIBUTION TO THE ZOÖGEOGRAPHY OF THE WEST INDIES, WITH ESPECIAL REFERENCE TO AMPHIBIANS AND REPTILES.}

BY

THOMAS BARBOUR.

WITH ONE PLATE.

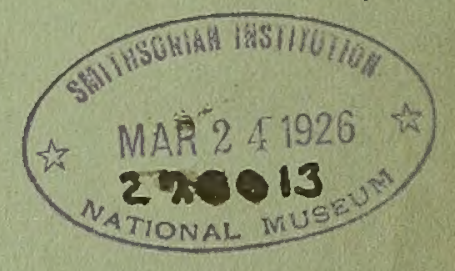

CAMBRIDGE, U.S.A.:

Drinted for the Suseum.

March, 1914. 



\section{IDemoirs of the SDuseum of Comparative Zoölogy \\ AT HARVARD COLLEGE. \\ Vol. XLIV. No. 2.}

\section{A CONTRIBUTION TO THE ZOÖGEOGRAPHY OF THE WEST INDIES, WITH ESPECIAL REFERENCE TO AMPHIBIANS AND REPTILES.}

BY

THOMAS BARBOUR.

WITH ONE PLATE.

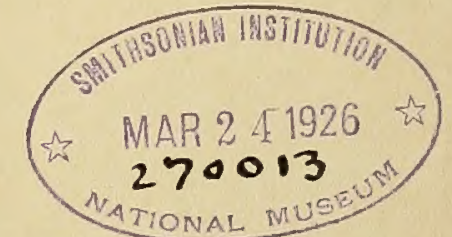

CAMBRIDGE, U.S.A.:

Drinted for the MDuseum.

MARCH, 1914. 



\section{TABLE OF CONTENTS.}

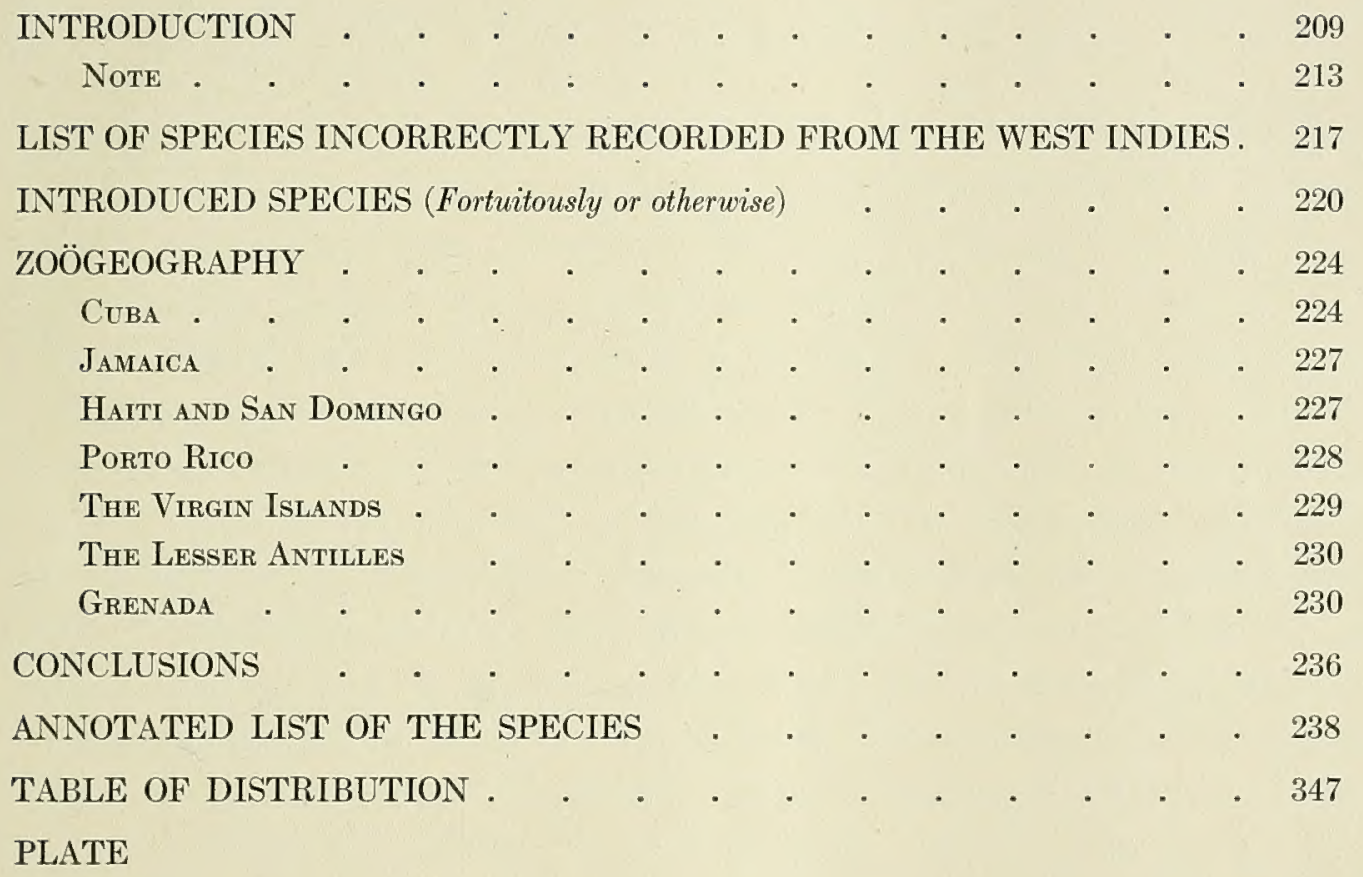





\section{A CONTRIBUTION TO TIIE ZOÖGEOGRAPHY OF THE WEST INDIES, WITH ESPECIAL REFERENCE TO AMPHIBIANS AND REPTILES.}

\section{INTRODUCTION.}

Since its earliest years the Museum of Comparative Zoölogy has received many collections representing the fauna of the West Indian Islands. To mention a few of these, Louis Agassiz and the other scientists on the Hassler collected at St. Thomas, on their memorable voyage; and later - from 1877 to 1880 - the BLAKE visited very many of the islands. The opportunity to collect upon all of them was eagerly grasped by Mr. Samuel Garman, who was Assistant Naturalist on the BLAKE during part of the time that she was in charge of Alexander Agassiz. Collections were procured upon other islands than those at which the BLAKE touched by the kindness of enthusiastic colonists and others. The material available from Porto Rico consists of some received from Dr. A. Stahl, long a resident of Bayamon; some collected by Garman; and other specimens got by exchange from the United States national museum, collected by Stejneger and Richmond. From San Domingo as well as Guadeloupe there are specimens sent to Louis Agassiz by Duméril from the Paris museum. This material has a unique value, since it formed in many cases part of the material studied by Duméril and Bibron for their great Erpétologie général. More recently there has been received material collected by Mr. A. H. Verrill at Santiago de la Vega. From Haiti the Museum contains the large collection of Weinland, made at Jeremie and other points in the western district of the island; and from this collection Cope described many of the species peculiar to the island, although some were described by Garman at a later date. The most recent Haitian material comes as a part of the results of Mr. W. M. Mann's trip to the island from November, 1912 to February, 1913. From Cuba there is material contributed by Filipe Poey, Samuel H. Scudder, Wirt Robinson, and others. I have added to the collections the material collected during trips to the Bahamas, Cuba, and Jamaica. One of the special incentives to writing this paper was afforded by a large and finely preserved collection received from Grenada. 
During a part of the summer of 1910 (August 17 to September 25) Messrs. G. M. Allen and C. T. Brues worked at Grenada in the interest of the Museum of Comparative Zoölogy. In view of the fact that in several branches the $\mathrm{Mu}$ seum already possessed adequate collections from this island, special efforts were made to collect only the most interesting and little-known elements in the fauna. Thus Dr. Allen discovered the armadillo, long known by hearsay only, which has proved to belong to a new race. He found besides several bats, either new species, or others of special interest. No attempt was made to do any marine collecting. Only few birds were wanted; and concerning these a short paper has been published (Barbour, Proc. Biol. soc. Wash., 1911, 24, p. 57-60). Mr. Brues devoted himself particularly to the insects; and, as a result, some fine material was procured. Prof. W. M. Wheeler has already written upon the ants (Bull. M. C. Z., 1911, 54, p. 167-172). Of more importance from a zoögeographical point of view was the finding, by both Allen and Brues, of specimens of a new species of Peripatus (Brues, Bull. M. C. Z., 1911, 54, p. 303-318). No Peripatus had previously been known from Grenada; and its close affinity with species in Trinidad and Guiana, together with the distinctness due to its isolated island life, make it important evidence, first, that it was not brought to Grenada by human agency, or otherwise fortuitously; secondly, that Grenada has never been completely submerged since its first separation from South America on the one hand and Antillea on the other. The species is extremely rare, and its distribution is very closely confined to a small highland area of virgin forest in the middle of the island. It does not, so far as their careful collecting goes to prove, ever occur in the low, cultivated lands, or in the Botanic gardens.

Dr. Allen and Mr. Brues made important archaeological collections, so that the trip was a most successful one.

It has already been mentioned that during the cruises of the BLAKE Mr. Alexander Agassiz was accompanied by Mr. Samuel Garman. After their return to Cambridge, Garman published his well-known series of papers dealing with the reptiles and amphibians of the various islands. Considering the fact that the time on shore was always limited to the short stay while the ship was in port, the collections are a monument to Mr. Garman's prodigious industry. But more important than the gathering of the material was the advance in method he made in studying it. He was the first to recognize that the various species existing in the Antilles did not occur scattered in a perfectly reasonless way upon various islands; but rather that each island possessed a fauna with certain well-marked features, and usually as well with well-marked local species 
or races related to, but differentiated by isolation from, the forms found on the neighboring islands. At first, certain of the so-called conservative zoölogists objected at the making of such a large number of new species. Time, however, has justified Garman's work to a large extent.

Since the original writing of this paper Mrs. Barbour and I again visited Cuba (January-March, 1910) for the purpose of filling as many gaps as possible in the collection by collecting at localities in the island from which there was previously no material in the Museum. Cuban material is peculiarly important in this connection because of the close relationship of many Bahaman and Haitian species with those on Cuba. There has been question as to the identity or distinctness of these, and there are also many interesting and important points regarding the relative abundance and local distribution of species within the island. I left for Havana January 30th, and went directly to Soledad estate, near Cienfuegos, where I received the kind hospitality of Mr. Edwin F. Atkins and his family; and much aid, especially from Mr. R. M. Grey, who is in charge of the Harvard Botanical Station, and Captain Beal, of Colonia Guabairo who was more than kind to Mrs. Barbour and myself. From Soledad we returned to Havana, and were joined by Dr. and Mrs. J. L. Bremer. To Dr. Bremer I owe many thanks for his aid to my collecting. Together we visited Herradura, San Diego de los Baños, and the city and vicinity of Pinar del Rio, then later Madruga. We returned to Cambridge on March 15th. The notes on these specimens have been incorporated into the paper which was previously written. In connection with this Cuban trip, it is a great pleasure to thank my old friend, Dr. Aristides Mestre, Assistant Professor in the University of Havana, and Dr. Carlos de la Torre, Professor in the University of Havana, for much kind advice and other aid, as well as for some very valuable books and specimens.

A delay in the publication of the paper enables me to include the results of my stay in Cuba during January-March, 1913. Prof. W. M. Wheeler and Mr. Louis A. Shaw were with me for the first two weeks and during the entire excursion I had the very great advantage and pleasure of the company of Dr. de la Torre and of his assistant Mr. V. J. Rodriguez. Upon this trip we devoted some attention to birds and mammals with uniform good fortune since many of the rarest and most interesting species were secured. Our first trip from Havana was to Bolondron where we were hospitably entertained by Mr. Edwin F. Sanborn at the InGEnio ARMonia, from here we reached the edge of the Cienaga de Zapata at Hato Jicarito. From Bolondron we went to Aguada de Pasajeros which we made 
a base for several excursions into the neighborhood, spending several days at the edge of the great Cienaga in a house kindly placed at our use by Sr. Francisco Morales. Sr. Morales's cane fields at Colonia San Francisco are on the Rio Hanabana and the enormous saw-grass morasses may be conveniently reached by horse-back. Travel in the swamp is quite a different matter to reaching the edge, however, although it is remarkable to see through how deep mud the horses will carry one before they must be left. The uneven hard substratum upon which the mud, covered with floating vegetation, rests almost in a liquid state makes riding quite exciting and it is not uncommon for one's horse to flounder into a depression almost disappearing in the ooze to be gotten out with some difficulty.

Crocodilus rhombifer the true Cuban crocodile was abundant about the Laguna de Punta Gorda which was perhaps our most productive collecting ground.

By the courtesy of Sr. Freyre and Sr. don Miguel Diaz the railways and other means of transport on the great estates of MARIA Victoria and PerseVERANCIA were at our disposal and our hearty thanks are due them for much courtesy and aid.

We returned to Havana from Aguada and Messrs. Wheeler and Shaw left for the North while Mr. Rodriguez and myself made a short excursion to Matanzas, Union de Reyes and Alacranes (Alfonso XII). Our object was to secure blind fishes and Crustacea from the caves of the southern part of Matanzas province and in this we were successful.

Returning again to Havana Professor de la Torre joined us and we started at once for Bayamo. From here we proceeded to Baire by rail and then by horseback to the village of Los Negros where we stayed some time and to Pozo Prieto. Near the latter locality we spent several days at the cafetal El Alto of Sr. Pedro Diaz which was a fine locality in the heart of the humid forest region of the Sierra Maestra. Returning to Bayamo our party divided, Señor Rodriguez going to Bueycito and the region of the Pan de Azucar while Professor de la Torre and myself went to Manzanillo and by various stages south to Cabo Cruz. Here the successful search was made for Cricosaura and Tarentola. After this trip we went back to Manzanillo, to San Luis and then to Guantanamo. Here we stayed with Mr. C. T. Ramsden whose study of Cuban birds is well known. A return to Bayamo and Havana with a few short days there together with Mrs. Barbour, who came down to meet me ended a most charming and profitable trip. Our collection was small but the common 
species were already well represented and only such species as were especially desirable were searched for.

The revival of interest in zoögeography has prompted making this paper more than a simple check list, although such a list of the reptiles and amphibians of the Antilles has long been needed. The species which are included in this list are only those which seem to be worthy of recognition; all other recorded species are considered synonyms or incorrect records for the area. This comprises the Bahamas, Greater and Lesser Antilles as far south as Grenada; Swan Islands and the Cayman group are also included. As stated elsewhere among the notes on certain species, the practice has been followed of recognizing island races as far as possible. It is considered that a more incorrect concept is gained regarding the conditions among these islands by stating that the same species occurs upon several islands, when there is generally a constant definitive variation seen in individuals from each island, even though in some cases this variation appears to be slight. Jordan's law of evolution by isolation has often been startlingly effective in producing very distinct species upon nearly adjacent islands, where these islands have apparently — indeed, one might say certainly exactly the same physical and climatic conditions.

No attempt is made to give complete synonymies; and unless some special comment is made, those species which have been considered synonyms by Boulenger in his catalogues are so accepted.

This paper must be considered in the nature of a preliminary, since unfortunately press of time and in many cases want of material have prevented the writing of a herpetology, with descriptions and keys for the identification of species. This list will show where reptile collecting in the West Indies can be carried on most profitably, what material from the region is available for study in the Museum of Comparative Zoölogy; and these records, which have been carefully culled, serve as a basis for certain considerations regarding the geographical distribution of Antillean reptiles and amphibians, and regarding the origin of this fauna.

Note.- After this paper was about completed, Mr. George Nelson of the Museum staff made three visits to the Swan Islands thanks to the kindness of Dr. W. A. Brooks. Together several months were spent there, and collections made in winter, spring, and summer. For the first time the islands have been studied by the same person at various times of the year. Mr. Nelson's material force the reconsideration of conclusions which maintain that the Swan Islands had an oceanic origin. Special mention may be made of the very strange fact 
that Mr. Nelson's collections prove definitely that Tiaporus fulginosus Cope, a teid genus supposedly peculiar to the islands does not occur there. The types were collected by Townsend in 1887 and there is documentary evidence in his correspondence with the U. S. national museum which leaves no doubt as to the fact that the type specimens were actually taken on Swan Island. If the species was confined to the larger island, it, being wholly terrestrial in habit, may have been exterminated by the introduced cats.

In 1911 Mr. Percy R. Lowe published a quite fascinating book, A Naturalist on Desert Islands, though why "desert islands" does not at once occur to one. Lowe spent three weeks about the Swan Islands on the yacht ZENAIDA landing frequently and making considerable collections. He is firmly convinced that they have never been in connection with any of the land masses which have in the past existed in the Caribbean region. The geologic evidence which he brings forward certainly supports his contention but, so far no borings have been possible to show the real underlying structure of the islands. The fauna is rich, equally so upon Little Swan, which has never been inhabited and cultivated, as upon the greater island, which has.

Remarking upon the indigenous species of hutia Lowe (p. 103) speaks of :-

"A strange race of vegetarian rats (Capromys), tree-dwellers or tree-climbers, and now almost extinct on other islands in the West Indies, but which found their way across the sea to Swan Island in the same fashion as the iguana, and there founded a specific race of their own."

Again on p. 112-114 we read:-

"This rat is of an extremely mild and almost genial disposition; has a head and body very much after the style of an enormous guinea-pig; and is covered with rather long and silky hairs protruding through a thick fur. Its specific name is Capromys thoracatus of True, and the species thoracatus is restricted to Swan Island. The genus Capromys to which it belongs is an interesting one; for it comprises arboreal forms which are only found in the larger West Indian Islands such as Cuba and Jamaica, where it is in imminent danger of becoming extinct. It is just possible, therefore, that Little Swan Island will, in the future, represent the last stronghold of this peculiar and old time race of rats, for here they are left absolutely unmolested; and no enemies, human or otherwise, seem likely to disturb them. Scientifically, these rats are allied to the coypu (Myopotamus) of South America; an animal attaining to the length of two feet, which lives in burrows near the water, and feeds on aquatic plants. How these rats came to find their way to Swan Island is a little point in the problem of the distribution of species which may be worth referring to; for as we have seen, there is every reason to suppose that Swan Island has never had any connection with the mainland, and is of infinitely later date, geologically speaking, than the islands comprising the Greater Antilles, being of quite recent coral origin. Indeed as far as its fauna is concerned, Swan Island might be looked upon as an oceanic or pseudo-oceanic island. ${ }^{1}$ If, as seems most likely, this Swan Island race 
of rats was derived from the race which inhabits Jamaica (C. melanurus) the original progenitors of the Swan Island species must have drifted over a sea space of at least three hundred and twenty miles; for Swan Island lies exactly that distance in an almost due westerly direction from the nearest point of Jamaica, along the course of the Gulf Stream. The genus is not found on the mainland of Honduras, ninety-eight miles to the south, which puts this comparatively short sea-route out of court.

For the sake of those who may not have given such a subject a thought, we might add that a journey of this nature across an open sea could only have been rendered possible by the rats having been carried out to sea by means of a floating island of vegetation, or a mass of entangled tree-trunks such as one often sees in mangrove swamps."

This entire account is so inaccurate that one's confidence in the author's interpretations and observations in geology are sadly shaken. This creature which is in no wise related to the rats except that it is a rodent, is not like $C$. melanurus which also, is not found on Jamaica. C. browni is the Jamaican form, a wholly distinct species now rare owing to mongoose ravages. C. melanurus is a long-tailed species from the high mountains of eastern Cuba. In Cuba two other species, $C$. pilorides and $C$. prehensilis, are abundant, the former extremely so. The genus is not, except for the Swan Island species, confined to the Greater Antilles, but a species, $C$. ingrahami, is found in the grass of one of the small lowlying Plana Keys of the southern Bahamas. It is mathematically improbable that an island of vegetation set afloat from a country like Jamaica where there are no rivers capable of performing this relatively rare phenomenon would be inhabited at the same time by a hutia. The island would also have to steer very carefully to meet Swan Island which is very small, and even granting that there was a current to carry it along or a suitable wind which would drive it two and one half miles an hour, without submerging it, one hundred and twenty-one hours approximately would be necessary for the voyage. Unless more than one hutia was carried on the island, this voyage would have to be performed by a second hutia which would have to reach the island before the death of the first. It is of course, improbable that these events have ever happened. The habits of the Jamaican Capromys are not such as to render it likely that it would ever have attempted so precarious a sea trip and there are no physical conditions in Jamaica which would have forced it to do so. Contrary to Lowe's assertion there are snakes upon the Islands, one of which represents an autocthonous race. Of course the absence of fresh water and other adverse physical features strictly limit the variety of living forms which the islands can support. Pulmonate gastropods ${ }^{1}$ occur and a variety of insects - so that the fauna is not surprisingly poor but

${ }^{1}$ For a notice of the affinities of the extremely interesting species of land shells peculiar to Swan Island, see Clapp, Nautilus, Jan. 1914, 27, No. 9, p. 97-101. 
rather the reverse. It will be surprising indeed if there is not geological evidence, however difficult it may be to find, which will prove that the Swan Islands are the remnants of an ancient land mass which once reached to Jamaica and perhaps, or even probably, also that commissure which once reached from the mainland to the east end of Cuba, via the Cayman Islands when the east end of Cuba was an island separate from the rest of what is now Cuba. Oceanic deeps are certainly not all of ancient origin; and there are many restricted areas of Cuba, Jamaica, or Florida which if, by some oscillatory or submerging process, they were left above the sea level and their surrounding areas had vanished would be as difficult as Swan Island is to prove their earlier connection with other land, near at hand or far away. 


\section{LIST OF SPECIES INCORRECTLY RECORDED FROM THE WEST INDIES.}

The following species which do not properly belong to the Antillean fauna are recorded by Reinhardt and Lütken in their Bidrag til det vestindiske öriges og navnligen til de Dansk-Vestindiske öers herpetology (Vid. Meddel. nat. foren. Kjöbenhavn for 1862, 1863, p. 150-291). These authorities have most carefully and exhaustively revised and tabulated all the records for this area, and it is therefore unnecessary to more than point out those that are evidently based upon wrongly labeled specimens, and then refer to Reinhardt and Lütken, who themselves were skeptical regarding very many of their records.

Name used by Reinhardt \& Lütken.

Bufo ornatus Spix.

Cystignathus ocellatus (Linné). Cystignathus typhonius Daudin.

Leiupurus marmoratus Duméril \& Bibron Hylaplesia picta Duméril \& Bibron.

Bothrops bilineatus (Wied) var. unicolor Jan. Crotalus horridus (Schlegel).

Elaps corallinus (Linné).

Elaps fulvius (Linné).

Elaps lemniscatus (Linné).

Geophis punctovittatus Jan.,

Homalocranium melanocephalum (Linné).

Homalocranium semicinctum Duméril \& Bibron.

Elapoides sieboldi Jan.

Streptophorus atratus Hallowell.

Erythrolamprus aesculapii (Linné).

Heterodon platyrhinus (Latreille).

Ischnognathus dekayi (Holbrook).

Gerarda bicolor Gray.

Hipistes fasciatus Gray.

Helicops angulatus (Linné).

Spilotes corais (Cuvier).

Spilotes pullatus (Linné).

Coryphodon constrictor (Linné).

Liophis reginae (Linné).

Lygophis lineatus (Linné).

Cyclophis aestivus (Linné).

Philodryas viridissimus (Linné).

Abaetulla liocercus (Boie).

Dryiophis acuminatus (Wied).
Name in present use.

Bufo crucifer Wied.

Leptodactylus ocellatus (Linné).

Leptodactylus typhonius (Daudin).

Paludicola marmoratus (Duméril \& Bibron).

Dendrobates trivittatus (Spix).

Lachesis bilineatus (Wied).

Crotalus horridus Linné.

Elaps corallinus (Linné).

Elaps fulvius (Linné).

Elaps lemniscatus (Linné).

Atractus trilineatus (Wagler).

Homalocranium melanocephalum (Linné).

Homalocranium semicinctum Duméril \&

Bibron.

Geophis chalybaeus (Wagler).

Streptophorus atratus Hallowell.

Erythrolamprus aesculapii (Linné).

Heterodon platyrhinos (Latreille).

Storeria dekayi (Holbrook).

Gerarda prevostiana (Eidoux \& Gervais).

Hipistes hydrinus (Cantor).

Helicops angulatus (Linné).

Spilotes corais (Cuvier).

Spilotes pullatus (Linné).

Zamenis constrictor (Linné).

Liophis reginae (Linné).

Aporophis lineatus (Linné).

Cyclophis aestivus (Linné).

Phylodryas olfersii (Lichtenstein).

Leptophis liocercus (Wied).

Oxybelis acuminatus (Wied). 
Name used by Reinhardt \& Lütken.

Dryiophis fronticinctus (Günther).

Leptodeira annulata (Linné).

Himantodes cenchoa (Linné).

Ophisaurus ventralis (Linné).

Plestiodon laticeps (Schneider).

Gymnophthalmus quadrilineatus (Linné).

Cnemidophorus murinus (Laurenti).

Cnemidophorus lemniscatus (Daudin).

Cnemidophorus sexlineatus (Linné).

Salvator teguixin (Linné).

Basiliscus americanus Laurenti.

Polychrus marmoratus (Linné).

Tropidolepis undulatus (Latreille).

Hypsibatus agamoides (Gray).

Alligator cynocephalus Duméril \& Bibron

Alligator punctulatus Spix.

Podocnemis dumeriliana (Schweiger).

Malacoclemys palustris (Gr.)

Emys scabra (Linné).

Emys concinna (Linné).

Cistudo carolina (Linné).
Name in present use.

Dryophis fronticinctus Günther.

Leptodeira annulata (Linné).

Himantodes cenchoa (Linné).

Ophisaurus ventralis (Linné).

Eumeces quinquelineatus (Linné).

Gymnophthalmus quadrilineatus (Linné).

Cnemidophorus murinus (Laurenti).

Cnemidophorus lemniscatus (Daudin).

Cnemidophorus sexlineatus (Linné).

Teius teguixin (Linné).

Basiliscus americanus Laurenti.

Polychrus marmoratus (Linné).

Sceloporus undulatus (Latreille).

Plica plica (Linné).

Cayman latirostris (Daudin).

Cayman sclerops (Schneider).

Podocnemis dumeriliana (Schweigger).

Malaclemys centrata (Latreille).

Chrysemys scripta (Schoepff).

Chrysemys concinna (Leconte).

Terrapene carolina (Linné).

Subsequent to 1862 but few incorrect records of West Indian species have been published. The following notes on four species show how all of these came to be credited to Grenada.

Anolis chrysolepis DUMÉRIL \& BIBRon.

Dumeril et Bibron, Erpét. gén., 1837, 4, p. 94 . Boulenger, Cat. lizards Brit. mus., 1885, 2, p. 89.

This species has been recorded from Grenada on the following grounds:-

Anolis nummifer and A. turmalis, described by O'Shaughnessy (Ann. mag. nat. hist., 1875, ser. 4 , 15, p. 278), do not appear from the description to be the same. Boulenger has included both in the synonymy of A. chrysolepis. This question is, however, beside the issue, since no individuals which agree with the description of any of the species come from Grenada, whence, however, the types of $A$. turmalis were said to have been collected. It seems very probable that a considerable collection from some South American mainland station was sent to the British museum labeled Grenada. The specimen of Plica plica (Linné) which Boulenger records from the same locality, is an exactly parallel case, and this specimen as well as one of Norops auratus probably came to the British museum at the same time.

This was written before the receipt of a letter dated November 6, 1911, 
in which Dr. Boulenger tells me that my surmise was correct; and that a collection from New Grenada (Colombia) got credited to the island of Grenada. This affects also the record for the following species.

Plica plica (LINNE).

Linne, Syst. nat., ed. 10. 1758, 1, p. 367. Bodlenger, Cat. lizards Brit. mus., 1885, 2, p. 180.

From New Grenada, not island of Grenada.

Norops auratus (DAUDIN).

Daddin, Hist. nat. rept., 1802, 4, p. 89. Boulenger, Cat. lizards Brit. mus., 1885, 2, p. 95.

A record having the same history as the preceding.

Gonatodes vittatus (LICHTENSTEIN).

Lichtenstein, Nomencl. reptil., 1856, p. 6. Boulenger, Cat. lizards Brit. mus., 1885, 1, p. 60.

The same history as the preceding. The record of this species from Dominica, needs verification, and is worthy of special mention in connection with the foregoing from Grenada.

Tropidodactylus onca (O'SHAJGHNESSY).

O'Shaughnessy, Ann. mag. nat. hist., 1875, ser. 4, 15, p. 280. Boulenger, Cat. lizards Brit. mus., 1885,2 , p. 97 .

The types of this species came from "Venezuela and Dominica." In answer to my query regarding the probable accuracy of the data for these lizards, Dr. Boulenger writes, "The Tropid. onca was purchased of a dealer (Mr. Cutter). The locality Dominica is therefore open to doubt." The species, thus, is obviously Venezuelan only.

Casual mention may also be made-of two records which Reinhardt and Lütken evidently overlooked, namely Testudo polyphemus and Cayman sclerops, which Gray recorded from Cuba (Ann. mag. nat. hist., 1840, 5, p. 115).

Anolis lineatus DAUDiN.

Dadorn, Hist. nat. rept., 1802, 4, p. 66, pl. 48, fig. 1. Bodlenger, Cat. lizards Brit. mus., 1885, 2, p. 38 . .

At various times this species has been reported from the Antilles. Duméril and Bibron (Erpét. gén., 1837, 4, p. 146) recorded it from Martinique. It is really confined to a region farther south. Meek (Field mus. publ. Zool., ser. 1910, 7, p. 416) records specimens from Aruba and Curacao. 
The case of this species is quite different from the others. Still it seems wisest to consider it here instead of in the list of certainly authenticated species.

Gymnophthalmus luetkenii BocourT.

Bocourr, Miss. sci. Mex. Reptil,, 1881, p. 474. BodLenger, Cat. lizards Brit. mus., 1885, 2, p. 429.

The type of the species was said to have been collected on St. Lucia by Bonnecourt, who sent a single specimen to the Paris museum. The specimens of this genus from St. Lucia reported by Garman and Boulenger all belong to G. pleii, so that it is probable that the locality of this type is incorrect. Nevertheless, the evident close relationship between the two species suggests that $G$. luetkenii will eventually be found on some other of the Lesser Antilles, unless indeed it exists in St. Lucia alongside of its congener. In this case, it must be very rare to have escaped capture by so excellent a collector as Garman.

In 1860 Cope described Scolecophis fumiceps (Proc. Acad. nat. sci. Phila., 1860 , p. 371) stating that the type was in the Museum of Comparative Zoölogy and that it probably came from Cuba. It probably did not come from Cuba, and I cannot find that the specimen which Cope borrowed was returned. Boulenger considers Cope's new species a synonym of Homolocranium planiceps, (cf. Cat. snakes Brit. mus., 1896, 3, p. 226).

\section{Ameiva bifrontata CoPE.}

Cope, Proc. Acad. nat. sci. Phila., 1862, p. 67.

This species was described from St. Thomas. It is confined to the mainland of South America. ${ }^{1}$ The type locality was the result of an error in labeling.

\section{INTRODUCED SPECIES. (FORTUITOUSLY OR OTHERWISE).}

Bufo marinis (LINNE).

Linnt, Syst. nat., ed. 10, 1758, p. 211. Boulenger, Cat. Batr. Sal. Brit. mus., 1882, p. 315.

A South American species which has been carried purposely to almost all the Antilles. We have it from Grenada, Barbados, St. Lucia, St. Kitts, Martinique, Nevis, Montserrat, and Jamaica, as well as from the Bermudas.

'The status of this species has just been fixed by Ruthven (Occas. papers, Univ. Mich. mus., Dee. 27,1913, no. 2, p. 1-3). 


\section{Hyla rubra DAUDiN.}

Daddin, Hist. nat. rain., 1803, p. 26, pl. 9. Boulenger, Cat. Batr. Sal. Brit. mus., 1882, p. 403.

This mainland species has been recorded from St. Lucia by Boulenger (Proc. Zool. soc. London, 1891, p. 354). It is probable that its introduction may have been accidental. Hylas are frequently carried about in shipments of living plants, and this case may easily be parallel to the finding of Hyla infrafrenata, a Papuan species, in the Botanical gardens at Buitenzorg, Java.

Hyla squirilla Bosc.

Diudin, Hist. nat. rain., 1803, p. 18, pl. 3, fig. 2. Boulenger, Cat. Batr. Sal. Brit. mus., 1882, p. 398.

The specimens from Stranger's Cay upon which the Bahaman record for this species rests have been reëxamined; and while they are not especially well preserved, there can be no doubt that they belong to this species. They do not show the markings so characteristic of the closely related $H$. femoralis, and the absence of web between the fingers precludes their inclusion in $H$. carolinensis. There can be no doubt regarding their artificial introduction, as was suggested when first the specimens were recorded (Barbour, Bull. M. C. Z., 1904, 46, p. 56).

\section{Constrictor constrictor LINNÉ.}

LinNé, Syst. nat., ed. 10, 1758, 1, p. 215. Bodlenger, Cat. snakes Brit. mus., 1893, 1, p. 117.

This mainland species occasionally reaches the southern Lesser Antilles, carried over on masses of flotsam and jetsam from the mouths of the large rivers of the mainland. Wallace (Island life, New York, 1881, p. 71) has said that "A large boa-constrictor was once floated to the island of St. Vincent twisted round the trunk of a cedar-tree, and was so little injured by its voyage that it captured some sheep before it was killed. The island is nearly two hundred miles from Trinidad and the coast of South America, whence it almost certainly came."

Such individuals have undoubtedly come to the islands once in a while since time immemorial, and yet never anywhere in the area has the species become established. Nor has any other species been proved to have been introduced and established by similar means.

For the use of the generic name Constrictor instead of Boa, consult Stejneger, Proc. U. S. nat. mus., 1902, 24, p. 185. 


\section{Hemidactylus mabouia (Moreat DE Jonnes).}

Moreau de Jonnes, Bull. Soc. philom. Paris, 1818, p. 138. Boulenger, Cat. lizards Brit. mus., 1885. 1, p. 122. Stejneger, Rept. U. S. nat. mus. for 1902, 1904, p. 599, fig. 40-45.

This gekko is quite in a class by itself with regard to its ease of establishment after accidental distribution. It has been found upon many of the West Indian Islands:- Cuba, Jamaica, Haiti, San Domingo, Porto Rico, St. Thomas, St. Croix, Just van Dyke, Tortola, Dominica, Sta. Lucia, St. Vincent, Barbados, Martinique, Petite Martinique, Mustique, Becquia, and Grenada. It is a widespread species carried from place to place in cargoes of wood and fruit. It is common on the Brazilian coast and elsewhere in South America, along the shores of East and West Africa, and Madagascar.

I procured a specimen on the wall inside a fisherman's house at the foot of Morro Castle, Havana, March 10, 1912. It was lying beside an oil light waiting for insect prey just as its relatives may so often be seen in the East Indies. I was told by the people that they never appear about electric lights as the glare is too strong.

Vague rumors are current upon all the West Indies concerning the occasional appearance of crocodiles upon their shores. From the following account it will be seen that this may happen, and perhaps does quite frequently. It is a very noteworthy fact that there has never been an establishment of any species in the Antillean region proper, except, of course, upon Cuba, Jamaica, and Haiti, where they were once very abundant and may still be found.

\section{Crocodilus intermedius Graves.}

Graves, Ann. gén. sci. phys., 1819, 2, p. 344. Boulenger, Cat. chelonians, etc., Brit. mus., 1889, p. 280.

What appears to be the only existing record for the capture of a crocodile in Grenada was secured by Dr. Allen during his visit. He reports that one came ashore on the east side of Grenada opposite St. George's, about 6 September, 1910, where it was seen on the beach by a negro. Later it was observed swimming between the beach and a nearby point of land, and a few days after was found dead on the beach. Its death occurred, unfortunately, while Dr. Allen was at work in another locality; and before he could secure the specimen, the teeth had been broken out by natives, and as the body putrefied on the shore, it was ordered buried by the local authorities. In its mutilated condition, however, it was photographed by a local photographer, Mr. Smith, who very kindly gave Dr. Allen a print. This shows at once the elongate, slender snout, almost 
gavial-like, which distinguishes Crocodilus intermedius from any other species on this continent. Boulenger (loc. cit.) says of this species that the largest known specimen measures nearly four metres. Mr. Smith, who measured the Grenada example, reported it as being 14 feet in length. It evidently came from the Orinoco, whence only this species could have come; and was probably carried by the strong westerly drift to the island. The most interesting and important observation to be drawn from this fortuitous occurrence is the fact that so strong and resistant a creature, aquatic at that, should not have been able to survive what would appear to have been a rather easy journey. No storm of special violence was noted, and crocodiles do not need to feed very frequently; yet this individual lived but a short time. This is one of the best actual observations bearing on dispersal by "flotsam and jetsam" that has been recorded by competent witnesses.

Col. Fielden, in the Zoologist (1888, p. 236; 1889, p. 298) records "the interesting fact of an alligator being transported alive on the trunk of a tree from the continent of South America to Barbados in 1886." There is no suggestion as to what species may have been represented.

Testudo denticulata LINNÉ.

Garman remarks that this tortoise "feeds readily in captivity, and is kept about the houses and carried from place to place much as the more common domestic animals." There are examples in the Museum from St. Lucia, St. Vincent, and a very large mounted example said to be from Porto Rico. It has also been reported from Cuba, upon several occasions. It is, of course, confined to South America in a wild state.

The three following Cuban records cannot be eliminated from the list with the same certainty that the foregoing West Indian records can.

Phyllobates bicolor BiBron.

Brbron, Sagra's Hist. Cuba. Rept., 1840, pl. 29, bis. Boulenger, Cat. Batr. Sal. Brit. mus., 1882, p. 195.

Gundlach, during his long residence in Cuba, never found this species. No specimen is to be seen in any of the local museums of Havana. Dr. Carlos de la Torre, a most enthusiastic and indefatigable collector and accurate observer, told me that he had never in his life-long collecting in Cuba been able to find an example. Since among the other collections sent to France by Ramon de la Sagra there were many examples which are now known never to have come from 
Cuba, it is almost certain that this record is based on a specimen from some other locality, probably Mexico. A number of the molluses which d'Orbigny described from Cuba in the same work have been shown to have been Mexican and n t Cuban.

Natrix anoscopa (COPE).

Cope, Proc. Acad. nat. sci. Phila., 1861, p. 299; Proc. U. S. nat. naus., 1892, 14, p. 673. Boulenger, Cat. snakes Brit. mus., 1893, 1, p. 242.

A Cuban species, the only Antillean representative of its genus. Cope compares it with $N$. cyclopion and $N$. rhombifera. Dr. Stejneger is inclined to believe that Cope had an African species. It is probably some species which by mistake got marked with an incorrect locality label. The evidence that Gundlach ever really found a species of Natrix in Cuba is very far from convincing. There is no Natrix of any species in the Museo Gundlach of the Instituto de Segunda Enseñanza in Havana.

Kinosternon baurii GaRMaN.

Garman, Bull. Essex inst., 1892, 23, p. 141. Siebenrock, Zool. jahrb. Suppl. 1909, 10, p. 442.

One of the types (M. C. Z., No. 4,050) of this species is said to have come from Cuba. It was mentioned at an earlier date by Garman; and was said to have been sent to the Museum, with much other Cuban material, by Filipe Poey (Proc. Amer. philos. soc., 1887, 24, p. 286). This is the only member of the family Cinosternidae which has ever been suggested to occur in the West Indies. On a visit to Washington, April, 1912, I saw in the United States national museum a specimen of Gerrhonotus! which was also said to have been sent from Cuba by Filipe Poey. Of course both these specimens may be victims of misplaced labels.

\section{ZOÖGEOGRAPHY.}

Instead of discussing the geographical distribution of the genera or species, it is more convenient to take up the fauna of each island or group of islands having a homogeneous biota; and then in a general survey, to draw some general conclusions regarding the main features of origin and dispersal of the fauna.

\section{Cuba.}

This island first claims attention because of many peculiar characteristics. It shows a far more intimate relationship with both North America and Central 
America than do any of the other islands. A few years ago it would have been considered unreasonable to assert that Cuba had been long and intimately related to Central America, and had certainly been for a shorter time connected with Florida or with the island which has since formed the region where Florida is now. Only in 1902 did Vaughan (Science, January 24, 1902, 15, p. 148-149) question the occurrence of remains of the fossil sloth Megalocnus in Cuba, even after the Cuban zoölogist, Dr. de la Torre had published his Observaciones geologicas y paleontologicas en la region central de la Isla [de Cuba]. In this paper the author recorded the finding of specimens at Cardenas, Sagua, and Santo Domingo, in addition to the type, which came from the now classic locality, Baños del Ciego Montero. Vaughan added, "I am not able to express an opinion as to the correctness of these localities or in Torre's ability to determine fossil vertebrates. I am inclined to doubt because there has been so much error regarding those fossils concerning which we have subsequently been able to procure definite data." As is now known, Dr. de la Torre has not only discovered well preserved remains of many individuals of Megalocnus; but he has uncovered besides the remains of a great fauna of rodents, edentates, and other mammals, as well as of tortoises and crocodiles. I have had the privilege of examining his collection in Havana; and de la Torre's final accounts of his discoveries will be awaited with the greatest interest. Suffice it to say that, stimulated by Vaughan's remarks, he has vindicated his previous statements with splendid success.

These finds, of course, prove Cuba's intimate relationship with the mainland; had they never been made, however, the proof offered by the existing genera of reptiles is equally convincing. In Florida Liodytes alleni has a nearest ally and possible progenitor in the Cuban species of Tretanorhinus. This genus occurs upon no other of the West Indies. In Florida, Rhineura, the only representative of the Amphisbaenidae in the United States, has possibly been derived from the ancestors of one of the two Cuban species of Amphisbaena. Although the genus Rhineura itself is an ancient one being known from the Miocene of South Dakota (R. hatcheri Baur). The occurrence in Cuba of Phyllobates, which is found upon no other island is very noteworthy. Tarantola cubana Gundlach \& Peters represents a genus occurring in the Mediterranean region of the Old World, and affords an interesting parallel to the occurrence of Spelerpes and Hyla pulchritineata Cope in Haiti. As yet, no urodele has been discovered in Cuba; and the allies of the Hyla mentioned are found in Mexico, the southeastern United States, and in the Old World, conspicuous among them being Hyla andersonii Baird, Hyla eximia Baird, and Hyla arborea Linné. 
The genus Chamaeleolis, with its single species, is autocthonous in Cuba, and the reason for its origin is not clear. Its nearest ally certainly seems to be Anotis equestris (Merrem) but it can hardly be derived from this species. The only West Indian species of Norops, found commonly on the island, again emphasizes the intimacy of its Central American relationship. Still more does the occurrence of Cricosaura typica Gundlach \& Peters. This rare creature, so far as known, is entirely confined to the small region about Cabo Cruz, and this closely circumscribed region has conditions very similar to those obtaining where the genus Xanthusia occurs. A Natrix has been recorded from this island alone of all the region; but the correctness of the locality of the typical specimen is open to grave doubt, and it is possible - perhaps even certain that it does not occur. Tretanorhinus has already been considered. Arrhyton is a curious autocthonous genus of which so few specimens are known that it is impossible to state whether the individuals that have served for the types of the three species recognized in Boulenger's Catalogue are really anything more than the widely varying individuals of a single species. The genus has probably been derived from some form similar to Contia, or some of its allies, from Central America. Urotheca dumerilii Bibron is supposed to come from Cuba; but no specimens have been taken there, so far as I can learn, since the discovery of the species; and it is probable that this species is Central American, as are all the others of the genus. The Cuban specimen in this Museum was sent by the Paris museum, and probably represents one of the original series. Crocoditus rhombifer Cuvier has its ally in Central America, where the species Crocodilus moreletii A. Duméril is so closely similar as to be almost indistinguishable. All the other Cuban species of reptiles and amphibians belong to genera which are found on other islands as well, though their distribution through the group varies. Hyla occurs in the Bahamas, in Cuba, Haiti, and Jamaica, and the Caymans; of Bufo, there are four species in Cuba, one in Haiti, and one in Porto Rico. Of these, Bufo empusus (Cope) represents the type which has extended most widely, being represented in Haiti by Bufo gutterosus Latreille, and in Porto Rico by Bufo lemur Cope. The Cuban species Bufo longinasus Stejneger, known from the type alone, is a form whose relationship cannot be made out from the material so far collected. Its only ally is Bufo ramsdeni described later in this paper. Bufo peltacephalus Tschudi is obviously of Central American origin.

Five species of Eleutherodactylus known for some time embrace three peculiar to the island, and two occurring elsewhere,-- one, E. recordii Duméril \& Bibron, occurring also in the Bahamas, and E. auriculatus (Cope) in Haiti and 
Porto Rico. A sixth species now described occurs apparently about Guantanamo only.

The distribution of the species of Gonatodes, Sphaerodactylus, Anolis, Liocephalus, Celestus, Ameiva, Amphisbaena, Typhlops, Epicrates, Tropidophis, Alsophis, and Leimadophis may all be found by referring to.the tables of distribution. The distribution of each of these genera includes Cuba, being represented there by peculiar island species, as is the prevalent mode of occurrence for these genera throughout that portion of the West Indies in which each occurs.

In conclusion, then, we may say that Cuba has sixty-three species of reptiles and amphibians, of which fifty are peculiar to the island. The proportion is probably larger than this, since a number of the records of Cuban species in Haiti will probably be found to represent distinct island races when comparisons of freshly collected and well-preserved material are possible.

\section{JAMAICA.}

No new species have been added to the fauna of Jamaica since I published my Notes on the herpetology of Jamaica (Bull. M. C. Z., 1910, 52, p. 273-302, pl. 1-2). Thirty-three species are recorded from the island; and of these, twentysix are peculiar. It is not necessary to go further into a special discussion of the Jamaican fauna, since I have nothing to add to the remarks in the paper referred to.

\section{Haiti and San Domingo.}

For the purpose of convenience these islands have been mentioned as Haiti throughout the paper; and, as the fauna in the two republics seems to be rather homogeneous, there is no special reason for not using this old Indian word, which was originally the name for the entire island.

From Haiti alone, of all the Antilles, has been reported a tailed amphibian,-Spelerpes infuscatus Peters, - and this fact, coupled with the occurrence of Hyla pulchritineata Cope, is significant of a relationship with the Mediterranean region, such as has already been suggested by Scharff. Besides the occurrence of these two anomalies, the fauna of Haiti is interesting as bearing out the belief that Cuba and Jamaica have never been joined together, and any similarity of fauna that the two islands show many be explained by the fact that each of them has at different times been connected with both Haiti and Central America. Thus the genera Bufo, Gonatodes, Liocephalus, and Amphisbaena are all found in Cuba and 
most of them in Porto Rico, while not a single one occurs in Jamaica. On the other hand, Aristelliger and Mabuya are found in Jamaica and Haiti, and the latter in Porto Rico, and neither in Cuba. These remarks refer to entire genera.

The distribution of certain species may be traced out in the same way. Thus Cuba has but one species of Celestus, while Jamaica has three and Haiti four, these four being the representatives of both the Cuban and Jamaican species. Broadly speaking, then, the Haitian species which have obviously been derived from the Central American mainland have come by two routes, the one the Cuba bridge, which undoubtedly endured for a considerable length of time, and which existed after and perhaps even came into existence after the disappearance of the connection between Jamaica and Haiti, since a number of Cuban genera and groups of species are found in Haiti and Cuba, but not in Jamaica; while a very small number of species derived from Haiti have representatives that passed to Cuba. Alsophis and Leimadophis occur on all three islands, but all the genera previously mentioned are confined to either pair of islands, always including Haiti, and not upon the third. The fauna is a large one, and embraces at least fifty-five species, for this number takes no account of any of the possible records for several species which are not absolutely authenticated. Forty-seven species certainly, and possibly others, are peculiar to the island. It will be seen from this, that, although a number of the continental genera occurring upon Cuba are not represented in Haiti, the total number of species found on the island is almost as great as that found upon Cuba, the difference being made up by those which have been derived through direct connection with Jamaica.

\section{PoRto Rico.}

Omitting special mention of Mona Island, which is not of great importance in the present connection, we may pass directly to a brief study regarding the fauna of Porto Rico. This has been very fully discussed by Stejneger in his Herpetology of Porto Rico (Rept. U. S. nat. mus. for 1902, 1904, p., 549-724).

Stejneger says (p. 562):-

"The herpetological fauna of Porto Rico falls into two groups, namely, the species which have in all probability originally extended their range from northeastern South America and those whose ancestors came from the west, primarily from the present mainland of Central America, and secondarily from the other Great Antilles."

The fauna of Porto Rico is less in number than that of either Cuba or Haiti; and is almost exactly comparable to that of Jamaica, there being twenty-six 
recorded species, of which two are of accidental occurrence, while fourteen are exclusively found upon Porto Rico; though a number of others, as Stejneger has shown, have but a circumscribed range, occurring on Porto Rico, and either Vieques, Culebra, or Mona Islands. Unlike either Haiti, Cuba, or Jamaica, Porto Rico has no genus of either reptiles or amphibians that is peculiar to it. This fact would seem to lend weight to the theory which has already gained some supporters, that the actual land area of an island has a certain more or less definite relationship to the species population of that island; and the larger the island is, the greater the number of genera and species that will be found on it. Cuba, the largest of the Antilles, and Haiti, the next largest, are in this way sharply set off from both Porto Rico and Jamaica, which are far smaller than either of the other islands, and more or less similar in size to each other. It is interesting to note that the same condition of affairs obtains in the East Indies, where Borneo, the largest island, has a greater number of species than Sumatra, which is geographically much more closely related to the mainland, and which might be supposed to have received probably a larger number of mainland types than any of the other islands.

The Virgin Islands.

Owing to the great depth of water found between this group and the rest of the Lesser Antilles, it might be supposed that a faunal boundary would be found to exist here comparable to that which was formerly supposed to exist in the East Indies between the islands of Bali and Lombok. This, however, is not exactly the case. Of the Central American genera which do not reach the Lesser Antilles, Hyla does not get to Porto Rico; Bufo reaches Porto Rico, but no further; Liocephalus extends to Haiti only; Celestus to Porto Rico. Amphisbaena, however, is found upon St. John, St. Thomas, and St. Croix; so that, while none of these genera extend so far as the Lesser Antilles, these islands form the limit of occurrence for only one of them; whereas the many characteristic Antillean genera of both reptiles and amphibians such as Eleutherodactylus, Sphaerodactylus, Anolis, Ameiva, Mabuya, Typhlops, Alsophis, and Leimadophis occur throughout the entire chain, without any reference whatever to a faunal boundary line between these islands. The group consists entirely of land masses of insignificant area, and with a correspondingly small number of species upon each island. 
The Lesser Antilles.

Although, generally speaking, the Lesser Antillean fauna may be said to be a very homogeneous one, certain anomalies of distribution appear which in some cases are extremely difficult to explain. At the present time the Fer-delance, Lachesis, occurs only upon Martinique and St. Lucia; but early voyagers wrote that the island of Petit Martinique received its name in their time on account of the abundance of the Fer-de-lance there. It probably at some time had a continuous distribution throughout the chain; but for some reason survived only on the two islands named. Other peculiarities are shown in the occurrence of Gymnophothalmnus on Martinique and St. Lucia; Constrictor orophias (Linné) on Dominica and St. Lucia, and possibly on St. Kitts. The peculiar distribution of Clelia, Pseudoboa, Drymobius, and Herpetodryas may be seen by referring to the table of distribution. Whether in some cases accidental introduction has been accountable for these distributions, or whether they have formerly been of wider occurrence and have died out on other islands, is a matter upon which it is hardly worth while to speculate since we will never know. Special mention, however, should be made of the fauna of Grenada, which is far more like that of Trinidad and South America than that of any of the other Lesser Antilles. Grenada is nearer Trinidad in point of distance than any of the other Lesser Antilles, except of course Tobago, which is not Antillean at all, but purely Trinidadian. This similarity in Grenada is not confined to those organisms which, by their capacity to stand immersion in salt water, or for some other reason, may be assumed to have come to the island fortuitously. It is a fundamental feature which is most evident in those types that we know are never carried from place to place by chance; and there can be but little doubt that Grenada has been connected with the mainland of northeastern South America more recently than have the other islands.

\section{Grenada.}

It is important in this connection to turn to the physical character of the Antilles. This has been well described in the following terms by Suess (Face of the earth, 1894,1, p. 544-545):-

"The Antilles may be divided into several zones.

"The first, innermost zone, which lies within the concavity of the arc, only appears in the eastern part, in the Lesser Antilles. It is wholly of recent volcanic origin. This zone is formed by the islands of Saba, St. Eustatius, St. Christopher (St. Kitts), Nevis, Redonda, 
Montserrat, the western half of the deeply incised Guadeloupe, Dominica, Martinique, St. Lucia, St. Vincent, the Grenadines, and Grenada. These islands form a continuous circular arc, and some of them include three to four eruptive centres - Martinique, according to Jonnès, even six.

"The next zone comprises the great and rich mountainous islands of the Greater Antilles and the narrow but well-characterized border of the Lesser Antilles. The mountains are formed in complete accordance with the type of the Coast Cordilleras of the south and of the mountains of Venezuela. The oldest organic remains belong to the lower Cretaceous, and these are only represented by a few traces; on the other hand, purer and highly fossiliferous limestone deposits of the Turonian are present in this region, as in Trinidad and in north Venezuela. The Cretaceous system is followed here, as in Trinidad, by a largely developed series of Tertiary deposits, some members of which present an astonishing resemblance to their representatives in Europe. These deposits form the connecting link with the third zone.

To this second group belong Cuba and Pinos Island, Haiti, Porto Rico, the Virginian Islands with St. Croix, Anguilla, St. Bartholomew, Antigua, the eastern half of Guadeloupe and a part of Barbados, and further the southern are which runs through Jamaica. That part which lies in the Lesser Antilles forms a girdle running outside the volcanos.

The third and outermost zone comprises only middle Tertiary or even more recent deposits. It nowhere rises in mountain ranges which can be properly so called, and is, indeed, as a rule, quite flat, broader towards the north-west, narrowing away to the south-east. It includes the Bahamas, all the banks of trifling height which succeed as far as Natividad, then Anegada, Sombrero, Barbuda, and a part of Barbados. I should, however, be inclined to include in this zone the whole peninsula of Florida, and perhaps even the level part of Yucatan.

"This regular arrangement of the islands was already clearly recognized in its main features by Leopold von Buch. 'All the volcanic islands of the Antilles,' wrote the great geologist more than sixty years ago, 'follow one after the other in a continuous chain, uninterrupted by any islands which are not volcanic. On the other hand, there appears to the east of these islands, lying outside them next the great ocean, another series of islands, somewhat less clearly marked, which exhibits only a few traces of volcanic phenomena, and contains no active volcanoes. This is an extremely remarkable fact!" "

From the above it will be seen that Grenada belongs to the first zone of islands, and is the most southern member of that chain. While Suess characterizes them as "wholly of recent volcanic origin," he can not mean that these islands arose from the sea, each independently, but rather that they represent in some cases each as many as four or six eruptive centres which have broken out along the mountain chain which made up the entire Greater and Lesser Antillean region.

The tilting into the Caribbean sea of Antillea, and the consequent slipping of the great, thick beds of which it was composed, may explain why each of the three concentric ares of islands has a homogeneous structure while it is still intimately related to the conformation and structure of the other two groups.

The composition of these arcs was briefly described above. In the inner group volcanos have arisen along the great joint plane, and have flowed out so as to overlie much of the older rocks, which nevertheless exist as the following quo- 
tation from Watts makes clear. Thus, their real core has been, in some cases, almost completely masked. The middle group is the dominant one, and has become thrust up in many cases to form mountain chains of considerable height, and to make all of the largest islands; while the outer series has given rise to only low-lying areas, some of them, however, of great size. Florida and some of the Bahamas, for instance, have a very considerable area.

Suess does not, however, give many facts as to the actual formation of each island, and the little information available is scattered far and wide in many journals. For Grenada there is no paper dealing with the geology which is in any way comparable to Guppy's Notes on a visit to Dominica, describing the geological features of the island (Proc. Sci. assoc. Trinidad, December, 1869, p. 377-392, $2 \mathrm{pl}$.). In view of this, the following quotation from an address published in the London times by Dr. Francis Watts, Imperial Commissioner of Agriculture for the West Indies, is of interest and importance:-

"A glance at the map of the West Indies almost certainly gives rise to the impression that the island represent the tops of a submerged land area, at one time connecting North and South America. Geologists support this popular impression, and refer to this lost country as Antillia, believing that it had an actual existence; but they are by no means agreed as to the period at which it was in being.

"Most of the islands bridging the gap across the Caribbean. Sea show marked volcanic characters. Thus if we consider the range from St. Thomas southward to Trinidad, we find the Virgin Island group, Saba, St. Eustatius, St. Kitts, Nevis, Montserrat, Guadeloupe (western half), Dominica, Martinique, St. Lucia, St. Vincent, the Grenadines and Grenada all considered as volcanic, while St. Croix, Anguilla, Barbuda, Antigua, Guadeloupe (eastern half), and Barbados are recognized as being built up extensively or entirely of sedimentary and coral rocks. The study of these latter has afforded grounds for assigning geological dates, more or less vague and tentative, to the various formations there found.

"It is generally assumed, though not perhaps very definitely stated, that the volcanic islands contribute little which will enable one to learn much of the past history of the chain of which they constitute so large a part - a view, which, coupled with a misunderstanding concerning the true nature of some of the rocks classed as volcanic, has impedded the advance of knowledge in no inconsiderable degree.

"Observations carried on for some time in the Island of Antigua have led to the conclusion that the so-called volcanic rocks of that island - rocks to which previous writers have referred as the oldest series, or the old igneous basement on which the latter series have been superimposed - have not the character accorded to them, but that they are highly altered and displaced portions of the sedimentary rocks which occur in an unaltered condition in the middle of the island.

"These unaltered sedimentary rocks, which have usually hitherto been wrongly described as tuffs, contain fossils in places, though these are not abundant. They consist of sandstones (often so fine-grained as to be mud stones) and conglomerates. Associated with these rocks are considerable masses of fossil wood completely silicified and in most instances so well preserved that the minutest structure is capable of examination in microscopic sections. In addition to these woods, there are associated with these rocks silicious masses containing 
shells of fresh and brackish water types in which, as in the case of the woods, the structure is often well preserved. These fossils should prove of value in determining the age of rocks, and it does not appear that up to the present they have received sufficient attention in this connection.

"It seems highly probable that these rocks are of similar age to the so-called "Scotland Series" of Barbados, and that they are of considerable geological age. As they underlie limestones, which geologists refer to Miocene times, they may well be of early Miocene or even Eocene age.

"The point now to be considered is that in the southwestern portion of Antigua these sedimentary rocks can be seen to pass into the series commonly described as volcanic, and to give rise to metamorphosed rocks connected with the sedimentary on the one hand, and the apparently volcanic on the other, the cause of this alteration being the intense activity which in later geological times, obliterated the traces of the continental sedimentary areas and substituted the volcanic masses of such islands as St. Kitts, Nevis, Montserrat, and Dominica.

"With the clue afforded by the study of the Antigua rocks it seems possible to detect traces of the old continental sedimentary areas in several of the islands hitherto regarded as purely volcanic. In this manner, rocks which are probably of sedimentary origin may be found in St. Lucia, where it is interesting to note that small quantities of fossil wood, apparently similar to some of the fossil wood of Antigua, has been found in association with them.

"Again in Grenada, an island hitherto described as entirely volcanic, more or less altered rocks of an apparently sedimentary character have been seen, and it is said that small quantities of limestone are associated with these. If this latter fact is verified, it may link up this series with those of Antigua.

"The geologically unexplored Grenadine islets, lying between Grenada and St. Vincent, may afford evidence of these hitherto unsuspected stratified rocks and may add to the story of the old Antillean continent. The forms assumed by their weathering suggest in places sedimentary rather than volcanic rocks, as do also some of the outlines of parts of Grenada itself.

"These now nearly obliterated sedimentary rocks occurring as the Scotland Series of Barbados, the so-called tuffs of Antigua and in a few other parts of the West Indies between Trinidad and the Virgin Islands were probably derived from, or may have constituted part of, the old Antillean continent. A careful study of this formation, coupled with the recognition of its wider distribution than has been hitherto recognized, may be useful in determining the age of that continent, which will probably be found to belong to the Eocene period.

"The object of these notes is to draw attention to the fact that there exists in the West Indies many plainly indicated, but imperfectly studied, geological problems offering attractions to geologists and promising fair harvests of results. Much has been done by various observers to indicate the general lines of research, but now the details require to be filled in. It would seem that Antigua offers, perhaps, the best starting point for studies such as are here indicated; after working out the problems of Antigua, those of Guadeloupe and St. Croix would probably be readily solved. After this, it would seem possible to unravel the difficulties presented by the volcanic islands, and for this purpose a detailed study of Grenada, the Grenadines, St. Vincent and St. Lucia would doubtless indicate the line of attack. It is thus evident that, to geological students wishing to combine pleasant travel with interesting work, these islands offer many attractions and some opportunities of gaining recognition for discoveries of interest.

"Such students, should they come, will find in most places plenty to engage their attention, and kindred spirits willing to direct their inquiries into useful channels without loss of time, and one would view with pleasure and appreciation the formation of a small expedition 
composed of students qualified for field work, under a competent senior, who would visit the West Indies for a course of post-graduate study, and would look forward to the acquisition of results of considerable scientific interest and value."

That the general process of island formation has been extremely slow, and that the evolution from a great land mass of almost continental size and perhaps Eocene age, to the present condition of an extensive archipelago took place evenly and without any great regions disappearing below the sea to reappear later, is shown by the distribution of the land animals. These do not appear now to fall into series corresponding in their distribution to the island ares, but taken altogether form a single, remarkably homogeneous fauna, many characteristic features of which may be traced from Cuba or Jamaica to Grenada. Naturally types derived from Central America predominate in Cuba and in Jamaica (Barbour, Bull. M. C. Z., 1910, 52, p. 276), as naturally types derived by the connection with northern South America predominate in Grenada; while in Porto Rico, for example, the fauna is mixed as one would expect it to be. In times past, great stress has been laid on the significance of the great deep in the Virgin group which separates these islands from St. Croix by 2,000 fms. Nevertheless, the same rocks reappear on both sides of the cleft, and the distribution of the fauna shows that this cleft has not always existed. Such a deep of limited area between two land masses lying unaffected by it and yet so near at hand, has, by the fact of its depth alone, but little significance. The phenomenon of islands with closely related faunae being separated by a small area of very deep water is met with frequently in all parts of the world. In the East Indies the Ké Islands are connected on the one hand with Ceram by a series of shallows, reefs, and islands; while, so far as is known, only deep water exists between the Ke and Aru groups and Papua. The fauna in Ké shows many Papuan types as well as types derived from Ceram. Such deeps as these are in no wise to be confounded with extensive clefts like that between Jamaica and Cuba, or between Borneo and Celebes. These are very real zoölogic boundaries which have existed since the dawn of land life on the earth. Their importance is pointed out especially by the fact that, although they are narrow, yet no interchange of fauna whatever has taken place across them by "flotsam and jetsam" methods of dispersal. Yet animals should float across these straits as easily as across great stretches of oceans; and this, some writers persist in believing, constantly occurs. Eduard Suess in 1893 contributed a very enlightening article to Natural science $(1893,2$, p. 180-187) having the title Are great ocean depths permanent? 
In 1910 when I published my Notes on the herpetology of Jamaica, I quoted Dr. R. T. Hill as believing that the West Indies "have persisted without Continental connection or union with each other since their origin." He wrote this after the publication of his Notes on the geology of the island of Cuba (Bull. M. C. Z., 1895, 16). I find however by re-studying his Geology of Jamaica that after his more prolonged examination of the geology of Jamaica he changed his opinion very radically, for here (Bull. M. C. Z., 1899, 34, p. 224) he says:-

"In late Oligocene or Miocene time there was a tremendous orogenic movement which resulted in uplift, whereby many of the islands were connected with each other, and possibly an insular southern portion of Florida, but not establishing land connection with the North and South American continents.... In Miocene or early Pliocene time the islands were severed by submergence into their present outlines and membership, which they have since retained with only secondary modification."

It will be seen that these views agree more closely with the conclusions which are forced by an interpretation of the facts presented by the distribution of existing animals. The Lesser Antilles have probably been subject to more violent disturbances than the Greater. Nevertheless the existing species show that nearly all of the islands if not every one of them, has never been completely submerged since their original breaking away from the land which now forms northeastern South America, or more probably that part of it which is represented in remnants by the great flat-topped mountains such as Roraima in British Guiana. Grenada and possibly some of the other more southerly Lesser Antilles have probably been in temporary union with the mainland once or twice since the first connection was severed.

Regarding the origin and affinity of the Grenadian fauna, then, we may summarize by saying that in its salient features it is a typical Antillean island fauna. It shows closer affinity with South America than the other islands to the northward. It has evidently been connected with South America after it became separated from St. Vincent and the other islands north of it; and this separation may have been caused by subsidence, accompanied by a slow folding which began north and progressed to the southward, separating the islands successively from one another. This is suggested by the progressive diminution of typical South American forms from south to north. The geological structure of many of the islands of the inner Antillean are is so masked by the products of extensive and recent volcanic activity that the zoölogist can look for but little assistance from the geological investigation of these islands. Their past history will only be definitely known when the land fauna of each island is completely investigated. 
The introduction of the mongoose has, in Grenada as elsewhere, resulted in marked changes affecting the relative abundance of many animals, and none have suffered more than the reptiles. In writing of several species, I have included notes furnished me by Dr. Allen regarding mongoose ravages. I have previously had something to say regarding the conditions in Jamaica, and there as in Grenada, the same genera seem to have suffered most from the introduction of this pest (Barbour, Bull. M. C. Z., 1910, 52, p. 270-301).

\section{CONCLUSIONS.}

The fauna of the West Indian region as a whole is homogeneous; that is to say, certain genera, as for instance Ameiva, probably derived from northeastern South America, have penetrated through the chain with a local species upon practically every island, and reached as far as Cuba and Jamaica. Naturally, the types derived from South America are most abundant in the islands which were last in connection with South America, as in Grenada; and disappear gradually, dropping out one by one, until but comparatively few reach the Greater Antilles. Conversely, types of Central American origin predominate in Cuba and Jamaica; Central American types, derived through both of these islands, occur on Haiti and Porto Rico. Other genera which may be called purely Antillean are found throughout the entire group of islands; and the most characteristic of these are Alsophis and Leimadophis, whose distributions parallel one another in a most remarkable manner, as does also the distribution of Eleutherodactylus. There is no use in expanding upon the limits of extent of the other genera, as these may easily be seen by referring to the tables. The point, however, which is most worthy of emphasis is that this homogeneous fauna is characteristic not only of reptiles and amphibians, but of birds and mammals, as well as of groups of terrestrial invertebrates, Peripatus affording an excellent example. When this fact is taken into consideration with the regularity with which the important genera occur on practically every island that has been scientifically explored, with a species peculiar to each, it becomes evident at once that these groups of individuals on each island have been isolated for a long time, and that evolution by isolation would be impossible if individuals were being carried from one island to another by flotsam and jetsam dispersal. The inherent tendency of any isolated group of individuals to vary in some definite direction and to fix peculiar characters within the group would be impossible if a constant 
exchange of individuals from one island to another were taking place. If this has taken place in the past, it should be occurring still; and the fact that it does not occur now is good proof that this method of dispersal has never played a part of any importance in the past. A very few species have been carried about fortuitously, - whether by human agency or otherwise, it is impossible to know, - but this has been the exception and not the rule. The West Indian fauna is obviously one which has descended from species which formerly ranged over great areas of land which, in connection with each other at various times, as well as with the mainland of Central and South America, have gone to make up the area we may call Antillea. 


\section{ANNOTATED LIST OF THE SPECIES.}

AMPHIBIA.

Spelerpes: infuscatus Peters.

Peters, Monatsb. Akad. wiss. Berl, 1879, p. 778. Bodlenger, Cat. Batr. Grad. Brit. mus., 1882, p. 72.

In speaking of the type, Peters says: "Auch von dieser Art besitzt das Museum nur ein einziges Exemplar (No. 6556), durch das Museum Godeffroy aus Hayti erhalten."

No discovery has ever been made in the West Indian region that surpassed in zoögeographic importance the finding of a salamander upon Haiti. Taken in connection with the distribution of Spelerpes fuscus (Bonaparte) in Italy and southern France, it is one of the suggestions that there may have been an ancient connection between southern Europe and Antillea. Mr. Mann who collected in Haiti (November, 1912-February, 1913) did not succeed in finding this species, although he searched especially for it.

Hyla septentrionalis BoULENGER.

Bodlenger, Cat. Batr. Sal. Brit. mus., 1882, p. 368.

Stejneger (The Bahama Islands, 1905, p. 330) states the reasons for crediting this species "to Boulenger. It is found commonly upon Cuba and among the northern Bahama and Cayman Islands. I have examined the type of Hyla wrightii Cope in the U.S. national museum, and can state positively that it is a synonym of this species. The type of Hyla insulsa Cope has been lost. From my variable series collected near Cienfuegos, Madruga, Matanzas, Havana, Herradura, San Diego de los Baños, Pinar del Rio and Guantanamo, I have no doubt but that this species is a synonym also.

Hyla vasta COPE.

Cope, Proc. Acad. nat. sci. Phila., 1871, p. 219. Bodlenger, Cat. Batr. Sal. Brit. mus., 1882, p. 351.

This enormous species, one of the very largest in the genus, was among those found by Gabb while he was in charge of the Geological survey of San Domingo. It is apparently very rare, since its great size would render it noticeable if it were at all common, to say nothing of its probably sonorous voice, which must be farsounding. Cope remarks that in structure it appears to resemble Hyla lichenosa 
Günther of Mexico. Boulenger, however, says that this species is a composite one which may be resolved into $H$. venulosa (Laurenti) and $H$. nigropunctata Boulenger; although just why Günther's name is not available for this last species is not quite evident (Cat. Batr. Sal. Brit. mus., 1882, p. 364, 366).

Hyla dominicensis (TschUDI).

Tschudi, Class. Batr., 1838, p. 30. Boulenger, Cat. Batr. Sal. Brit. mus.; 1882, p. 370 (part).

In my Notes on the herpetology of Jamaica (Bull. M. C. Z., 1910, 52, p. 289) I showed how this species differed from Hyla brunnea Gosse of Jamaica, and also remarked that a comparison of a large series from Haiti and San Domingo with the type of Cope's H. ovata (M. C.Z., No. 1,518) showed them to be one and the same species. The species is confined to Haiti, whence the Museum has many specimens from all parts of the island.

\section{Hyla brunnea Gosse.}

Gosse, Naturalist's sojourn in Jamaica, 1851, p. 361. BArbovr, Bull. M. C. Z., 1910, 52, p. 288.

Although a number of species of the genus Hyla have at one time or another been either described or recorded from Jamaica, there can be no doubt but that this form and Hyla lichenata (Gosse) are the only ones that really occur there. This species is common, is confined to the island, and takes there the place of $H$. dominicensis (Tschudi) in Haiti and H. septentrionalis Boulenger in Cuba.

Hyla lichenata (GossE).

Gosse, Naturalist's sojourn in Jamaica, 1851, p. 362, pl. 7. BARBour, Bull. M. C. Z., 1910, 62, p. 289.

A curious and apparently very rare species, confined to Jamaica.

Hyla pulchrilineata Cope.

Cope, Proc. Amer. philos. soc., 1869, 11, p. 163. Boulenger, Cat. Batr. Sal. Brit. mus., 1882, p. 378

The beautiful little tree-frog first discovered by Gabb in San Domingo is represented in the collection by a fine specimen taken at Puerto Plata, San Domingo, by Mr. M. Abbott Frazar. The species is confined to the island, and is the only West Indian Hyla that is not referable to the section Trachycephalus. Its origin and relationships provide a fruitful field for speculation, and many be said to provide a parallel to the very unexpected discovery of Spelerpes in Haiti, since it is a not very distant relative of the widespread European Hyla arborea (Linné). 
Bufo longinasus STEJNEGER.

StejNeger, Proc. U. S. nat. mus., 1905, 28, p. 765.

The type alone is known (U.S. N. M., No. 27, 419) of this remarkable little toad, quite unrelated to the other Antillean members of the genus. It was captured at dusk on a rock in a mountain stream near El Guamá, in the Province of Pinar del Rio, western Cuba, by Messrs. William Palmer and J. H. Riley, during their extensive collecting trip of 1900. Naturally nothing is known of its habits, or distribution. The fully webbed hind feet indicate that its habits are probably more strictly aquatic than the others of the genus in Cuba. Thanks to a note of Mr. William Palmer I was able to collect at about the exact type locality, but unfortunately I was unable to find a single specimen.

Bufo ramsdeni, sp. nov.

Type:- No. 3,213, M. C. Z., one specimen, Los Hondones, Monte Libano, Guantanamo, Cuba. June, 1913, C. T. Ramsden, collector.

This beautiful species requires comparison with Bufo longinasus Stejneger only. It differs in having the toes but little webbed, the fingers longer, in having more numerous dorsal tubercles and a very strikingly different coloration.

Head and body depressed; snout concave along median line, projecting and rather pointed; canthus rostralis rounded; interorbital space much wider than upper eyelid; tympanum scarcely visible; first finger shorter than second; tips of fingers and toes not dilated and hardly swollen at all; fingers slender, longer than in $B$. longinasus; toes slightly webbed; subarticular tubercles large, single; both metatarsal tubercles well developed; a tarsal fold; tibiotarsal articulation of adpressed hind limb reaches midway between insertion of fore limb and tympanic region; skin itself smooth, with small wrinkles and many tubercles arranged in more or less regular longitudinal series; paratoids greatly developed as in Bufo longinasus. Color (in alcohol) above almost black, a conspicuous light stripe from snout to vent, this stripe is extended laterally on the eyelids and thus widens to a rhomb-like figure on the head. The light stripe is bordered on each side by a narrow band of deep velvety black. Below, the throat is mahogany-brown, the fore part of chest and angles of the jaws deep brown; the belly is white profusely spotted and streaked with dark brown, as are also the lips and upper surfaces of the limbs.

The type and only known specimen of Bufo longinasus is a male; B. ramsdeni while almost the same size is a female with the sexual organs decidedly 
immature. It is, however, hardly conceivable that the marked differences which they exhibit can be explained on the basis of sexual dimorphism. If this should turn out to be the case it would be unique in the genus. I prefer to believe that there are two related species representing this remarkable section of the genus, probably as in so many other species, one confined to the western region and the other to the eastern. The differences having arisen in these cases probably not so much through isolation as through the extremely different environmental conditions.

I have named this remarkable species for its discoverer, my hospitable friend Mr. C. T. Ramsden, of San Carlos, Guantanamo.

The stomach of this specimen was filled with partially digested ants and small beetles. The locality whence it came is at a considerable altitude above sea level. The type of $B$. longinasus came from a lowland stream.

Bufo peltacephalus Tschudr.

Tschudi, Class. Batr., 1838, p. 52. Boulenger, Cat. Batr. Sal. Brit. mus,, 1882, p. 325.

Boulenger cites p. 89 of 'Tschudi's work as the original description. This refers to a nomen nudum only; the short description, which is, nevertheless, perfectly recognizable, is with many others intercalated in the general discussion of the Bufonidae.

This is the most widely distributed of the four species of toads known from Cuba. The Museum has specimens from Pinar del Rio, San Diego de los Baños, Havana, Guantanamo, and Santiago de Cuba. All four of the species are confined to Cuba.

The theory that the West Indian toads are a disappearing group is not entirely tenable. This species and Bufo empusus exist in large numbers, although their appearance is extremely erratic, almost comparable to that of Scaphiopus in the eastern United States. Once their mode of hiding becomes known, they may be obtained easily. About Pinar del Rio this species excavates a deep burrow under a loose rock, and by turning rocks they may often be found. In other places, they live about houses, especially in the mouths of the rain-water drains. They are often seen moving about at night, their sallies being apparently far more frequent than those of Bufo empusus.

Bufo gutturosus LATREILlE.

Latreille, Hist. nat. Rept., 1802, 2, p. 135. Boulenger, Cat. Batr. Sal. Brit. mus., 1882, p. 324.

Upon comparing an adult toad from Haiti with a Bufo lemur Cope, the 
characters that Stejneger (Rept. U. S. nat. mus. for 1912, 1904, p. 570) pointed out as likely to be diagnostic are found, just as he suspected. Stejneger had no Haitian specimen; but his conclusion, based on the evidence of previous descriptions and figures, is confirmed by the material available here.

It is said to be common locally but to be very erratic in its appearance. Mr. Mann collected specimens at Cape Haitien, Diquini, Momance, Manneville, and Grand Riviere. I have seen no examples from the San Domingo end of the island.

This species, then is confined to Haiti, being replaced on Porto Rico by its ally Bufo lemur Cope.

\section{Bufo lemur Cope.}

Cope, Proc. Acad, nat. sci. Phila., 1868, p. 311. Stejneger, Rept. U. S. nat. mus. for 1902, 1904, p. 570 , fig. 1-5.

As Stejneger surmised, this toad is quite distinct from the Bufo of Haiti, and hence is confined to Porto Rico, where it is very rare. Stejneger heard reports of its occurrence on Vieques Island, but was unable to obtain any specimens. August Stahl, the venerable Porto Rican naturalist, told Stejneger that he himself had never once found the "sapo concha," as it is called by the Spanishspeaking natives. In forty years only six specimens had come into his possession, brought in by peasants who found them by chance. Of these, two are now in the collection of the Museum (M. C. Z., No. 2,180).

I can not do better than to quote verbatim Stejneger's account of how he finally succeeded in procuring specimens near Arecibo:-

"We made diligent inquiries in the neighborhood through our young friend Mr. Enrique L. Brascoechea, and finally, as we had almost given up hope, he found an old beggar who remembered a place where as a boy he had seen the sapos. He was promised a substantial reward, and on the last evening of our stay in Arecibo brought in five fine specimens captured about 3 miles south of the town. He said he had found them in holes under the roots of palm trees at the border of a fresh-water pond, where they kept in hiding during the day."

\section{Bufo empusus (Cope).}

Cope, Proc. Acad. nat. sci. Phila., 1862, p. 344. Gundlach, Erpet. Cubana, 1880, p. 87. Boulenger, Cat. Batr. Sal. Brit. mus., 1882, p. 326.

Gundlach found this species, so rare in collections, rather common locally in the Cienago de Zapata, in the jurisdiction of Colon, in the savannas near Los Ciegos, and Los Palacios in the Vuelta Abajo region of the Province of Pinar del Rio. I was able to obtain a splendid series in some plains about five miles northeast of Herradura, also in the Province of Pinar del Rio. I should 
never have learned of their existence had it not been for the aid given me by an intelligent young Cuban, Sr. Lucio Alfonso. In response to my inquiry regarding the occurrence of the "Sapo de Concha," he took me to an upland clayey pasture near by, which had recently been burned over. Scattered thickly over this whole area were the mouths of a great number of small burrows. These were evidently of two sorts, for the openings of some were carefully rimmed with smoothly patted clay, while the others were rough and looked unfinished. Those with the rims each contained a Bufo empusus. The tube-like burrow was perfectly cylindrical and from seven to ten inches deep. The toad which always looked larger than the diameter of the burrow, was to be found in a small chamber at the bottom, its curious hornlike, shelly, head forming an operculum which closed the burrow accurately. To accomplish this closing most advantageously, the toad was sometimes found resting on its side or back. The small individuals were frequently observed near the surface, their little heads just filling the mouth of the tubes. Only one or two adults were observed near the surface. The other burrows spoken of were inhabited by Tarantulas, which were excessively common.

Gundlach says, and he is confirmed by what the country folk told me, that these toads come forth to sing in unison on warm nights after a rain. There is no apparent rule to guide their appearance and they are not heard during many apparently favorable nights. The people told me that they had never met them outside their burrows, probably because they had not visited this particular field by night. From what I have heard, I am sure this species always occurs in these colonies in areas where the soil is suitable for making their burrows.

Eleutherodactylus ricordii (DUMÉRIL ET BiBRoN).

Duméril et Bibron, Erpét. gén., 1841, 8, p. 623. Boulenger, Cat. Batr. Sal. Brit. mus., 1882, p. 213.

A common species throughout Cuba and the northern Bahama Islands. It has been taken in Florida, and seems to be spreading northward (Barbour, Proc. Biol. soc. Wash., 19i0, 23, p. 100).

In 1887 Cope admitted that his Hylodes planirostris was synonymous with this species (Proc. U. S. nat. mus., 1887, 11, p. 406). There seems, however, to be a tendency for Cuban examples to have a shorter fourth toe than Bahaman individuals. This difference does not appear to be an invariably constant character. 
Eleutherodactylus dimidiatus (COPE).

Cope, Proc. Acad. nat. sci. Phila., 1862, p. 151.

This distinct species from eastern Cuba was overlooked by Boulenger when he was preparing the Catalogue of Batrachia Salientia in the British museum, 1882. There are several specimens in the U. S. national museum, which I have examined. While in $1913 \mathrm{I}$ found it at a point near Pozo Prieto, Barrio of Los Negros, Jurisdiction of Jiguani and Mr. V. J. Rodriguez secured it at the Pan de Azucar also in the Sierra Maestra.

Eleutherodactylus cuneatus (CoPE).

Cope, Proc. Acad. nat. sci. Phila., 1862, p. 152. Bodlenger, Cat. Batr. Sal. Brit. mus., 1882, p. 209.

This little frog was among those sent to the Museum by Major Wirt Robinson, U. S. A., from Santiago, Cuba. The species was first described from eastern Cuba. In February, 1912, I found a single typical example near Cienfuegos The U. S. national museum has specimens from several localities in Pinar del Rio, collected by Palmer and Riley.

Eleutherodactylus plicatus, sp. nov.

Type:-No. 3,056, M. C. Z., an adult, La Union, Monte Libano, Guantanamo, eastern Cuba, March 23, 1913, C. T. Ramsden, collector.

The type of this peculiar species, the sixth of its genus to be observed in Cuba was sent to the Museum with specimens of $E$. dimidiatus and $E$. ricordii from the same locality.

In its habit it reminds one of $E$. cuneatus but it differs strikingly in the shape of the head, which is much more rounded in front, in the remarkable dorsal rugosity, in the position of internal nares and vomerine teeth and in the absence of the characteristic black inguinal markings.

Tongue medium, oral, entire behind; vomerine teeth in two long series which converge posteriorly and almost meet at the median line, extending laterally but very little beyond the choanae which are situated nearer the median line than in the other species; head broad and rounded; snout only slightly declivitous; nostrils much nearer tip of snout than eye; upper eyelids slightly less wide than interorbital space; tympanum medium sized and round about one half the diameter of the eye; its distance from the latter equal to its own diameter; fingers with exceedingly small dises, the first and second fingers are equal in length; first toe much shorter than second; subarticular tubercles well 
developed; no marked plantar tubercles; a rather small inner and outer metatarsal tubercle; a feebly developed tarsal fold, which may be due to shrinkage; hind limbs being bent forward along body the heel reaches beyond the tip of the snout, bent vertically to the axis of the body they overlap considerably; skin above extremely rugose and plicate; throat, chest, and anterior aspect of thighs perfectly smooth, belly and posterior femoral aspects finely granular.

Color of freshly preserved example. Uniform olive-brown above, below all surfaces a beautiful roseate pink, front of thighs more brilliant pink, throat with a few dark dots.

I am very loath to add a species to this multitudinous genus on the basis of a single specimen. Nevertheless this specimen is so peculiar in many ways that I am unable to include it in any known species. At first I thought that the dorsal rugosity was an artifact of preservation, as the other specimens taken at the same time and place, show no signs of this peculiar condition. It is a very slender and elegant form, beautifully colored and probably, localized' in eastern Cuba, as, for instance $E$. unicolor Stejneger is confined to El Yunque in Porto Rico.

Eleutherodactylus varians (GUNDLACH \& PÉTERs).

Gundlach \& Peters, Monatsb. akad. wiss. Berlin, 1864, p. 390 . Boulenger, Cat. Batr. Sal. Brit. mus., 1882 , p. 215.

A Cuban species which is next to $E$. ricordii, the most abundant and widely distributed species in central Cuba. We collected a large series about Soledad, near Cienfuegos during February, 1912. I have never found this species in Oriente.

\section{Eleutherodactylus luteolus (GossE).}

Gosse, Naturalist's sojourn in Jamaica, 1851, p. 366, pl. 7. Bodlenger, Cat. Batr. Sal. Brit. mus., 1882, p. 208. BARBơr, Bull. M. C. Z., 1910, 52, p. 286, pl. 2, fig. 1.

A very interesting and abundant species, confined to Jamaica. The metamorphosis from egg to adult is direct, the frothy egg-mass being laid in a depression in moist earth; the period of incubation is very short.

Eleutherodactylus jamaicensis BARBour.

Barbour, Bull. M. C. Z., 1910, 62, p. 287, pl. 2, fig. 2.

A rather rare species, which I had supposed was confined to the highlands about Mandeville, Jamaica. Recently, however, Mr. C. T. Brues, has brought back a beautifully preserved specimen from Newton, Jamaica. 
Eleutherodactylus weinlandi, sp. nov.

Type:- No. 2,050, M. C. Z., an adult, Puerto Plata, San Domingo, December, 1881, M. Abbott Frazar, collector.

The type of this distinct new species is the one that Garman recorded from Puerto Plata as Hylodes lentus (Bull. Essex inst., 1887, 19, p. 14). It is related to $E$. richmondi Stejneger of Porto Rico, and through it to E. lentus of St. Thomas. In some characters it suggests $E$. jamaicensis; and these species together probably form a natural series through the Greater Antilles as $E$. auriculatus, E. martinicensis, and E. johnstonei do in both the Greater and the Lesser Islands. The migration of the first group took place after, and of the second group before, the opening up of the deep passage through the Virgin Islands.

Tongue rather narrow, slightly emarginate behind; vomerine teeth groups meeting to form a continuous $\sim$-shaped series behind the choanae, there is no space between the series and the choanae, but the series extends laterally beyond the choanae almost to a line with the margin of the jaws; nostril much nearer tip of snout than eye, the distance from the eye being equal to its diameter. Tympanum slightly less than one half the diameter of the eye, its distance from the latter about equal to its diameter; dises of fingers small; first toe short, only reaching the subarticular tubercle of the second; subarticular tubercles well developed; two well-developed metatarsal tubercles; no plantar tubercles; no tarsal fold; the bent limbs being pressed along the sides, the knee and elbow meet; hind limb being extended along the side, the heel reaches the centre of the eye; hind limbs being placed vertically to the body-axis, they overlap; skin above and on the flanks very finely granular; underside smooth; posterior border of thigh areolate.

Color, spirit specimen: dorsum dark brown, a light line on each side beginning at the nostril, running through the eye, and ending in a light area which covers the sacral region. Limbs, except hinder side of thigh, and belly light and immaculate. The sacrum and hind limbs appear to have been red in life. Garman states that they were so, but evidently by inference also.

This species is named to commemorate the work of Dr. D. F. Weinland, whose indefatigable collecting on this island greatly increased our knowledge of Antillean herpetology.

In the collection made by Mr. W. M. Mann there is an immature example from Diquini, Haiti, which seems to be referable to this species. 
Eleutherodactylus richmondi STEJNEGER.

STEJNeGER, Rept. U. S. nat. mus, for 1902, 1904, p. 593, fig. 25-29.

A species related to $E$. lentus (Cope), but confined to the region near the summit of El Yunque Mountain, Porto Rico.

Eleutherodactylus lentus (COPE).

Cope, Proc. Acad nat. sei. Phila., 1862, p. 151. Boulenger, Cat. Batr. Sal. Brit. mus, 1882, p. 207.

This species is confined to St. Thomas. The specimen from Puerto Plata, San Domingo, recorded by Garman, (Bull. Essex inst., 1887, 19, p. 14) does not belong here, but to $E$. weinlandi now described as new. Boulenger also includes San Domingan examples under this species, but these in all probability may also be referred to $E$. weinlandi Barbour.

Eleutherodactylus unicolor STEJNEGER.

SteJNEGER, Rept. U. S. nat. mus. for 1902, 1904, p. 597, fig. 35-39.

A very peculiar species, confined to El Yunque Mountain, Porto Rico. Stejneger remarks that it has no near relation in all the Antilles.

Eleutherodactylus monensis (MEERWARTH).

Meerwarth, Mitth. naturh. mus. Hamburg., 1901, 18, p. 39, pl. 1, fig. 11; pl. 2, fig. 4-5. Stejneger, Rept. U. S. nat. mus. for 1902, 1904, p. 595, fig. 30-34.

A species confined to Mona Island.

Eleutherodactylus auriculatus (COPE).

Cope, Proc. Acad. nat. sci. Phila., 1862, p. 152. Stejneger, Rept. U. S. nat. mus. for 1902, 1904, p. 583, fig. 15-19.

Having specimens of $E$. martinicensis (Tschudi) from several of the Lesser Antilles, - among them St. Kitts, Martinique, Monserrat, and Guadeloupe, I can confirm Stejneger's statement that this Greater Antillean form well merits separation. It is known from eastern Cuba, the type locality, San Domingo, and Porto Rico. Mann's single example from Grand Riviere, Haiti, appears to have the tympanum slightly larger than is shown in Stejneger's figure.

Eleutherodactylus antillensis (REINHARDT \& LÜTKEN).

Reinhardt \& LÜtKen, Vid. Meddel. nat. foren. Kjöbenh., for 1862, 1863, p. 209. Stejneger, Rept. U. S. nat. mus. for 1902,1904 , p. 591, fig. 20-24.

A species which Stejneger has shown to be perfectly distinct from $E$. auriculatus, with which Boulenger had previously united it. 'It is definitely known 
only from St. Thomas and Vieques. It may occur upon St. Croix and St. John, but there is no definite record for these islands.

Eleutherodactylus martinicensis (TsCHUDi).

Tschudi, Class. Batr., 1838, p. 77. Boulenger, Cat. Batr. Sal. Brit. mus., 1882, p. 214 (part).

This famous little frog, so easily and so often carried from place to place, is now very widespread in the Antillean region. Although this species develops without metamorphosis by skipping a free living larval stage, it was really the Porto Rican $E$. auriculatus (Cope) in which this characteristic was first noticed, although all the Lesser Antillean and many of the Greater Antillean species have been at one time or another included under this name.

In Jamaica its occurrence in Hope Gardens is due to its introduction by Lady Blake (Barbour, Bull. M. C. Z., 1910, 52, p. 288). The records for San Domingo (Boulenger, loc. cit.) and Porto Rico (auct.) refer to E. auriculatus (Cope). Fielden says that it was introduced into Barbados from whence in 1882 there were specimens in the British museum. From Barbados it is said to have been introduced into Grenada; but the species from Grenada is a different species, named E. johnstonei. This may be taken to indicate that the southern Lesser Antilles support a species quite distinct from true $H$. martinicensis, and which has been introduced perhaps from St. Vincent to Barbados and Grenada. Most unfortunately no St. Vincent frogs are in the collection, and Fielden (Zoologist, 1889, p. 298) gives no clew as to whence the Barbadian frogs came. Since records from practically all the West Indies have been published for "Hylodes martinicensis," it is best to admit here only such as undoubtedly belong to this species in its restricted sense. The Museum has several hundred from Martinique, the type locality, but whence, Stejneger states, it was said to have been brought from Guadeloupe. From this island also there is a very large series in the collection. Others are preserved from St. Kitts, and neither Stejneger nor I have been able to find that they were in the least different. I can say the same for specimens from Saba, and Monserrat. It has been recorded by Cope from St. Eustatius and St. Martins. Reinhardt and Lütken (Vid. Middel. nat. foren. Kjöbenh. for 1862, 1863, p. 159) record it from Barbados; and as this is more than twenty years earlier than Fielden wrote, it does not lend any confirmation to his statement, made in 1899, that it was introduced into Barbados twenty years before that date, which would be 1869. The specimens which Reinhardt and Lütken record must have been taken prior to 1862 . There 
are other records for small frogs in the West Indies; but without specimens it is impossible to refer them to their correct position, and for that reason their records are not included in this paper.

Eleutherodactylus johnstonei, sp. nov.

Plate, figs. 1, 2, 5, 7, 9 .

Types:- No. 2,759, M. C. Z., two figured specimens, St. Georges, Grenada, G. M. Allen and C. T. Brues, collectors. Besides the types there is an enormous series of specimens, young and adults, from various localities in the coastal lowlands of the island.

Dr. Allen's notes present the following brief history of this species:- "Mr. Septimus Wells tells me that this small piping frog was introduced about 25 years ago $[i . e$ about 1885] from Barbados, and has since spread up country. It is, of course, absent from the forests of the high region about Grand Etang. I heard the last one near the side of the highway about three miles above St. George's."

I am very loath to designate as types of a new species individuals from a locality of which the species is not truly a native. Since, however, no specimens are available from Barbados, and the species was also possibly introduced there, there is no alternative but to use the material in hand.

This is a short-limbed, heavy-bodied species belonging to that section of the genus having a granular belly, and strong oblique groups of vomerine teeth posterior to the internal nares, and converging posteriorly toward the mesial line.

Tongue rather narrow, oval, free, and unnicked behind; vomerine teeth in two strong oblique series, arising immediately behind the posterior inner margin of the choanae, not extending laterally beyond the latter, and strongly converging backward, the interval between the series slightly less than their distance from the nares; nostrils much nearer tip of snout than eyes, their distance from the eyes about equal to or slightly larger than the diameter of one of the latter; upper eyelid less wide than interorbital space; tympanum almost exactly half the diameter of the eye, its distance from the eye not over two thirds its diameter; fingers with well-developed dises, first very slightly shorter than second; dises of toes smaller than those of fingers; tip of first toe not quite reaching the base of the dise of the second; two metatarsal tubercles, moderate in size, and with the outer larger than the inner; soles with rather abundant, feebly developed tubercles; no tarsal fold; the bent limbs being pressed along the side, knee 
and bowel meet; hind limb being extended along the side, heel almost reaches eye; hind limbs being placed vertically to the axis of the body, the heels just overlap, very slightly; skin above densely granular; a fairly well-defined glandular ridge along back from snout to vent; belly and hinder aspect of thighs strongly glandular; throat, upper portion of chest, and anterior aspect of thighs smooth; no differentiated adhesive disc area.

The variation in color is very great, and may be gauged by the figures of the typical specimens. Other variation is seen in the dorsal granulation, which is always well developed, however, and in the fact that in the largest individuals the heels barely meet posteriorly, when the limbs are laid vertically to the body. The extreme adults, then, have very short limbs.

The species belongs near $E$. auriculatus (Cope) from the Greater Antilles, and $E$. martinicensis (Peters) from Guadeloupe, Martinique, St. Kitts, Jamaica, and elsewhere. The latter species was, according to Stejneger (Rept. U. S. nat. mus. for 1902, 1904, p. 584), introduced from Guadeloupe to Martinique; and still more recently it has been carried to Jamaica (Barbour, Bull. M. C. Z., 1910, 52, p. 288). E. johnstonei can be separated from E. auriculatus Cope by its vomerine teeth groups, which are less extended laterally, by its larger tympanum, which is nearer the eye than in the other species, by its shorter hind limbs, and the more considerable development of tubercles on back and soles of feet. In E. martinicensis (Peters), the exposed tympanum is still less in size. E. antillensis Reinhardt and Lütken, from St. Thomas, is easily separable by its small feet. $E$. johnstonei grows to a larger size than any specimen of $E$. martinicensis which I have been able to examine. The largest Grenadian specimen is $32 \mathrm{~mm}$. from snout to vent. Porto Rican examples (E. auriculatus) reach a size of $43 \mathrm{~mm}$., according to Stejneger, and there are several of almost this size in the collection here.

In the Zoologist (1889, p. 298), Col. Fielden of Barbados makes the following note regarding what he calls Hylodes martinicensis:-

"The little Tree-frog Hylodes martinicensis, Tschudi, is undoubtedly a very recent introduction; twenty years ago, as I am credibly informed, it was quite unknown. It is now spread over the entire island...."

This is substantiated by Bellin, who wrote in 1758, in his Description geographique des Isles Antilles possedes par les Anglais (Paris, 1758, p. 61), that upon the island of Barbados "Il n'y a ni Crapauds ni Grenouilles."

This species is named for His Honor Robert S. Johnstone, Chief Justice of Grenada and the Grenadines, who very kindly aided the members of the Museum's expedition while at Grenada. 
Eleutherodactylus urichi (BOETTGER).

Plate, fig. $3,4,6,8,10$.

BOETTGER, Journ. Trinidad field, nat. club, 1894, 2, p. 88.

Without specimens from Trinidad, it is impossible to decide certainly whether the specimens which Dr. Allen brought from Grenada are absolutely the same as this species or not. They certainly agree closely with the original description, and must be very closely related, if not identical.

- The large series are from the virgin forest about the Grand Etang, a lake high up in the central part of the island. To this region this species is absolutely confined. Not a single specimen was taken in the lowlands. It occurs commonly under stones, rotten logs, and in decaying leaves and other fallen vegetation. Its note is "a series of eight or nine rapid 'criks,' the last two or three less rapid, and the whole not louder than a cricket."

The two figures show how varying the color pattern may be; and the coloring itself of the alcoholic individuals is also very various. In general it agrees with Boettger's description, but no two specimens are alike. About one hundred were preserved.

Leptodactylus pentadactylus (LAURENTI).

Ladrenti, Syn. Rept., 1768, p. 32. Bodlenger, Cat. Batr. Sal. Brit. mus., 1882, p. 241.

This species, with an enormous distribution over the South American mainland, has been recorded from but three West Indian islands,-Dominica, St. Kitts, and St. Lucia. This distribution strongly suggests an artificial introduction as an article of food. It may, however, have been extirpated upon other islands where it once occurred for this very reason.

As argument against their artificial introduction, we may cite Father Labat, who, in his accurate and engrossing narrative entitled "Nouveau voyage aux iles d'Amerique," \&c., (La Haye, 6 vols., 12mo, 1724, and Paris, 8 vols., 12mo, 1742), informs us that "On trouve a la Martinique \& en quelques-autres Isles, less plus belles Grenoüilles du monde, on les apelle Crapauds parce qu'elles sont vêtues comme les crapauds d'Europe, c'est-a-dire de gris avec des taches ou rayes Jaunes \& noires; elles ne se 'tiennent pas dans l'eau, mais dans les bois où elles croassent tres-fort, sur tout la nuit.... leur chair est blanche, tendre \& délicate on ne jette que la tête."

Upon Martinique they have perhaps been now exterminated on account of their culinary value. 
Leptodactylus inoptatus, sp. nov.

Type:-No. 3,087, M. C. Z., one male, Diquini, Haiti, W. M. Mann, collector.

Vomerine teeth in two curved series behind the choanae; tongue large, slightly indented behind; nostrils very near tip of snout; tympanum circular, over two thirds the diameter of the eye; interorbital space over twice width of upper eyelid; first and second fingers equal in length; toes but very slightly webbed at base, third and fifth of equal length; subarticular tubercles very greatly developed, soles almost smooth; two metatarsal tubercles, the inner near the origin of a vestigial dermal fold; tarsometatarsal joint reaching nostril when the hind limb is carried forward along the body; skin smooth on middorsal area, slightly granular on sides, coarsely granular on belly; two dorsolateral glandular folds; a pronounced fold from eye over tympanum to shoulder; ventral disc feebly marked; figures and toes with slightly expanded tips; fingers and toes with well-developed dermal emarginal fingers; a spine-like tubercle very prominent on posterior region of each eyelid.

Color, middorsal area lilac or purplish brown; sides heavily marbled with dusky olive; lower surfaces dirty white. A white spot near the shoulders on each side. No white stripe on lips.

In speaking of L. albilabris from Porto Rico, Stejneger says (Rept. U. S. nat. mus. for 1902, 1904, p. 561):-

"The status of the frog, Leptodactylus albilabris, is quite different from that of the other species of the fauna. In the Antilles it is restricted to the Virgin Islands, St. Croix, Vieques and Porto Rico. There is apparently no indigenous species of the genus in the Caribbean chain, the other two which occur in various islands being evidently introduced by man and belonging to widely different South American species. No Leptodactylus or related form is found in Haiti, Cuba, or Jamaica. But the most curious feature is that a frog which neither Dr. Boulenger nor I can distinguish from $L$. albilabris, is a native of southern Mexico, State of Vera Cruz, and the Isthmus of Tehuantepec. I know of absolutely no parallel to this extraordinary range, which is inexplicable on ordinary distributional grounds, for certainly it would transgress the boundaries of the probable to suppose either that this species had once covered the whole country between Tehuantepec and the Virgin Islands and become extinct in the intermediate territory, or that there had at any time been a direct connection between the localities mentioned to the exclusion of the large Antilles. Nor can it for a moment be supposed that the species exists in the latter without having attracted attention. No doubt there are many species yet to be discovered in these islands, but L. albilabris is not likely to be one of them, for it is one of the commonest, most obtrusive, and most easily caught batrachians wherever it occurs. In suggesting accidental introduction by man I am fully aware that this explanation does not at first appear plausible, as there does not seem to be or to have been any direct route of communication between southern Mexico or Yucatan and 
Porto Rico or the Virgin Islands, but I offer it as the only possibility I can think of. The wrecking of a vessel with a cargo of logwood or mahogany a hundred years or more ago might account for this remarkable distribution."

Now considering that $L$. albilabris occurs upon more than one island, it is necessary to postulate a series of unlikely events to explain its accidental occurrence. It is more probable that the Porto Rican and mainland individuals have by some fortuitous parallelism become indistinguishable if they originally belonged to different stocks or if both were derived from the same stock then they have preserved their identity in parts of their range and varied with isolation in other parts. The occurrence in the East Indies of Rana macrodon in the greater Sunda Islands and New Guinea, and of Rana modesta, a derivative of $R$. macrodon in Celebes is a case of similar distribution. The Lesser Antillean species are almost certainly not introduced, since Labat informs us that frogs ( $L$. pentadactylus) were a common article of food in Martinique and other islands as early as 1724. That they probably belonged to this species is shown by his stating that they lived in the woods and not in the water and by his description of their colors. The occurrence of a peculiar Leptodactylus upon Haiti, and there is evidence that a species occurs upon Cuba also, is not as astonishing as appears at first.

It is quite possible that other species remain undiscovered, while in the Lesser Antilles at least it is entirely probable that they may have been exterminated upon some islands because of their edible qualities. That the genus was once generally distributed throughout the area I have no doubt whatever.

In February, 1912, while collecting with Mr. R. M. Grey upon his Colonia of the Soledad estate near Cienfuegos, Cuba, we both saw a large frog leap a number of times over a grass plat and take refuge in a small pond. Mr. Grey said it was a "bull frog" and that thereabouts such frogs were rare and shy. He has been trying, so far without success, to secure one, and I also searched for it in vain. I recognized at once that it was far larger than any Eleutherodactylus which I had ever seen and at the time concluded that it was a large Hyla which was perhaps approaching the water for breeding purposes. In the light of the finding of this species upon Haiti, I have but little doubt that it was an unknown Leptodactylus.

Leptodactylus validus Garman.

Garman, Bull. Essex inst., 1887, 19, p. 14.

This species was described from St. Vincent (Types M. C. Z., No. 2,183). Later, however, Boulenger called specimens from the same island L. caliginosus 
Girard. The latter species was described (Proc. Acad. nat. sci. Phila., 1853, p. 422) from specimens taken at Rio de Janeiro by the members of the U. S. exploring expedition. Boulenger (Cat. Batr. Sal. Brit. mus., 1882, p. 247) makes $L$. caliginosus, embrace Hallowell's species, malanonotus, from Nicaragua, which is certainly a valid form, as specimens in the Museum from Nicaragua show. They differ markedly from the figure and description of Brochi's L. echinatus (Miss. sci. Mex. Batr., 1882, p. 18, pl. 5, fig. 4), and also from a specimen from Merida, Venezuela, obtained through Rosenberg of London. This frog was from material collected by Sr. Briceño y Gabaldon, which was studied by Boulenger; so that it represents exactly Boulenger's L. caliginosus. Upon comparing this specimen with a large series from St. Vincent and Grenada, I find that they are the same in every respect. The only obstacle which now remains in the way of reducing $L$. validus to a synonym is the fact that we have no topotypes of $L$. caliginosus for comparison. I did not find this species when collecting about Rio, but only $L$. poecilochilus Cope. A species of amphibian covering a range which extended from Rio de Janeiro to St. Vincent in the West Indies and to the Isthmus of Tehuantepec would be foreign to everything which we know of amphibian distributions. For this reason I keep the species separate, believing that a comparison with examples from Brazil will show this to be justified. $L$. caliginosus Girard will thus be the name for Brazilian examples, L. validus Garman for those from St. Vincent, Grenada, probably Trinidad, and certainly part of Venezuela; and L. melanonotus (Hallowell) for those from Central America, probably from Tehuantepec to Panama. I showed (Barbour, Bull. M. C. Z., 1906, 46, p. 228) that some very large specimens from San Miguel and Saboga Islands, in the Bay of Panama, were a distinct species, and gave them the name $L$. insularum.

From Dr. Allen's field notes I glean that there is no evidence that L. validus has been introduced in Grenada, and the fact that it is a species characteristic of the fauna of the small area of primeval forest still remaining in the interior of the island would make it appear certainly to be indigenous. Dr. Allen says that what he took to be this frog pipes like our common Hyla pickeringii. Specimens seen near the shore of the Grand Etang when disturbed, dove into the water, and hid among the dead leaves on the bottom. They occurred, however, in the sodden woods as well. 


\section{Leptodactylus albilabris (GÜNTHER).}

GüNTHER, Ann. mag. nat. hist., 1859, ser. 3, 4, p. 217. STEJNEGER, Rept. U. S. nat. mus. for 1902, 1904, p. 561, fig. 6-10.

The history and status of this species, which has been considered one fortuitously introduced is discussed among the remarks upon L. inoptatus, sp. nov. from Haiti.

Phyllobates limbatus Cope.

Cope, Proc. Acad. nat. gci. Phila., 1862, p. 154. Boulenger, Cat. Batr. Sal. Brit. mus., 1882, p. 195.

The types of this species were six specimens now in a very bad state of preservation which were sent to the U. S. national museum from the region of Guantanamo, Cuba, by Mr. Charles Wright, a very accomplished botanical and zoölogical collector. I can not learn that the species has been taken since until 1912. Gundlach in all his trips over the island never collected it. I found it at two neighbouring stations. One a seborucal near Colonia Limones, another in an area of dense woods near Colonia Guabairo, both on the Soledad plantation near Cienfuegos.

The seborucal, as any densely wooded area upon a region of limestone rocks is called, was like an island in a sea of cane fields and the jungle was so dense and thorny that it could only be entered by following up the bed of a small stream. In company with Mr. R. M. Grey I found one of these tiny frogs under a stone on the bank of the stream. Another was seen but not secured. Greatly disappointed, for I realized at once the identity and interest of the find, we revisited the locality several times but were unsuccessful.

Some days later while enjoying the hospitality of Captain Beal of Guabairo, Mrs. Barbour and I were collecting along an old wood trail in the early morning when we came to a stony place in the road, evidently a sort of stream bed flowed

over only during a heavy rain. By diligent searching under these stones we obtained a good series all of exactly the same minute size. The species is an extremely active and delicate one and to obtain uninjured specimens means quick and accurate work with the forceps.

The colors in life are as Cope has described them and he was certainly correct in adding that "This is perhaps the smallest frog known, and is a very prettily marked one."

Believing it probable that this species might in reality not be a true Phyllobates at all I cleared an entire specimen with chemical reagents and was thus able to study the sternum critically. The examination showed that the species was in every way a typical Phyllobates. 
The finding of one member of this genus in Cuba is the only reason for still retaining Phyllobates bicolor in the list, which is $I$ think unjustifiable.

Since the foregoing was written Mr. C. T. Ramsden has found a few specimens of this species at Monte Libano, near Guantanamo. These are approximate topotypes and thanks to Mr. Ramsden's generosity I have been able to make direct comparison of the specimens from these widely separated localities. They are exactly similar in every respect.

\section{REPTILIA.}

Gymnodactylus fasciatus Duméril et Bibron.

Duméril et Bibron, Erpét. gén., 1836, 3, p. 420. Botlmnger, Cat. lizards Brit. mus., 1885, 1, p. 31.

This the only Antillean species of the genus occurs upon Martinique. It has only been taken a few times, and of its habits, or of its possibly wider distribution, nothing is known.

Gonatodes albogularis Dumḱril et BrBron.

Duméril et Bibron, Erpét. gén., 1836, 3, p. 415. Barbour, Bull. M. C. Z., 1910, 52, p. 289.

This species, formerly supposed to be confined to Cuba, has been found in Jamaica, where it has undoubtedly been introduced by the direct carrying trade from Santiago de Cuba and Kingston. In Jamaica it has only been captured in and about the latter city. In Cuba it is common only in the region about the cities of Havana and Santiago de Cuba. I found it in houses in the latter city in 1909, and a fine adult was given me by Sr. Victor J. Rodrignez, caught in the buildings of the National University at Havana in February, 1912. Gundlach found it also in these two localities only. This distribution looks at once like a case of fortuitous introduction. It has, however, been found in the country as well, and there is a specimen in the British museum from the San. Juan River district (Boulenger, Cat. lizards Brit. mus., 1885, 1, p. 59). The principal Rio San Juan is near Matanzas and this year I saw what I am convinced was this species near Matanzas. A fine adult pair caught by Mr. Charles T. Ramsden near Guantanamo is in the Museum the gift of Mr. Ramsden.

$$
\text { Gonatodes notatus (REINHARDT \& LÜTKEN). }
$$

ReinhardT \& Lutken, Vid. meddel. nat. foren. Kjöbenb. for 1862, 1863, p. 280.

Although Boulenger (Cat. lizards Brit. mus., 1885, 1, p. 59) places this species in the synonymy of $G$. albogularis, with a query attached, it seems wisest 
to keep them separate until specimens from Haiti can be compared with others from Cuba. The description seems to indicate a valid species. The type locality is Acquin, Haiti.

\section{Phyllodactylus spatulatus CopE.}

Cope, Proc. Acad. nat. sci. Phila., 1862, p. 176. Boolenger, Cat. lizards Brit. mus., 1885, 1, p. 81.

This is apparently an excessively rare species, the types of which were caught at Barbados by Theodore Gill, who spent some time collecting upon that island. This case is more or less similar to that of Tarentala cubana, a species which is probably common enough, and yet which, on account of its crepuscular or nocturnal habits, very seldom finds its way into the hands of the general collector, and still remains very rare in museum collections.

Recently a specimen has come to hand which was collected in Curaçao. It has been compared with the types of this species by both Dr. Stejneger and myself, and there can be no doubt as to its identity.

\section{Thecadactylus rapicaudus (HoUTTUYN)}

Houtturn, Verh. Zeeuwsch. genoot. wet. Vlissingen, 1782, 9, p. 323, pl. 3, fig. 1. Boulenger, Cat. lizards Brit. mus., 1885, 1, p. 111.

This is another species of gekko which occurs in both Central and South America, and upon many of the West Indies, - in some cases possibly distributed fortuitously. There are specimens in the Museum from Saba, St. Bartholomew, St. Lucia, Dominica, Anguilla, Guadeloupe, and Grenada. Other records are St. Thomas, St. Croix, Nevis, and Antigua.

The only other species in the genus is $T$. australis Günther, which occurs on the islands in Torres Straits. Such a distribution as this can only be explained by assuming that the genus is one of extraordinary antiquity,- an assumption that we can not prove,-- or that the species are in reality unrelated, and that the similar characters are the result of the operation of some law of convergence. The species may really represent separate genera, which are possibly very distantly related to each other.

Three examples were secured by Dr. Allen in Grenada. The species is rare locally, although common on many other of the Antilles. "Wood slave," is native name according to Dr. Allen. In Jamaica this name is sometimes used for the Mabuya, and very often for Sphaerodactylus gilvitorques. For the latter genus in general, the name is "water-lizard," or "pawley lizard." Curiously enough it is never used for Aristelliger, which should suggest Thecadactylus so 
strongly to the native observer. The remarkable distribution of these widespread native names, and their curious application to different local species, would provide a most absorbing problem for some student of folk-lore and linguistics. The same sort of a series of stock-names for littoral fishes appears spread from Bermuda and Florida to the Lesser Antilles, and might well be included in the same study.

\section{Aristelliger praesignis (HALLOWELL).}

Hallowell, Proe. Acad. nat. sci. Phila., 1856, p. 222. Boulenger, Cat. lizards Brit. mus., $1885,1$. p. 146. Barbour, Bull. M. C. Z., 1910, 52, p. 289.

The Museum's specimens are from Jamaica, Grand Cayman, and Cayman Brac. This species needs comparison with $A$. irregularis Cope (Proc. Amer. philos. soc., 1885, 22, p. 387) from Cozumel Island, Yucatan, which we have not seen. The question as to whether the various mainland records for Belise and Nicaragua really refer to $A$. praesignis is one of prime importance. Do they represent the mainland inhabiting ancestors from which the Antillean individuals have been derived, or are they waifs which have been carried to the mainland from Jamaica by the considerable schooner traffic? If the former possibility is true, then we might expect $A$. irregularis Cope to stand valid. It is probably better to assume that it does (Cat. lizards Brit. mus., 1887, 3, p. 485). If not, Boulenger's contention that it is identical is doubtless correct.

\section{Aristelliger lar Cope.}

Copt, Proe. Acad. nat. sei. Phila., 1861, p. 497. Bodlenger, Cat. lizards Brit. mus., 1885, 1, p. 147.

The type of this species (M. C. Z., No. 3,607) is a very large individual, over a foot in total length. It was captured by Weinland near Jeremie, Haiti, and is the only one that the Museum has ever received.

\section{Aristelliger nelsoni, sp. nov.}

Type:- No. 7,891, M. C. Z., an adult from Swan Islands, Caribbean Sea, March, 1912, George Nelson, collector. Seven paratypes.

This species may be distinguished from its close relative $A$. praesignis by its larger average size, several specimens are $235 \mathrm{~mm}$. in length and by its shorter snout which is but slightly longer than the distance from eye to ear. Besides these characters which are not very striking, there is a marked difference in the dorsal scales. In the Jamaican examples these are rough, shagreen-like granules, while in those from Swan Island the skin is much more finely granular and much 
smoother. The type has but seven upper and five lower labials to below the posterior border of the orbit. In the series of paratypes eight upper and six lower labials are found but this is evidently not the typical condition. The ventral scales of the preanal region are larger than those of elsewhere, which does not seem to be the case in $A$. praesignis. Lamellae under fourth toe 15 in number in the type, which seems to be a constant character.

The large size, shorter and less depressed snout, the lesser number of labials, finer dorsal granular seales and rather greater number of subdigital lamellae serve to distinguish this from $A$. praesignis Hallowell. The smaller number of subdigital lamellae and smaller size separate it at once from $A$. lar Cope. Its very prominent palpebral spine separate it from $A$. georgeensis (Bocourt) from St. George Island, and its small number of labials again serve to distinguish it from A. irregularis Cope from Cozumel Island. These four are the only species previously described. The genus is recorded from Belize by Boulenger (Cat. lizards Brit. mus., 1885, 1, p. 147).

The following field notes are important. Mr. Nelson states that the species is extremely common on both Swan Islands. It is frequently heard croaking at dusk both among the cocoanut palms, in the houses (on Swan Island), and in the woods. On Little Swan Island the species occurs only in the jungle since this island is and always has been uninhabited and is without any cleared land. The island (one and one half miles by one half mile in size) rises in sheer cliffs from the ocean on all sides. There is no introduced vegetation and it is here that the peculiar mammal Capromys thoracatus True is found abundantly. There is thus no reason whatever to suppose that this lizard has come to the island fortuitously. It is ninety-eight miles from the nearest point of the Honduran coast and one hundred and thirty-five miles from the Cayman group.

This species is named for Mr. George Nelson of the Museum staff, the first to explore thoroughly these interesting islands.

Tarentola cubana GundLACH \& Peters.

Gundlach \& Petres, Monatsb. Akad. wiss. Be̊rlin, 1864, p. 384. Boulenger, Cat. lizards Brit. mus., 1,1885, p. $195 ; 3,1887$, p. 490.

This rare gekko is confined to Cuba. There are specimens in the Museum which Major Wirt Robinson, U. S. A., sent from Santiago; and the writer once had a living specimen which came from Cienfuegos and which most unfortunately was lost. Gundlach only found two specimens during his life in Cuba, one near San Diego de los Baños, in the Sierra de Rangel, and the other at Cabo Cruz. In February, 1913, I got a fine example under a stone at this same locality. 
This is the only Antillean representative, in fact the only American representative, of a genus the other species of which inhabit southern Europe, northern and western Africa, the Cape Verde Islands, and Madeira. The fact that the Cuban species is so rare in collections would make it seem possible that the species may exist on Haiti; it is not likely to occur on Porto Rico or Jamaica, or on the Lesser Antilles. It is curious that its existence in the West Indies should be confined to Cuba, although we observe too many similarities in West Indian and West African generic ranges for the general habitat of Tarentola to seem very peculiar.

Sphaerodactylus torrei, sp. nov.

Sphaerodactylus sputator Boulenger, Cat. lizards Brit. mus., 1885, 1, p. 219 (non Sparrman).

Anderson (Bihang. K. Svensk. vet-akad. Handl., 1900, 26, afd. 4, no. 1, p. 27) has shown that the name Sphaerodactylus sputator (Sparrman) must be transferred to $S$. fantasticus Duméril \& Bibron, since he has identified the original specimens from St. Eustatius in the Stockholm museum with that species. It now becomes necessary to rename the Cuban species, which I have done in honor of the distinguished Cuban naturalist, Carlos de la Torre.

This is apparently a common species in eastern Cuba. It is supposed to occur also upon San Domingo; but no comparison from the two localities can be made here, nor did Boulenger, in 1885 have any from Haiti.

Type:- No. 6,916, M. C. Z. . An adult, Santiago de Cuba, Wirt Robinson, collector. Two paratypes.

Snout rather pointed, longer than distance from eye to ear opening; ear aperture vertical, ovoid, rather small. Rostral large, with median cleft above, nostril between rostral, first labial and one to three small nasals; five upper and five lower labials; mental large, truncate posteriorly; no regular chin shields, but many polygonal scales, which pass into the throat granules. Upper eyelid with small spine-like scale above the middle of the eye. Upper surfaces with very small minute granule-like scales, largest on the snout; scales of abdomen imbricate and larger. Tail cylindrical, with verticals of scales and a row of enlarged scutes below. Dirty brown or whitish, upper surfaces with five dark brown bands between the end of the snout and sacrum, the three anteriors often extending almost or quite across neck and chest. A varying number of complete bars on tail. Two longitudinal whitish stripes on the snout.

Upon my collecting trip in $1913 \mathrm{I}$ got two fine large specimens from Cabo Cruz and Mr. C. T. Ramsden gave me a beautifully marked individual from Guantanamo. 
Sphaerodactylus elegans REINHARDT \& LÜTKEN.

Reinhardt \& Lütken, Vid. Meddel, nat. foren Kjobenh. for 1862, 1863, p. 275. Boulenger, Cat. lizards Brit. mus., 1885, 1, p. 220.

A very small species represented by individuals from San Diego de los Baños Caibarien, Remedios, and Havana, Cuba. These little lizards look very like what might be the young of $S$. torrei, of which species we have no specimens of a similar size. The measurements given by Boulenger for the largest $S$. elegans are much smaller than those which he gives for S.torrei. The type of coloration is, however, entirely different, and adults of but little more than an inch long were not uncommon at San Diego de los Baños. This was the only locality where we ourselves met the species, although we often heard elsewhere of the "Salamanquita de la Virgen," as it is called by the people. Recently four examples from Momance, Haiti, have been received from Mr. W. M. Mann.

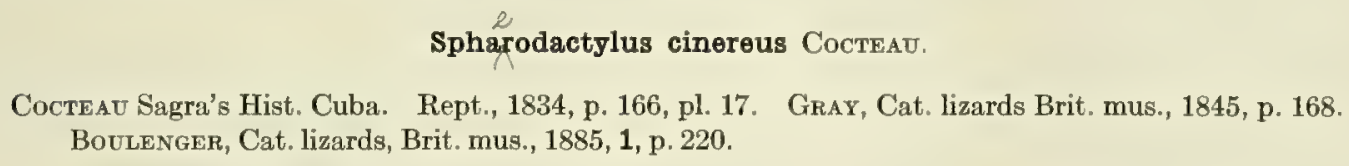

The only specimens which I have seen and which agree with this form are from Cienfuegos, Santiago de Cuba and Los Negros in Jiguani, Oriente. Boulenger records it from San Domingo, Martinique, and Caracas, Venezuela. The Martinique specimen, which was received from the Paris museum, probably came from San Domingo, as did many other specimens in the Paris museum which are labeled Martinique. The specimen from Caracas was probably either carried there by mistake, or else belongs to another species. S. cinereus is probably confined to Cuba and Haiti. Mr. Mann collected an adult at Momance, Haiti.

\section{Sphaerodactylus nigropunctatus GraY.}

Gray, Cat. lizards, Brit. mus., 1845, p. 168. Boulenger, Cat. lizards Brit. mus., 1885, 1, p. 220, pl. 18, fig. 2.

Of this species, the type locality of which was unknown, the Museum has specimens, which Garman has identified, from Santiago de Cuba, collection of Major Wirt Robinson. Recently Mr. C. T. Ramsden has sent a specimen from Guantanamo which seems to be referable to this species. It is, however, almost black in general color with two white dots side by side upon the nuchal region. 


\section{Sphaerodactylus decoratus Garman.}

Garman, Bull. Essex inst., 1888, 20, p. 111. Barbour, Bull. M. C. Z., 1904, 46, p. 57. Rosín, Lunds univ. arsskrift, 1911,7 , no. 5 , p. 27.

The type (M. C. Z., No. 6,220) is from Rum Cay. It is common upon Andros Island and rare on New Providence. Specimens from the last two localities were collected in the Bahamas during the summer of 1904 by Dr. Glover M. Allen, Owen Bryant, and myself.

This species, which in its lepidosis is so very like $S$. punctatissimus Gray and S. flavicaudus Barbour, is well marked by its strikingly conspicuous coloration, different from any other species in the section of the genus having the minute granular dorsal scales.

The thought occurs at once that $S$. punctatissimus, S. favicaudus, and $S$. decoratus may in reality be merely color phases within a species which has a lepidosis varying slightly in connection with each coloration. But this fact, and the added one that no intergrades in coloration have ever been found make it seem probable that they are really distinct species. Field observations based upon the hatching of broods of young would settle this point, as we know both young and full grown individuals of most of the forms. The coloration does not seem to change during growth. The young of $S$. decoratus looks extremely like $S$. elegans from Cuba; while the young of $S$. cinereus and $S$. flavicaudus are very alike.

Sphaerodactylus flavicaudus BARBODR.

Barbour Bull. M. C. Z., 1904, 46, p. 56. Rosén, Lunds univ. arsskrift, 1911 7, no. 5, p. 27.

The type series of fourteen specimens (M. C. Z., No. 6,953) came from Mangrove Cay, Andros Island. Rosén found it common at Mastic Point on the same island. So far as known it does not occur elsewhere.

This species is very closely related to $S$. nigropunctatus Gray, if our specimens from Santiago really represent Gray's species. The Andros examples may be distinguished by the scales of the back and flanks being more nearly the same size. The coloration is different. Major Robinson's labels state that his specimens were brown, with mustard-colored tails, while all the types of the Andros species were pale cream color in life, with brilliant yellow tails. One of Robinson's specimens shows fine dark dots thickly scattered over the dorsal surfaces. A specimen marked in this way doubtless suggested the name nigropunctatus to Gray. Boulenger mentions that the spots have faded, and the type is now brown, with tail and lower surfaces lighter. 
Sphaerodactylus alopex Cope.

Cope, Proc. Acad. nat. sci. Phila., 1861, p. 499. Boulenger, Cat. lizards Brit. mus., 1885, 2, p. 222. Garman, Bull. Essex inst., 1887, 19, p. 18.

The types, five specimens which Dr. D. F. Weinland took at Jeremie, Haiti, are the only ones in the Museum (M. C. Z., No. 3,343). They are in excellent preservation.

The species seems somewhat allied to S. oxyrrhinus Gosse, of Jamaica, but is apparently confined to Haiti and San Domingo. The specimens of S. oxyrrhinus that have been recorded from Haiti probably belong to this species.

Sphaerodactylus oxyrrhinus Gosse.

Gosse, Ann. mag. nat. hist., 1850, ser. 2, 6, p. 347. Boulenger, Cat. lizards Brit. mus., 1885, 1, p. 222.

Barbour, Bull. M. C. Z., 1910, 52, p. 291.

Known from but few specimens, all from Jamaica. Fischer (Bericht Naturh. mus. Hamburg for 1887, 1888, p. 23) records this species from Haiti; but the specimens should be re-examined. They are very likely S. alopex Cope.

Sphaerodactylus dacnicolor BARBour.

Barbour, Bull. M. C. Z., 1910, 52, p. 292, pl. 1.

The two type specimens (M. C. Z., No. 7,276) are the only ones known belonging to this species. They were from Port Antonio, Jamaica.

Sphaerodactylus argus Gosse.

Gosse, Ann. mag. nat. hist., 1850, ser. 2, 6, p. 347. BARBodr, Bull. M. C. Z., 1910, 52, p. 292.

The commonest species in Jamaica, where it occurs all over the island. What Gundlach (Erpet. Cubana, 1880, p. 59) called this species, was undoubtedly a peculiar phase of coloration of the young S. cinereus. A specimen of this species which I collected near Cienfuegos, and several from Jiguani appear as far as their general type of color pattern is concerned, to be typical $S$. argus. This, however, they certainly are not.

Sphaerodactylus argivus GARMAN.

Garman, Bull. Essex inst., 1888, 20, p. 3.

Boulenger, in the Zoological record for 1888, remarked that this was a synonym of S. argus, of Jamaica. I have examined the types - eight specimens (M. C. Z., No. 6,223) from Cayman Brac - and I find, upon comparing them with a series of over one hundred Jamaican examples, that they differ so con- 
stantly in color that they can not be considered the same as the Jamaican species, which doubtless gave rise to the Cayman Brac form. Yellow, dark-rimmed ocelli are always present in Jamaican examples, sometimes only a very few, quite scattered, and again plentiful in numbers and arranged in regular series. In many individuals these have a tendency to become confluent and to give rise to lines upon head and neck. These do not occur in S. argious, the color of which Garman has adequately described. On the mainland these individuals would be considered as representing geographic races or subspecies, and where their ranges overlapped intergrades would be expected and found. But when the individuals are confined upon islands, no intergrading on account of the geographic discontinuity of their ranges can take place. Under these conditions it is not unreasonable to consider these very similar forms "species." Werner has described S. argus continentalis from Honduras, a fact of the greatest zoögeographical interest. Its importance is emphasized by this trinomial designation; yet for the sake of consistency, we would suggest that the species be known as S. continentalis Werner (Verh. Zool. bot. gesellsch. Wien., 1896, 46, p. 345).

\section{Sphaerodactylus notatus BAIRD.}

BAird, Proc. Acad. nat. sei. Phila., 1858, p. 254. Boulenger, Cat. lizards Brit. mus., 1885, p. 226. Barbour, Bull. M. C. Z., 1904, 46, p. 57. Stejneqer, Bahama Islands, 1905, p. 331 . Rosén, Lunds univ arsskrift, 1911, 7, no. 5, p. 27.

There are specimens in the Museum from Key West, Florida, where the species was doubtless accidentally introduced; Havana, Cienfuegos, San Diego de los Baños, Jiguani, and Guantanamo, Cuba, Little Abaco, New Providence, and Stranger's Cay, Bahamas. It has also been reported from San Domingo and Great Abaco. The San Domingan specimens are undoubtedly S. difficilis Barbour.

Sphaerodactylus exsul, sp. nov.

Type:- No. 7,894, M. C. Z. an adult. Little Swan Island, Caribbean Sea, March, 1912, George Nelson, collector. A fine series of paratypes.

Closely related to $S$. notatus Baird from which it has apparently been derived. Similar to this species in all the general features of its squamation but differing markedly in having slightly smaller and very much more weakly keeled dorsal scales. Its coloration is similar in type but much brighter and more varied. A conspicuous spectacle-like marking with two white spots is often seen on the posterior neck region. I have not observed this in S. notatus.

Mr. Nelson says that these little lizards are very abundant in the accumula- 
tions of humus and fallen leaves in the cavities and depressions so very common in the sharply eroded aeolian limestone of the island.

Sphaerodactylus difficilis, sp. nov.

A new species, belonging among those having large, strongly keeled, and imbricate scales above, being without granular scales along the vertebral line, and having the breast scales smooth. Thus it is evidently related to $S$. notatus Baird and its allies. Its nearest ally is indeed S. notatus; and from this species it may be separated at once by its much greater adult size, longer tail, entirely different type of coloration, and by the somewhat larger dorsal scales, which at first sight recall those of $S$. grandisquamis and $S$. macrolepis. This similarity was so striking that two of the four specimens in hand were labeled by Garman S. macrolepis, although they had smooth breast scales, not keeled, and came from Puerto Plata, San Domingo, instead of the Virgin Islands. He identified other similar Haitian specimens as $S$. nigropunctatus.

The typical series consists of four specimens, two collected by Mr. M. A. Frazar, in December 1881, at Puetro Plata, San Domingo; the other two from Santiago de la Vega, San Domingo, caught by Mr. A. H. Verrill in 1908.

Type:-No. 7,834, M. C.Z. Santiago de la Vega, San Domingo. A. Hyatt Verrill, collector.

Snout rather rounded, not conspicuously pointed; distance of eye from tip of snout and ear opening almost equal; rostral moderate, with conspicuous median groove, nostril between rostral, first supralabial, two small postnasals and a larger supranasal, which is separated from its fellow of the other side by two small median scales; three large supralabials, followed by one much smaller (the same on both sides), a prominent supraciliary spine over the middle of the eye; head above and on sides covered with small, elongate, juxtaposed, keeled scales, those on snout enlarged; scales on back large, imbricate, keeled, about 12 to 13 , equaling in size the distance from snout to ear; mental large, nearly same size as rostral; two very large infralabials followed by a small one to below centre of eye; two small, squarish chin-shields behind mental, followed by flat smaller scales, which extend all over throat, becoming quite small, but always flat and not granular; larger and smooth on lower neck and chest, scales of abdomen larger, but seldom exceeding in size those of back; limbs with smaller, keeled, imbricate scales; similar on upper surface of tail, but smooth below, and with some widened to form rather irregular transverse plates.

Length of body snout to vent, $28 \mathrm{~mm}$. Length of tail, $31 \mathrm{~mm}$. Total length, $59 \mathrm{~mm}$. 
Color, in alcohol, light gray-brown, with many darker spots scattered irregularly over the whole dorsal area; some cover a single scale; others are composed of several dark scales juxtaposed. On the tail the spots average larger than on the body. Below, minutely speckled with dark brown upon a lighter field, throat and upper neck heavily spotted with dark brown marking but little smaller than those of the dorsal area. Under surface of tail much more heavily speckled than belly.

The two Puerto Plata specimens have darker spots merged into lines above and also lighter spots. On the shoulders of one are two enlarged white spots with a black mark between, as often seen in S. grandisquamis. In the other, no other such mark is evident; but the three dark lines run forward, one to each eye and one to the nape region. These two specimens also vary slightly from the type and from one another in the size of the dorsal scales. In one they are a little larger than in the type; in the other, slightly smaller; this is the one with the white and black shoulder mark. These two are from Puerto Plata, San Domingo (M. C. Z., No. 5,444). The fourth specimen has a narrow head, more narrow than that of any of the others. At first I thought it represented a distinct species, but artificial distortion due to capture or preservation may be responsible for the difference noted. In its other features it is the same, except that it has smaller dorsal scales, like the second specimen mentioned from Puerto Plata. It resembles this example also somewhat in coloration, - immaculate below; faint longitudinal lines on the back, three passing forward to the eyes and neck; a spectacle-like marking on the shoulders and another faint one on the sacral region (M. C. Z., No. 7,835).

More material is needed before it can be definitely settled whether all these specimens represent one species; but I think they do, and that this species is simply unusually variable in coloration and in the size of the dorsal seales. Almost, if not quite, as great variation in coloration, and that strikingly similar, too, has been described by Stejneger for S. grandisquamis of Porto Rico. This new species seems more or less to connect $S$. grandisquamis and its allies with the group to which $S$. notatus is related. It also stands between these groups in geographical position.

Mr. Mann's recent collection contains an example from Grand Riviere, Haiti which I place with this species. 
Sphaerodactylus corticolus GARMaN.

Garman, Bull. Essex inst., 1888, 20, p. 111. Strejneger, The Bahama Islands, 1905, p. 331. Rosḱn, Lunds univ. arsskrift, 1911, 7, no. 5, p. 27.

The type locality is Rum Cay (Types M. C. Z., No. 6,219). It occurs also on Watlings Island. It has not been reported from any other locality.

Though closely related to both $S$. notatus and $S$. argus with their allies, it is apparently a species easily distinguishable.

Sphaerodactylus goniorhynchus Cope.

Cope, Proe. Acad. nat. sci. Phila. for 1894, 1895, p. 440. Barbour, Bull. M. C. Z., 1910, 52, p. 291.

I can add nothing to my previous remarks on this species (loc. cit.). It is confined to Jamaica. It seems to be very distinct, and has a type of coloration which is quite unique in a genus where there is very remarkable variation along certain more or less definite lines among the different species and individuals within a species.

Sphaerodactylus gilvitorques CoPE.

Cope, Proc. Acad. nat. sci. Phila., 1861, p. 500. Boulenger, Cat. lizards Brit. mus., 1885, 1, p. 227. Barbour, Bull. M. C. Z., 1910, 52, p. 291.

The type said by Cope to be in the Museum of the Academy of natural sciences at Philadelphia is from Jamaica, to which island the species is confined.

This lizard is really not uncommon, although, on account of its burrowing habits, it is seldom seen; it has always been rare in collections of Jamaican reptiles. I found many specimens in various parts of the island, in leafy mould under logs and stones, especially while collecting Peripatus on the hills about Bath.

\section{Sphaerodactylus copii STEINDACHNER.}

Steindachner, Voy. Novara. Rept. 1869, p. 18, pl. 1, fig. 5. Boulenger, Cat. lizards, Brit. mus., 1885,1, p. 225. GüNTHer, Ann. mag. nat. hist., 1888, ser. 6, 2, p. 363.

The type specimen was said to have come from South America, with no more definite clue to its origin. It has now been found on Dominica, if Gunther's identification is correct, and this may be the true type locality; at any rate, it does not seem to have been reported definitely from anywhere else.

Sphaerodactylus microlepis REINHARDT \& LÜTKEN.

Reinhardt \& Lütigen, Vid. Meddel. nat. foren Kjobenh. for 1862, 1863, p. 278 . Boulenger, Cat. lizards Brit. mus., 1885, 1, p. 224. Boulenger, Proe. Zool. soe. London, 1891, p. 351.

Boulenger points out how this species differs from its ally, S. copii. He remarks that it is one of the most widely distributed West Indian member of the 
genus. Individuals that he considers to belong here have been collected on St. Lucia, St. Croix, and Dominica. I do not know the species from autopsy.

Sphaerodactylus pictus Garman.

Garman, Bull. Essex inst., 1887, 19, p. 20.

This species, which to judge by descriptions is well worthy of being considered separate from its Lesser Antillean neighbours, S. fantasticus, S. copii, S. vincenti, and $S$. microlepis, is represented in the collection by the types only (M. C. Z., No. 6,071), of which there are four, from the island of St. Kitts or St. Christopher.

Sphaerodactylus vincenti BotLENGER.

Boulenger, Proc. Zool. soc. London, 1891, p. 354.

No specimens of this apparently perfectly valid species have come under my observation. So far as known it is confined to St. Vincent.

Sphaerodactylus melanospilus BocovrT.

Bocotrt, Miss. sci. Mex. Reptil., 1873, p. 44.

This species, the type locality of which is St. Lucia, is not represented in the collection.

Sphaerodactylus richardsonii GraY.

Grat, Cat. lizards Brit. mus., 1845, p. 168. Boulenger, Cat. lizards Brit. mus., 1885, 1, p. 227, pl. 18, fig. 6. BarBour, Bull. M. C. Z., 1910, 52, p. 290.

This, the finest and most conspicuous member of the genus, is confined to Jamaica, where it seems to be very rare. Gosse (Naturalists' sojourn in Jamaica, 1851 , p. 254) met with only a single example, that near Montego Bay in the western part of the island; while those taken by the writer were caught near Kingston. They came from the palm-leaf thatch of old roofs. During the winter of 1911-1912 Dr. H. L. Clark of the Museum staff found it again at Montego Bay.

\section{Sphaerodactylus picturatus GaRMaN.}

Garman, Bull. Essex inst., 1887, 19, p. 19.

This species, which is very closely related to $S$. anthracinus Cope, of Mexico, is represented in the Museum by the type series, comprising three specimens (M. C. Z., No. 3,342) from western Haiti, collected by Dr. D. F. Weinland.

A comparison of these examples with Boulenger's description (Cat. lizards Brit. mus., 1885, 1, p. 225) of what he calls S. anthracinus Cope, based on a specimen from San Domingo, shows that they are beyond doubt identical. Turning, however, to Cope's original description (Proc. Acad. nat. sci. Phila., 
1861, p. 500), we note that he expressly states that his $S$. anthracinus from Mexico has four upper labials and five lower, "two large and three small.". The Haitian examples, both ours and Boulenger's, have four above and below. This character also seems to be one which is very stable in this genus.

The color described by Boulenger agrees quite well with that of our types in its important features of head lines, and spots on back limbs and tail. But Cope says, "Color black, the large dorsal scales tinged with blue." This coloration which is unique among Sphaerodactyli is coupled with the different number of labials mentioned in Cope's very inadequate description, and the fact that the type came from Mexico, while S. picturatus comes from Hriti, a province not closely related zoögeographically with Mexico, should afford sufficient reason for keeping the two species distinct, and for concluding that S. anthracinus is confined to Mexico.

Since the above was written, I have found a single specimen, also from Haiti, which Garman has identified with his species, and which I believe also is absolutely typical in squamation. It is uniform steely gray in color, and shows that Haitian specimens have a distinct dichromatism. Cope's S. anthracinus may really have come from Haiti, and it may have been inaccurately described by him. If, then, the species is not to be found in Mexico, and is really the same in the matter of the labials, Cope's name has precedence, and this species must be known as $S$. anthracinus.

This species is, moreover, very closely related to $S$. grandisquamis Stejneger, from Porto Rico. It may be distinguished by the more elongate and flatter snout, and by the slightly larger dorsal scales.

Recently a Sphaerodactylus, which, as far as one may decide from a single specimen, belongs to this species, has been received in exchange from the American museum of natural history in New York. It was collected in the Sierra de Jalibonico in Cuba. Similar individuals were called by Gundlach (Erpet. Cubana, 1880, p. 61) S. fantasticus. I have seen specimens identified by him in the "Museo Gundlach" of the Instituto de Segunda Ensañanza, in Havana. While still more recently several enormous examples have been collected by Mr. W. M. Mann at Diquini, Haiti.

Sphäerodactylus asper GARMAN.

Garman, Bull. Essex inst., 1888, 20, p. 113. Rosên, Lunds univ. arsskrift, 1911, 7, no. 5, p. 27.

The types, two specimens from Middle Bight, Andros Island, Bahamas (M. C. Z., No. 6,222) are the only specimens in the collection. Neither Rosén, 
nor Bryant, who collected in 1904 in northern Andros and about Mangrove Cay, found this species. It is large and conspicuous among Sphaerodactyli.

Garman suggests that this species may be related to his $S$. picturatus. It is indeed very closely related, differing only in having five labials above and below, and in not having the median head scales enlarged as they are in S. picturatus.

Sphaerodactylus grandisquamis STEJNEGER.

StejNeger, Rept. U. S. nat. mus. for 1902, 1904, p. 602, fig. 51-52.

This species, which had hitherto been confounded with $S$. macrolepis Günther, the type locality of which was St. Thomas, has been shown by Stejneger to be perfectly distinct, yet to have close affinity with Günther's species. Stejneger's species may easily be separated by its much larger dorsal scales. In its distribution it is confined to Porto Rico and Vieques.

Sphaerodactylus monensis MEerWarth.

Meerwarth, Mitth. Naturh. mus. Hamburg, 1901, 18, p. 20. Stejneger, Rept. U. S. nat. mus. for 1902,1904, p. 607.

A species related to $S$. macrolepis Günther and S. grandisquamis Stejneger, and confined to Mona Island.

Sphaerodactylus macrolepis ReINHARDT \& LứtKEN.

REINHARDT \& LÜTKEN, Vid. meddel. nat. foren Kjobenh. for 1862, 1863, p. 174, 279.

Originally described from St. Croix, St. Thomas, and Vieques, it was afterward confused with S. grandisquamis Stejneger. It is, so far as known, confined to St. Croix and St. Thomas, since Stejneger found that Vieques individuals belong with his Porto Rican species. The Museum has it from St. Thomas only.

Sphaerodactylus sputator (SPARRMAN).

SparRman, K. vet. akad. Handl., 1784, 5, p. 164, pl. 4, fig. 1.

Sphaerodactylus fantasticus DuMEril et Bibron, Erpét. gén., 1836, 3, p. 406, pl. 32, fig. 2. Bodlenger. Cat. lizards Brit. mus,, 1885, 1, p. 223.

As I said when describing $S$. torrei, the name S. sputator (Sparrman) must be applied to a Lesser Antillean species. Boulenger's only Antillean specimen that could belong with this species came from the island of Antigua. Its occurrence which he reports in Mexico and Venezuela would be completely out of accord with everything known regarding the distribution of the many species of this genus. Yet Reinhardt and Lütken (Vid. Middel. nat. foren. Kjobenh. for 1862, 1863, p. 277) record it from Haiti as well as from Venezuela. Individuals of Sphaerodactylus, like other gekkoids, may be carried about accidentally. The type locality was St. Eustatius for S. sputator and Martinique for S. fantasticus, 
and very probably the species are each confined to a single island. Boulenger's example from Antigua needs comparison with a topotype before its identification can really be considered settled.

Chamaeleolis chamaeoleontides (DuMéril et BIBRON).

Duméril et Bibron, Erpét. gén., 1837, 4, p. 168. Boulenger, Cat. lizards Brit. mus., 1885, 2, p. 7.

This species, which in many respects is the most remarkable development within the fauna of the whole West Indian area, is found only upon Cuba. It is far from common; and attempts to secure it usually bring in specimens of Anolis equestris, a species which is not dissimilar in general form. Dr. de la Torre told me that the only specimens he had ever seen were those collected by Gundlach. The latter unfortunately gives little information as to its occurrence, saying only, "Esta especie es rara y la he encontrado solamente en bosques." This was one of the species which we were most anxious to secure, and this year after many ineffectual searches we secured four specimens, three from the forests of the Sierra Maestra in the Jurisdietion of Jiguani and one from La Maya also in Oriente which was kindly given me by Mr. C. T. Ramsden. The Museum has also received a specimen in exchange from the U. S. national museum taken at Santiago de los Vegas by Messrs. Palmer and Riley. Still more recently a specimen from near the Rio Hanabana collected by Don Francisco Morales and received through Dr. de la Torre permit me to make careful comparison between specimens from the east and west sections of the island. They appear to be the same. Cope's $C$. porcus very probably came from Wright's collection made near Guantanamo, although it was without locality. It is apparently a synonym of this species pure and simple.

This species is frequently mentioned under the name Chamaeleolis fernandina Cocteau, in Sagra's Hist. Cuba, Rept. (French ed.) 1843, p. 145, pl. 15. Both Mr. Garman's copy and my own of Cocteau and Bibron are the French edition, and not having the Spanish edition available, I wrote to Dr. Stejneger for any notes he might furnish me from his copy. With his usual kindness he wrote as follows:- "I regret to say that the information which I have relative to the dates of Sagra's Histoire, etc. is very fragmentary, as yet .... The work appeared in two editions, Spanish and French, but the Spanish apparently slightly ahead of the French. Both were issued in parts. Parts 1 and 2 of the Spanish edition were published in 1838 and contained the text by Cocteau up to the genus Typhlops. Turtles and lizards therefore date from 1838. Then Cocteau died and Bibron wrote the snakes and the rest. The snakes appeared in 1840, of the 
French edition I know less, only that pls. 4 and 18 were published in 1838.Therefore Chamaeleolis Cocteau 1838; Anolis chamaeleoides Dum. \& Bibr. 1837; Chamaeleolis fernandina Cocteau 1838."

Xiphocencus valenciennesii (DUMÉRIL et BIBRoN).

Duméril et Bibrion, Erpét. gén., 1837, 4, p. 131. Boulenger, Cat. lizards Brit. mus., 1885, 2, p. 9. BarboUR, Bull. M. C. Z., 1910, 52, p. 293.

This conspicuous lizard is uncommon upon Jamaica, the only island where it occurs. The genus is not represented elsewhere in the West Indies. The only other species known occurs about Bogotá, in Columbia. It also is very rare in collections, so that I have not been able to assure myself as to their really belonging to one genus. Such a discontinuous distribution can only mean that the genus is a very old one, which once ranged through Central America and to Jamaica while the latter was joined to that area, and that it has died out everywhere except about Bogotá and in Jamaica; or it may be that these similar species have come to look alike by some process of convergent evolution, and that they have no actual relationship with one another. Central America may not have extended to Columbia while it was still one with Jamaica. There would seem to be no special reason why such a genus should die out in Central America; and yet among birds Sycalis jamaicae Sharpe is confined to Jamaica, and except for a closely circumscribed species peculiar to western Mexico, all the other members of the genus occur in South America from Columbia southward.

Anolis equestris MERREM.

Merrem, Syst. Amphib., 1820, p. 45. Boulenger, Cat. lizards, Brit. mus., 1885, 2, p. 21.

The largest and most conspicuous member of the genus. It occurs only in Cuba, although it has been recorded from Jamaica. Within the island, its range is general, since in the Museum there are specimens from Havana and Santiago de Cuba, as well as from other localities. The specimens which Garman recorded from Bahia (Bull. Essex inst., 1887, 19, p. 27) came, of course, from Bahia Honda, Cuba, not Bahia, Brazil. This is not made at all clear in the context, where he suggests that it may represent another species.

Upon my trip to Cuba in 1912 I made special search for this lizard, which I found far from common. I shot a half grown individual in a tree in the mountains near San Diego de los Baños, procured a fine adult, living, from a tree in the lowlands near Herradura, and saw two, only one of which was caught by the aid of Dr. J. L. Bremer, near Madruga. No other specimens were observed, 
although it is known everywhere to the people as "Camaleon verde." On my trip in 1913 I found it rarely about Guantanamo and in the Sierra Maestra, but as we were forced to be sparing of alcohol no examples were preserved.

\section{Anolis garmani SteJNeGer.}

S'tejneger, Amer. nat., 1899, 33, p. 602. Barbour, Bull. M. C. Z., 1910, 52, p. 294.

A strictly arboreal species, corresponding to the $A$. ricordii of Haiti, $A$. cuvieri of Porto Rico, and A. equestris of Cuba. It is quite widely distributed through the wooded regions of Jamaica.

\section{Anolis ricordii Domérul et BIBRoN.}

Duméril et Bibron, Erpét. gén., 1837, 4, p. 167. Boulenger, Cat. lizards Brit. mus, 1885, 2, p. 22.

This, the giant Anolis which is confined to San Domingo, was said by Duméril and Bibron to be quite common. They had but one specimen, sent to the Paris museum by Alexander Ricord, whose notes they undoubtedly quoted. As a matter of fact, the species is a rare one in collections, and is probably also uncommon in a wild state, as are its close relatives on the other Greater Antilles. Mann's Haitian collection contains two from Diquini. Other specimens in the Museum are from Santiago in San Domingo, collected by Mr. A. Hyatt Verrill.

\section{Anolis cuvieri MERREM}

Merrem, Syst. Amphib., 1820, p. 45. Stejneger, Rept. U. S. nat. mus. for 1902, 1904, p. 627, fig. 81$84,87$.

Stejneger has shown that this lizard is confined to Porto Rico, Vieques, and Tortola and that the early history as to its identity and habitat was obscure and confused.

\section{Anolis gundlachi PETERs.}

Peters, Monatsb. Akad. wiss. Berlin, 1876, p. 705. Stejneger, Rept. U. S. nat. mus. for 1902, 1904, p. 633 , fig. $89-91$.

Stejneger says that this species seems to be "confined to the coffee belt and the high mountain tops above it" in the island of Porto Rico.

Anolis monensis STEJNEGer.

StejNeger, Rept. U. S. nat. mus. for 1902, 1904, p. 646, fig. 98-101.

Related to $A$. gundlachi and A. cristatellus, and confined to Mona Island. 
Anolis cristatellus DUMÉRIL et BiBRoN.

Duméril et Bibron, Erpét. gén., 1837, 4, p. 143. Stejneger, Rept. U. S. nat. mus. for 1902, 1904, p. 638 , fig. 92-94.

Anolis scriptus Garman, Bull. Essex inst., 1887, 19, p. 23.

This Anolis is widely distributed, and extremely abundant where it occurs. There are several hundred specimens in the collection from Haiti, Porto Rico, St. Thomas, and Morant Island of the Virgin group. A comparison of this great series with the types of Garman's A. scriptus shows them to be identical. The original description of this species concluded with the sentence "Readily distinguished from A. cristatellus, which it closely resembles, by the greater size of the two vertebral rows." I can not see, however, that these are at all enlarged; and there is no other character in which they vary from true A. cristatellus. They are simply specimens of this species for which the locality label got in some way confused. They were said to have been collected by Louis Agassiz on Silver and Lena Keys, Florida. I can not learn of the location of these keys; and the lizards doubtless came from Porto Rico or St. Thomas, where the species is excessively common. I doubt the correctness of the locality label on the Haitian specimens, as I do those on the Haitian specimens of $A$. pulchellus and A. stratulus. Meerwarth, however, records specimens from the same, island (Mitth. Naturh. mus. Hamburg, 1901, 18, p. 21).

\section{Anolis stratulus CoPE.}

Cope, Proc. Acad. nat. sci. Phila., 1861, p. 209. Stejneger, Rept. U. S. nat. mus. for 1902, 1904, p. 651, fig. 105-107.

This species is a distinct and handsomely marked one from St. Thomas, Tortola, Just van Dyke, Vieques, and Porto Rico. The Museum, besides having specimens from the last mentioned island and St. Thomas, has a couple which are said to have come from Port au Prince, Haiti. Stejneger remarks that it is desirable that this locality record be verified. For my part, I think this is simply a result of a mixing of labels such as has also occurred in the case of Anotis pulchellus, which is credited to Port au Prince also, doubtless incorrectly. and in the case of $A$. cristatellus, which has been described as $A$. scriptus from the Florida Keys.

\section{Anolis homolechis (COPE).}

Cope, Proc. acad. nat. sci. Phila., 1864, p. 169. Boulenger, Cat. lizards, Brit. mus., 1885, 2, p. 28.

This widely distributed but quite uncommon woodland species may easily be distinguished from every other Anolis on Cuba by its ivory-white dewlap. 
We found it at Soledad, near Cienfuegos and in the forest about Madruga, south of Matanzas. We also have it from Matanzas itself collected in 1912 by V. J. Rodriguez and brought to the Museum by Dr. C. de la Torre. It is also not rare in the heavy forests of the foothills of the Sierra Maestra and in 1913 we found it in the woods near Pozo Prieto, back of Los Negros, Jurisdiction of Jiguani, and also at Cabo Cruz. It is confined to Cuba.

Anolis gingivinus CoPE.

Cope, Proc. Acad. nat. sci. Phila., 1864, p. 170. Boulenger, Cat. lizards Brit. mus., 1885, 2, p. 28, pl. 2, fig. 1.

Anolis virgatus Garman, Bull. Essex inst., 1887, 19, p. 41.

Boulenger, in the Zoological record for 1887, was the first to place Garman's species from St. Bartholomew in the synonymy of Cope's species from Anguilla. This I can confirm definitely, as I have compared a topotype from Anguilla (M. C. Z., No. 6,157) with the type series of thirty-five specimens which F. Lagois collected on St. Bartholomew and described by Garman (M. C. Z., No. 6,165). A comparison of the text of Cope's and Garman's descriptions, or of Boulenger's description of Cope's species, will show that they are all obviously describing the same form. It is strange that Garman should not have noticed this, since he had this same Anguilla specimen for comparison, but separated by many pages in his list from the description of $A$. virgatus. In the jar with Garman's types I find a label which identifies them with Daudin's Anolis lineatus. According to Boulenger this species has keeled ventral scales, which $A$. gingivinus has not. Another label suggests that this species may be A. alliaceus Cope, also from "Anguilla Rock near Trinidad." Cope, however, described that species from specimens having no locality, and Gunther places $A$. alliaceus as identical with specimens from Dominica.

In 1869, Cope (Proc. Amer. phil. soc., 11, p. 159) recorded this species from the island of St. Martins.

In 1871 Cope noticed it from St. Eustatius, saying also, "This species was described by me from specimens in the British Museum said to be from 'Anguilla Rock, near Trinidad.' It appears from Dr. van Rijgerma's investigations, (Proc. Acad. nat. sci. Phila., 1871, p. 220) that the island of Anguilla, far north of Trinidad, was meant."

Anolis alliaceus CoPE.

Cope, Proc. Acad. nat. sci. Phila., 1864, p. 175. GüNTher, Ann. mag. nat. hist., 1888, ser. 6, 2, p. 363.

This species was first described from specimens without any data as to locality. Günther declares that specimens from Dominica are indistinguishable 
from the type, so that Anolis oculatus Cope is a straight synonym of this species. The only unfortunate feature of Günther's notice is the fact that he claims Garman's $A$. lividus, from Montserrat, and A. sabanus, from Saba, are the same as Cope's A. alliaceus. This is not the case; and such a statement makes one doubt whether the identification of $A$. oculatus and $A$. alliaceus may not perhaps be equally faulty. The descriptions, however, encourage the belief that this settlement of the status of the Dominican lizard may be correct.

\section{Anolis asper Garman.}

Garman, Bull. Essex inst., 1887, 19, p. 31.

In regard to this and other species, the validity of which has been doubted by Boulenger in the Zoological record for 1887, I can only say that the types agree with Garman's descriptions; and a careful reading of these will in every case, I think, point out the characters by which the species may be distinguished inter se. This species was included with A. nubilus, A. sabanus, A. speciosus, and $A$. lividus, in what Boulenger called A. leachii (Zool. rec. Rept., 1887). Günther split this species in 1888, and retained $A$. lividus and $A$. sabanus in what he called $A$. alliaceus. Both of these courses are incorrect, and an examination of the large typical series of each species show that all of them may easily be distinguished. This species occurs upon Marie Galante, whence came the large series of types (M. C. Z., No. 6,162).

Anolis speciosus Garman.

Garman, Bull. Essex inst., 1887, 19, p. 42.

This species also occurs on Marie Galante, and is easily distinguishable from the other species on that island (A. asper) by the characters given in Garman's original description (M. C. Z., No. 6,172).

Anolis lividus GaRMaN.

Garman, Bull. Essex inst., 1887, 19, p. 43.

A distinct species from Montserrat, represented in the collection by almost fifty specimens, the types (M. C. Z., No. 6,176, 6,177).

Anolis sabanus Garman.

Garman, Bull. Essex inst., 1887, 19, p. 39.

This striking species, with a bold and entirely unique type of coloration, is found upon the Dutch Island of Saba, whence the types were sent to the Museum by F. Lagois (M. C. Z., No. 6,161). 
Anolis nubilus Garman.

Garman, Bull. Essex inst., 1887, 19, p. 32.

A distinct species, so far known only from the island of Redonda, where Richardson captured the types (M. C. Z., No. 6,181).

Anolis leachii Duméril et BiBron.

Duméril et Bibron, Erpét. gén., 1837, 4, p. 152. Boulenger, Càt. lizards Brit. mus., 1885, 2, p. 29 (part).

Duméril and Bibron did not know whence came the type of this species, except that it was from the Antilles. The identity of this species with Anolis ferreus Cope, from Guadeloupe, fixes its locality. Boulenger's concept of this species embraced individuals from Guadeloupe, Dominica, Nevis, and he stated that the lizards from St. Eustatius were the same. Günther recognizes the distinctness of the Dominica specimens as A. alliaceus Cope $(q . v$.); and unfortunately no material is available here from the other islands, so that the status of Nevis and St. Eustatius specimens must remain in doubt. Boulenger has also recorded the species from Antigua, but specimens from this island should also be compared with those from Guadeloupe (Ann. mag. nat. hist., 1894, ser. 6, 14, p. 375).

Anolis cepedii Merrem.
Merrem, Syst. Amphib., 1820, p. 44. Garman, Bull. Essex inst., 1887, 19, p. 34.

Garman identifies an enormous series of specimens from Martinique with this poorly characterized species. There seems, however, to be no reason why this should not be done; and the name thus takes precedence over $A$. alligator Duméril \& Bibron, which has been used by Boulenger and many others. This species seems to be confined to Martinique, and is closely related to $A$. trinitatis Reinhardt \& Lütken ( $q . v$.).

\section{Anolis griseus Garman.}

Garman, Bull. Essex inst., 1887, 19, p. 36.

Although Boulenger (Proc. Zool. soc. London, 1891, p. 355) has considered this species a synonym of Anolis richardii Duméril and Bibron, nevertheless it is safer to consider these species distinct. Boulenger had no topotypes of $A$. richardii, which are said to have come from Tortola; and until such specimens are compared directly with this species from St. Vincent, an opinion as to its validity 
carries no weight. Duméril and Bibron's descriptions, while often verbose, generally omit mention of the characters which are now known to be most diagnostic in Anoles. The types of this species from near Kingston, St. Vincent, are M. C. Z., No. 6,184.

Anolis vincentii Garman.

Garman, Bull. Eissex inst., 1887, 19, p. 46.

This lizard has by Boulenger been called a variety of "Anolis alligator" (Proc. Zool. soc. London, 1891, p. 255); and if it existed on the mainland where the ranges of the forms might overlap such an expression would fit the conditions. But insular faunae remain perfectly isolated; and as no transition zones exist about them, the groups of individuals differentiated upon each island must be considered as species, unless they are absolutely identical with those on another island. The types of this species are M. C. Z., No. 6,178-6,179, and came from St. Vincent.

\section{Anolis Iuciae Garman.}

Garman, Bull. Essex inst., 1887, 19, p. 44.

This species is perfectly distinct, and has been adequately described by Garman. There is no occasion to combine it with A. extremus Garman, or with what Boulenger has called $A$. alligator in remarking that these, with $A$. gentilis Garman and $A$. cinereus Garman, were all one species. The peculiar character of the dorsal lepidosis, noted by Garman, serves at once to separate this species from the others. It is known from the island of St. Lucia, whence Garman collected the types (M. C. Z., No. 6,173).

\section{Anolis extremus Garman.}

Garman, Bull. Essex inst., 1887, 19, p. 35.

I can not agree with Boulenger (Zool. rec. Rept. for 1887) in considering this species a synonym of what he calls Anolis alligator Duméril \& Bibron. Nor can I agree with Garman in considering it a variety of $A$. cepedii Merrem, which is the name he prefers for A. alligator. A comparison of the types (M. C. Z., No. 6,183) with Garman's original description and with the other species leads me to the conclusion that the description is perfectly accurate, and shows well how different this species is from its relatives. This form is found upon Barbados. 
Anolis marmoratus Duméril et BiBron.

Duméril et Bibron, Erpét. gén., 1837, 4, p. 139.

Having no Guadeloupe specimens, I am unable to test the question of the distinctness of this species from A. leachii. Boulenger (Cat. lizards, Brit. mus., 1885, 2, p. 31) says:- "I am not able to detect in the description a single character of sufficient importance to justify a separation of this form from A. leachii." Since that was written Günther has admitted $A$. alliaceus Cope from Dominica to be different from $A$. leachii; and it would be very strange to find the same lizard upon Guadeloupe and Martinique, and a different one upon Dominica. So that, upon this inferential evidence alone, there is but little doubt as to the validity of the species. Garman has identified a large series from the island of Desirade as belonging here; they should, however, also be compared with specimens from Martinique.

Anolis bimaculatus (Sparrman).

Sparrman, K. vet. akad. Handl., 1784, 5, p. 179, pl. 4, fig. 4. Garman, Bull. Essex inst., 1887, 19, p. 29.

With this ancient and much disputed species Garman has identified specimens from St. Kitts and Nevis. This seems an excellent solution of the question. There can be no doubt of the distinctness of lizards of these islands from those of Guadeloupe (A. leachii) and Dominica (A. alliaceus) with which this species was associated by Boulenger (Cat. lizards Brit. mus., 1885, 2, p. 29), who included it in part with what he called Anolis alligator, another composite species. In a recent letter, Dr. Stejneger calls my attention to what Andersson has to say regarding this species (Bihang. Svensk vet.-akad. Handl., 1900, 26, 4, 1, p. 27). He has the types from St. Eustatius in hand, and believes that the name should replace $A$. leachii; but the species are better kept apart until examples from Guadeloupe can be compared with others from these three islands.

Anolis richardii Duméril et Bibron.

Duméril et Bibron, Erpét. gén., 1837, 4, p. 141. Boulenger, Cat. lizards Brit. mus., 1885, 2, p. 37.

In spite of the direct statement of O'Shaughnessy (Ann. mag. nat. hist., 1875, ser. 4, 15, p. 275), that Gray's A. occipitalis and A. stenodactylus belong to this species, which Duméril and Bibron described from the island of Tortola, we can but emphasize the enormous discrepancies between the descriptions of all these species. Boulenger has followed O'Shaughnessy; but by examining the list of specimens in the British museum given by Boulenger, it may be observed that 
no topotypes were available for comparison. So that these opinions as to the status of Gray's species carry no weight whatever, since with Anoles such matters can be settled only by the comparison of well authenticated material from a definite locality. Unfortunately the case was complicated by the fact that Gray's $A$. occipitalis had no definite data regarding origin; and his type of $A$. stenodactylus was said to come from Jamaica, where the species does not occur. Until these types can be critically compared with Tortola specimens, their status must remain unsettled.

\section{Anolis trossulus Garmar.}

Garman, Bull. Essex inst., 1887, 19, p. 14.

This lizard, which Garman found abundant in Grenada in 1887 is still by far the most abundant reptile on the island; and Dr. Allen obtained a very large series, and brought back as well living examples, two of which successfully passed through a New England winter at ordinary room temperature. They feed voraciously on flies and meal worms, and make most interesting pets. The following are Allen's field notes regarding the color of the gular appendage in wild living examples:-

"Gular sac dark brown on anterior edge, and on the anterior part of the scale rows; posterior ventral edge paler brown; scale-rows on posterior half, or two-thirds of the sides of the sac, are pale greenish yellow, the skin between the rows pale tea-color."

Allen records many wild specimens as being "nearly blackish above with greenish mottlings; below chin green, angles of jaw white with black mottlings, belly green; inside of legs green." In our living specimens here in captivity, the most common condition is a uniform or slightly mottled or clouded rich brown above, on each side a lateral band of light green. The belly is light green, limbs barred or mottled with green and brown. This color may change under excitement to uniform brownish or greenish, or to a condition where dark crossbars are present on the dorsum. A short, very light green stripe near the axilla, and white lines on the lips, are frequently present. The green lateral band is seldom lost, and that only under conditions of the greatest fright or excitement. The color phases appear to be very clearly controlled by the emotions, as is common with other color-changing reptiles. While this is not the sole factor underlying metachrosis, it is certainly far more important than many experimentalists are wont to believe. I know of no field observer of living lizards who has not been impressed this same way.

The types of this species are M. C. Z., No. 6,181. 
Anolis trinitatis REINHARDT \& LÜTKEN.

REINHARDT \& LÜTKEホ, Vid. Meddel. nat foren Kjöbenh. for 1862, 1863, p. 269.

Anolis gentilis Garman, Bull. Essex inst., 1887, 49, p. 34.

Anolis cinereus Garman, loc, cit., p. 35.

The latter synonymous form was described as a subspecies, and was founded by Garman upon color differences, which he states were evident in comparison with specimens of $A$. trinitatis Reinhardt \& Lütken. The color was said to be "intermediate between that of the light-grayish varities, from Trinidad and Petit Martinique [A.gentilis] and the brownish from Barbadoes," [A. extremus]. It is described as being "olive or bluish; the legs show more of the lilac color." According to Allen's careful and extensive field notes, made from the living specimens, they are described as being invariably light grayish in life, and as being found entirely confined to the shore formation of vegetation. They are almost always found on the bark of the cocoloba and manchioneel trees; indeed, Allen found them nowhere else, and never took one in the interior of the island. Allen reports that the belly is grayish in life, the upper side often spotted, and the gular appendage pale gray, or perhaps better, greenish gray. He was requested especially to investigate this latter character, as the pouch color is a very valuable diagnostic feature. Until comparison can be made directly with the allied forms in their living state, it is impossible to separate specimens from Trinidad, Grenada, and Petit Martinique.

Boulenger (Cat. lizards Brit. mus., 1885, 2, p. 31) considers A. trinitatis a synonym of $A$. alligator so-called. A comparison of numbers of specimens from Trinidad and Martinique shows that this is not justified, and the species should stand alone as quite distinct from A. extremus from Barbados, on the one hand, and from $A$. cepedii from Martinique, on the other. On zoögeographical grounds this course is reasonable, since the fauna of Trinidad, Grenada, and the Grenadines is more homogeneous than is the fauna of Grenada and Barbados, or Grenada and St, Lucia or Martinique.

\section{Anolis grahamii Gray.}

Grat, Cat. lizards Brit. mus., 1845, p. 247. Barbour, Bull. M. C. Z., 1910, 52, p. 296.

A Jamaican lizard easily confused with the following, but perfectly distinct. It occurs only in eastern Jamaica, so far as my collecting shows. The specimens which I recorded having taken at Mandeville were really from Mooretown. 
Anolis opalinus Gosse.

Gosse, Ann. mag. nat. hist., 1850, ser. 2, 6, p. 345. 'BArbour, Bull. M. C. Z., 1910, 52, p. 296.

A rare Jamaican species now. It is confined to the western part of the island, where Gosse reported it as common; but as this region is not very densely populated, the mongoose has made greater ravages here than elsewhere among the lizards. Near villages the mongoose is often hunted and killed as a pest, and near these villages the lizards persist most abundantly.

Anolis iodurus Gosse.

Gosse, Ann. mag. nat. hist., 1850, ser. 2, 6, p. 344. Barbodr, Bull. M. C. Z., 1910, 62, p. 295.

A species which has been confused with $A$. grahamii Gray. It is quite widespread, but nowhere very common in Jamaica.

Cope (Proc. Acad. nat. sci. Phila., 1861, p. 210) says:- "the ventral plates of this species are usually smooth; they are sometimes carinate. Specimens exhibiting the latter structure have been described by Dr. Hallowell as A. punctatissimus." It is thus evident that Cope confused A. iodurus Gosse, with smooth ventrals, and $A$. grahamii Gray, with keeled ventrals, as so many herpetologists have. I have noted the distinctness of both these species and $A$. opalinus in my Notes on the herpetology of Jamaica (Bull. M. C. Z., 1910, 52, p. 295).

Anolis conspersus Garman.

Garman, Proc. Amer. philos. soc., 1887, p. 273.

Garman, in describing this species, compared it with the Jamaican $A$. grahamii. This is not apropos; the species need comparison only with $A$. iodurus, since it has perfectly smooth ventrals. Boulenger (Zoöl. rec. Rept. for 1887, p. 10) says that this species is the same as $A$. grahamii, which is doubly incorrect. The species is a distinct and easily recognizable one. The extremely sharp, knife-like canthal ridge, and the very small occipital shield, as well as other characters, distinguish this species at once from its Jamaican ally, A. iodurus. It is confined to Grand Cayman Island, whence we have a type series of eightyseven examples (M. C. Z., No. 6,021).

\section{Anolis distichus CoPE.}

Cope, Proc. Acad. nat. sci. Phila, 1861, p. 208. Botlenger, Cat. lizards Brit. mus., 1885, 2, p. 33.

This species comes from New Providence, Great Abaco, and Cat Island in the Bahamas; and, according to Boulenger, is the same as the A. dominicensis 
of Reinhardt \& Lütken. I have compared specimens from the Bahaman Islands with Cope's type (M. C. Z. No. 3,346), from Jeremie, Haiti, and find that they differ very slightly. In Bahaman specimens the canthus is not so steep and sharply angled, nor is the internasal region quite so prominent. They are, except for these trifling differences, which are only evident in the average, and which are subject to individual variation, absolutely alike. If we knew the color in life of the dewlap of Haitian specimens, we might, - I may almost say we should,- find it different from Bahaman. Rosén has separated the Andros Island individuals largely on this excellent character.

Anolis distichoides Rosén.

Roskes, Lunds univ. arsskrift, 1911, 7, no. 5, p. 29, fig. 12, a-d.

A species very closely allied to $A$. distichus Cope, and confined to Andros Island. In life it has a gular appendage, yellowish red in color instead of light yellow. There are other small and apparently variable differences in squamation.

\section{Anolis cybotes Cope.}

Cope, Proc. Acad. nat. sci. Phila., 1862, p. 177. Botlenger, Cat. lizards Brit. mus., 1885, 2, p. 34, pl. 1, fig. 5 .

This species was among the many from Haiti which the indefatigable Weinland collected at Jeremie, and of which the types are in the Museum (M. C. Z., No. 3,619). Other specimens have come to hand from Samaná, San Domingo, so that the species evidently has a wide range over the island. Mr. Mann also collected many at Diquini, Haiti.

\section{Anolis haetianus Garman.}

Garman, Bull. Essex inst., 1888, 20, p. 42.

The types of this species (M. C. Z., No. 6,191), which are three in number, certainly differ from specimens of $A$. cybotes Cope in having keeled ventral scales. The other differences of which Garman speaks are well marked. There is another important character, however, which he overlooked, and that is that the size of the plate-like scales on the frontal region are much larger in this species than in $A$. cybotes.

Known from Haiti only.

Anolis citrinellus Copt.

Cope, Proc. Acad. nat. sci. Phila., 1864, p. 170, pl. 1, fig. 3. Boulenger, Cat. lizards Brit. mus., 1885, 2, p. 35 .

A beautiful little species, confined to Haiti. The specimens in the Museum are from the vicinity of Port au Prince (M. C. Z., No. 1,326). 
Anolis poncensis STEJNEger.

STEJNEger, Rept. U. S. nat. mus. for 1902, 1904, p. 665, fig. 117-120.

A species closely circumscribed by the bounds of a small area near the city of Ponce, Porto Rico.

Anolis evermanni STEJNEGER.

Stejneger, Rept. U. S. nat. mus. for 1902, 1904, p. 647, fig. 102-104.

Confined to the same regions in Porto Rico as A. gundlachi.

Anolis krugi Peters.

Peters, Monatsb. Akad. wiss. Berlin, 1876, p. 707.

Known only from Porto Rico, closely related to $A$. poncensis and $A$. pulchểlus.

Anolis acutus HaLLoweLL.

Hallowell, Proc. Acad. nat. sei. Phila., 1856, p. 228, Boulenger, Cat. lizards Brit. mus., 1885, 2, p. 36.

A species not very distantly related to Anolis krugi of Porto Rico, but confined to St. Croix in the Virgin group.

Anolis isolepis Cope.

Cope, Proc. Aead. nat, sci. Phila., 1861, p. 214. Boulenger, Cat. lizards Brit. mus., 1885, 2, p. 46.

A very rare Cuban species. In the collection here there is an excellently preserved adult which was received from the American museum of natural history by exchange. It was collected by Mr. Barnum Brown, probably in the Sierra de Jatibonico, Cuba. More recently during February, 1913, we procured a specimen in the heavy forest which lies beyond Los Negros in the Sierra Maestra, Jurisdiction of Jiguani. Since then I have examined a specimen taken by Mr. C. T. Ramsden near Guantanamo; he kindly informs me that the color of the dewlap in life is "apricot yellow."

Anolis lucius Duméril et Bibron.

Dumḱril et Bibron, Erpét. gén., 1837, 4, p. 105. Botlenger, Cat. lizards Brit. mus., 1885, 2, p. 45 (part).

This species both Dr. Stejneger and myself believed to be distinct from the following on the basis of Cocteau's beautiful plate in Sagra's work, compared with Cope's description and specimens referred to $A$. argenteolus from the 
Province of Oriente, Cuba. Now a comparison can be made of specimens taken by us at Madruga, in the province of Matanzas, and at Matanzas itself, and others taken by Dr. de la Torre at Matanzas and still others taken in central Cuba by Messrs. F. M. Chapman and Barnum Brown of the American museum in New York. These examples show that the species A. lucius is found in central Cuba, viz., at Matanzas, Sierra de Jalibonico, Sancti Spiritus, Trinidad and Madruga, and is very distinct from $A$. argenteolus, the type of which came from Monte Verde, near Guantanamo in eastern Cuba. A notice of the distinctive character is given under the discussion of the next species.

\section{Anolis argenteolus CoPE.}

Cope, Proc. Acad. nat. sci. Phila., 1861, p. 213.

There are specimens of this species in the collection from about the city of Santiago de Cuba, collected by Major Wirt Robinson and by myself in 1908 . In 1913 we found that this species has a wide distribution in eastern Cuba, and collected it in Cabo Cruz, Los Negros in Jiguani, Bueycito near Bayamo, and from Monte Libano near Guantanamo.

It may be distinguished at once from specimens of, or from Cocteau's figure of, $A$. lucius by its coloration and form. It is a much more slender species, having a very narrow head almost twice as long (from tympanic orifice to snout) as broad, whereas $A$. lucius has a head barely once and a half times as long as broad. In the former species the head, and especially the snout, is very depressed, almost spatulate; this is not the case with $A$. lucius, in which the profile line from top of head to tip of snout is simply a gently inclined plane surface. The color of A. argenteolus is a more or less uniform ashy gray, with mottlings of slightly darker gray. The dewlap is greenish white, the throat being pure white in the male, and mottled with darker in the female. A. lucius is conspicuously banded on the back with generally five distinct dark gray bars across an ashy gray field. A broad white band is always present encircling the entire head. This is very evident in life and passes along the lips and around the back of the neck. There is a white spot invariably present on the occipital region, which is not found in $A$. argenteolus. The two species are so different in habit and coloration as to perfectly easily distinguish them from a considerable distance when they are observed in a wild state.

It is a noteworthy fact that this and the preceding species are entirely confined to cliffs of limestone rock. They are sometimes found upon trees growing on or near the "paredones" but far more often upon the rock itself. 
Both this species and A. lucius are confined to the island of Cuba, one being confined to the central region and the other replacing it in the eastern province of Oriente.

\section{Anolis wattsii Boulenger.}

Boulenger, Ann. mag. nat. hist., 1894, ser. 6, 14, p. 375 .

This distinct and interesting species is known from the island of Antigua only. Boulenger notes its very close relationship to Anolis krugi of Porto Rico.

\section{Anolis lineatopus Gray.}

Grat, Ann. mag. nat. hist., 1840, 5, p. 113. Bodlenger, Cat. lizards Brit. mus., 1885, 2, p. 39, pl. 1, figs. 1-2. BARBour, Bull. M. C. Z., 1910, 52, p. 294.

A very common species, apparently confined to the hot, rather dry coastal plain region about Kingston and Spanish Town, Jamaica.

Anolis sagrei Dumeril et Bibron.

Duméril et Bibron, Erpét. gén., 1837, 4, p. 149.

This species, which is so closely allied to the one following, is very common in Cuba, where I have taken it about Havana, Pinar del Rio, Puerto Principe, Matanzas, Guantanamo, Santiago, and in fact at every locality where I have ever collected on the island; and there are specimens in the Museum from other places, showing it to be ubiquitous. It occurs upon Jamaica, whence Stejneger has received specimens, some of which are now in the M. C. Z. I was unable to find it there. Boulenger (Cat. lizards Brit. mus., 1885, 2, p. 40) records it also from Belise and the surrounding region, as well as Caracas. I have seen no individuals from the mainland, but feel very skeptical as to whether any species of Anolis has such an improbably discontinuous range.

Anolis ordinatus CoPE.

Cope, Proc. Acad. nat. sci. Phila., 1864, p. 175.

I follow Dr. Stejneger in considering the Bahaman lizards so closely allied to $A$. sagrei as really being distinct, in spite of the more recent assurance of Rosén that they are not. The difference in dewlap color of which Stejneger speaks is a character which I also have learned in the field to be of very great taxonomic importance. The lizard is recorded from most of the northern Bahamas. M. C. Z., No. 3,424 is said to come from Double Headed Shot Key, Florida. This record is in need of confirmation. 
Anolis nelsoni, sp. nov.

Type:- No. 7,892, M. C. Z. an adult male from Swan Islands, Caribbean Sea, March, 1912, George Nelson, collector. A large series of paratypes.

This species belongs with those having in the male a tail strongly compressed especially along its upper edge; ventral scales keeled; supraorbital semicircles separated by one row of scales. Thus its nearest relatives are $A$. sagrei Dum. \& Bibr. and A. lineatopus Gray. It is more similar to the former than to the latter species.

It is so conspicuously different from both species that it is only necessary to point out the distinguishing characters. It differs from A. lineatopus Gray in having a slightly more pointed snout; in having all the scales of the head and snout much larger. The frontal ridges enclose but two or three instead of three, four or even five series of small scales. The ridges themselves consist of but three much elongated scales instead of five - six much less prominent scales. The scales of the whole snout region are much larger and more strongly keeled than in the Jamaican species. The dorsal scales are similar in size and character. The ventrals of $A$. nelsoni are keeled and have the keels forming continuous ridges as in $A$. sagrei. The nuchal and dorsal fold as well as the crest of the tail is much more strongly developed in the Swan Island species than in either of its relatives. From A. sagrei it may be distinguished at once by its dewlap color, deep olive-gray instead of flaming orange almost pink. The ventrals are also smaller and less strongly keeled. The head scales are similar in arrangement but larger and much more strongly keeled. The dorsal scales are not feebly keeled and while very small are nevertheless imbricate and strongly keeled. There can be no question as to the close relationship of these two species yet the Swan Island form is strongly differentiated.

Mr. Nelson's field notes show that this lizard is excessively abundant in all situations on both islands. He remarks that they ehange color very freely. A few young examples especially preserved to show their brilliant marking are noteworthy in having a brilliant lemon-yellow head, besides the usual gray rhombs in a blackish area, as is seen in $A$. sagrei.

Anolis greyi, sp. nov.

Type:- No. 7,890, M. C. Z. an adult male, Camaguey (Puerto Principe), central Cuba. March, 1909, Thomas Barbour, collector. Three cotypes. Other specimens from the original series in the U. S. national museum.

When I identified the collection made in Cuba in 1909, I mistook this species 
for Anolis homolechis, a species having a pure white dewlap in life and smooth ventrals. On our recent visit to the island we found the true $A$. homolechis near Cienfuegos and Madruga. A comparison at once showed that the series of specimens from Camaguey really represented an undescribed form more closely related to Anolis sagrei than to any other species. Its relationship is so evidently with this well-known and widespread form that it is less confusing to point out the differences between these two species than to present a prolix diagnosis.

Comparing adult males, the frontal ridges of $A$. grayi are much more nearly parallel than in $A$. sagrei. In the former species they are separated usually by but a single row of scales or perhaps by two small scales lying side by side. In the latter, however, there are either two or three distinct rows filling in the ovoid area limited by the ridges. This is the most striking difference. In $A$. grayi the head is more depressed, giving a very much more flat profile, not so declivous as in $A$. sagrei. In this species also the ventrals are heavily keeled, while in the new one the keels, while distinct, are far less strongly developed. A less conspicuous distinction is the possession of larger and flatter plates about the occipital scale than are found in $A$. sagrei.

The color is similar - the same in alcohol. I remember very distinctly that when these specimens were collected, there was a prominent difference in the dewlap color in life. Most unfortunately I did not realize at that time how valuable a diagnostic feature this color character is.

I have named this species for my friend, Mr. Robert M. Grey, who is in charge of the Harvard Botanical Station maintained at the Soledad estate near Cienfuegos by the generosity of Mr. Edwin F. Atkins of Boston.

Anolis bremeri, sp. nov.

Type:-No. 7,889, M. C. Z. a single adult male, Herredura, Cuba, February, 1912, Thomas Barbour, collector.

This species belongs near A. sagrei, and its allies having keeled ventral scales, but differs in squamation and in having a very large dewlap which is rich deep maroon-brown in life, while in $A$. sagrei it is smaller and orange-red, flecked with gray.

Adult male. Top of head with two curved frontal ridges which converge anteriorly and inclose a shallow frontal area. Head scales including those of the supraocular disc all strongly keeled. Supraocular semicircles separated by a single row of scales, three of which are elongate and elevated to form a short 
but distinct median ridge. Occipital about half the size of the ear opening and separated from the supraocular semicircle by two or three rows of scales. Supraocular disc composed of eight polygonal keeled scales, separated from the semicircle by a single row of very small granular, polygonal or elongate scales. Canthus rostralis composed of few scales, one extremely elongated in the middle and flanked by others less elongate on either side. Superciliary ridge consisting of one very long anterior shield, followed by a number of much smaller scales. Loreal rows five; subocular semicircle strongly keeled; supralabials six, suture between fourth and fifth being about under the centre of the eye. Temporal seales small and granular, bordered above by a rather irregular zone of enlarged scales, which extends from the posterior border of the orbit to a point some distance above the ear opening. Dorsals small, flat, smooth, showing no tendency to imbricate, a median zone consisting of from three to four series of enlarged more or less distinctly keeled scales. This zone commences at about the region of the fore limbs. Ventrals much larger than dorsals, imbricate and distinctly but not strongly keeled. Fore limbs above with rows of very strongly keeled and enlarged scales, similar scales being also present on the anterior aspect of the thigh. Subdigital expansions feebly developed, consisting of about eighteen transverse lamellae under phalanges II and III of fourth toe. Tail strongly compressed with about fifteen evident verticils along its proximal region. Each of these is separated by about seven vertical rows of keeled scales. Upper edge feebly serrated, each section with four small spines. Dewlap very large and capable of great dilation, extending along the midventral line to a point considerably posterior to the line of the axillae. A very few feebly enlarged postanal scales. No dorsal fold.

Color of living animal, grayish and reddish brown, variously marbled with spots, blotches and wavy bands of dark brown or black. Belly pale ashy or greenish. Dewlap fine rich lustrous maroon (blackish in alcohol).

A single specimen only found resting upon the thatched roof of a native house. I was told that it was a species which was only rarely found. A most observant young Cuban, Lucio Alfonso, who was with me at the time, said that it was a lizard, very partial to thatched roofs. In general habit it resembles $A$. sagrei, but head, body, and limbs are much more slender.

Named for my friend, Dr. John Lewis Bremer, of the Harvard Medical School, who has often most kindly aided me while upon collecting trips. 


\section{Anolis luteosignifer Garman.}

Garman, Bull. Essex inst., 1888, 20, p. 4.

Boulenger, in the Zoological record, Reptiles, 1888, p. 9, questions the distinctness of this species from $A$. sagrei. Of the validity of the species there can be no possible doubt. The two forms may be recognized at once. A. luteosignifer has a snout almost flat instead of swollen in the internasal area, and hence a quite different profile from $A$. sagrei. The granular scales are not only much more uniform in size than in $A$. sagrei, but they also average smaller in size The types of A. luteosignifer (M. C. Z., No. 6,228) are in excellent preservation, and have been compared with a well-preserved series of $A$. sagrei which I collected near Santiago de Cuba.

The species is known only from Cayman Brac; but Maynard's notes show that this species, or some close ally, occurs also on Little Cayman. This is also said to be the only lizard on Cayman Brac.

\section{Anolis vermiculatus DUMÉRIL et BIBRON.}

Duméril et Bibron, Erpét. gén., 1837, 4, p. 128. Boulenger, Cat. lizards Brit. mus., 1885, 2, p. 41.

A large and striking lizard found only upon Cuba. Professor de la Torre gave me a young example from the Sierra de Guane, in Pinar del Rio. Messrs. Palmer and Riley found it at various localities in Pinar del Rio. Gundlach found it only near the source of the Rio Taco Taco, and remarked that when pursued, it took to the water. Thus it is evidently confined to the province of Pinar del Rio.

\section{Anolis loysiana Cocteat.}

Cocteau, Comptes rend Acad. roy. sci., 1836, 3, p. 226. Boulenger, Cat. lizards Brit. mus., 1885, 2, p. 42 .

One of the most peculiar species of the genus. It is confined to Cuba. I was until this year entirely unable to find this extremely well-marked species which Gundlach says has a wide distribution. He did not consider it rare and remarked that he always found it ensconced in crevices on the surface of the trunks of rough barked trees. I have recently secured a specimen from San Diego de los Baños from the U. S. national museum. In February, 1913, we collected a fine specimen in the village of Los Negros, Jurisdiction of Jiguani, Oriente, Cuba. It was on the rock of a small cliff beside the stream which has its source near the village. 


\section{Anolis argillaceus Cope.}

Cope, Proc. Acad. nat. sci. Phila., 1862, p. 176.

I have never succeeded in finding this species myself. Boulenger placed it in the synonymy of A. loysiana. Gundlach (Erpet. Cubana, 1880, p. 52), however, recognized it as a distinct species. After seeing the specimen which is preserved in the Gundlach collection in Havana I was strongly convinced that Gundlach was correct although as the cases are sealed the specimen could not be examined. On April 6 while collecting at Alto de la Union on Monte Libano near Guantanamo, Mr. C. T. Ramsden, found and sent me a lizard which proves to belong to this species and a comparison with $A$. loysiana makes it evident that they are not even very nearly related although the head seales are similar in general character. A. argillaceus is brilliantly marbled with yellow and dark brown about the head, has a rosy white dewlap, longitudinal dark brown bands on a speckled light brown field along the body, which is entirely without evidence of spines or tubercles. A. logsiana is perfectly lichen-like in coloration, very pale, ashy gray in general tone with very irregular and only slightly darker markings. A. loysiana is strongly depressed in habit, especially in life, while A. argillaceus is strongly compressed though stoutly built. Its habit recalls that of $A$. isolepis.

\section{Anolis semilineatus CopE.}

Cope, Proc. Acad. nat. sci. Phila., 1864, p. 171. Boulenger, Cat. lizards Brit. mus., 1885, 2, p. 68, pl. 5, fig. 1 .

This species is confined to Haiti; the only specimens in the collection are from the eastern extremity of the island across from Samaná, San Domingo. Boulenger records specimens in the British museum from San Domingo only, so that the species appeared to be localized in this region, until the receipt of ten examples from Diquini, Haiti collected by Mr. W. M. Mann.

\section{Anolis spectrum Peters.}

Peters, Monatsb. Akad. wiss Berlin, 1863, p. 136. Bodlenger, Cat. lizards, Brit. mus., 1885, 2, p. 69.

A rare species confined to Cuba. I know of it from the literature only. Gundlach, who has collected most if not all of the known specimens found it only near Matanzas and Cardenas. 
Anolis cyanopleurus Cope.

Cope, Proc. Acad.nat. sci., Phila., 1861, p. 211. Boulenger, Cat. lizards Brit. mus., 1885, 2, p. 69.

Another of the rare species confined to Cuba, and of which I have never been able to find a specimen.

\section{Anolis alutaceus Cope.}

Cope, Proc. Acad. nat, sci. Phila., 1861, p. 212. Boulenger, Cat. lizards Brit. mus., 1885, 2, p. 71.

Apparently a rare species; it was not represented in the Museum until on our trip in 1912 when we-secured a specimen at Madruga and one near Cienfuegos. In 1913 we got a fine series in the Sierra Maestra forests near Los Negros in the jurisdiction of Jiguani and a few specimens at Monte Libano near Guantanamo. The British museum did not possess a specimen at the time the second volume of the Catalogue of lizards was written. Gundlach (Erpet. Cubana, 1880 ; p. 49) also remarks that he has found but few examples of this species during his years of collecting. He adds that its range is not confined to any one part of the island and that it is a woodland species.

It is confined to Cuba.

\section{Anolis angusticeps Hallowelz.}

Hallowell, Proc. Acad. nat. sci. Phila., 1856, p. 228.

I have identified with this very imperfectly described species a large series of lizards some of which I caught at Los Negros, Baire, San Luis, Monte Libano, Pozo Prieto and other stations in the Province of Oriente, and many other specimens which Mr. C. T. Ramsden has sent me for study from a number of points about Guantanamo. I had at first named the adult males as a new species but the large material which I have studied now convinces me that all are referable to this species, first described from Cienfuegos and so poorly characterized that Boulenger was unable to guess at its validity or even to place it in the British museum Catalogue of lizards. When the first young examples were received from Mr. Ramsden I thought that possibly I had to deal with $A$. cyanopleurus, a species which I have never seen but this species has keeled ventral scales and the figure of the head given by Bocourt (Miss. sci. Mex. Reptil. pl. 16, fig. 29) indicates a very different species. The greatly enlarged scales on the ventral aspect of the tail and other characters agree well with Hallowell's diagnosis. The colors fall into the range which Gundlach described from two living specimens (Erpet. Cubana, 1880, p. 45). 
The species is confined to Cuba and the following notes will serve to make more clear its relationships.

It is closely related to $A$. homolechis, and has similar habits. It may be recognized at once in the field by its enormously developed gular sac, which in $A$. homolechis is pale white, while in this species it is carmine in the centre with a broad marginal band of brilliant yellow. Besides this, it may be distinguished by having fewer scales between the occipital shield and the superciliaries, and in having the scales which surround the occipital for some distance upon the upper temporal regions of a much smaller size. The canthus rostralis is separated from the frontal ridge by two or three rows of scales.

Altogether this species is very similar to $A$. homolechis in details of squamation. Without examining the type of $A$. homolechis, which is, according to Cope, in the British museum without locality, it is impossible to be perfectly sure that the species which I am naming now is not $A$. homolechis itself and the one with the white dewlap a new species. Cope's description is ambiguous, and the two forms with which I am dealing are obviously variable in many characters. Nevertheless, the dewlap color, which I have learned to regard as a very excellent one, divides them sharply into two groups. Cope mentions the dewlaps as being large. It is rather large in homolechis, but much larger in angusticeps. However, his note of the canthus as separated from the frontal ridge by but one row of scales, of the occipital as separated from the superciliaries by ${ }_{\lambda}$ many rows of scales, and by his mention of the metallic shades of the ventral surface would seem to fasten the name homolechis to the group of individuals having the white dewlap. This conclusion was reached last year by Dr. Stejneger and myself before I had this related form. That we are dealing with two distinct forms I have no doubt; but without an adequate description or a re-examination of the type, there is no use attempting to do more than call attention to the facts, and leave a more detailed discussion of status until the original type of homolechis can be examined.

\section{Anolis porcatus Gray.}

Gray, Ann. mag. nat. hist., 1840, 5, p. 112.

This extremely distinct species, which was figured by Cocteau in Sagra's Historia de Cuba, Reptiles, pl. 9, is confined to Cuba. It has very frequently been confounded with the North American A. carolinensis and the Bahaman A. brunneus. Even Boulenger, in the Catalogue of lizards, 1885, 2, p. 43, included it in the synonymy of $A$. carolinensis. 
Gray (loc. cit.) recorded the locality whence the species was supposed to have come by saying that it "Inhab. Cuba and Texas.". There is no doubt, however, but that the Cuban species was the one described.

It is abundant all over the island, occurring most commonly in gardens. It is especially fond of sitting on the plants which have long leaves, species of Pandanus, various bromeliacious plants and particularly upon agaves and aloes.

Anolis maynardi Garman.

Garman, Bull. Essex inst., 1888, 20, p. 7.

This species, which is confined to Little Cayman Island, differs markedly from $A$. porcatus of Cuba, its closest ally. Garman has mentioned the very long narrow snout, and the rather weak longitudinal rugae of the head, which separate the species from the shorter and more rugosely headed Cuban form. Of the two types (M. C. Z., No. 6,227), only one is in useful condition, the other having apparently been very badly dried and eaten by insects.

\section{Anolis brunneus CoPE.}

Cope, Proc. Acad. nat. sei. Phila., 1894, p. 432, pl. 10, fig. 3. Barbour, Proc. Biol. soc. Wash., 1911, 23, p. 49.

Even though it is not absolutely certain that the common green Anolis of the several Bahamas does not differ constantly upon the various islands, still at present it seems best for reasons already given (Barbour, loc. cit.) to consider these lizards together under this name, and so to distinguish them from their allies in Cuba, A. porcatus, and on the American mainland, A. carolinensis. Rosén, (Lunds univ. arsskrift, 1911, 7, no. 5, p. 30) although he had no Cuban material for comparison, nevertheless quite independently arrived at a somewhat similar solution of the vexed question regarding the status of these Bahaman lizards.

\section{Anolis oligaspis COPE.}

Cope, Proc. Acad, nat. sci. Phila,, 1844, p. 430, pl. 11, fig. 5.

This species was described by Cope from an imperfect female taken on New Providence Island. He compares it with A. krugi of Porto Rico, but remarks that he has not seen the latter. On my trips to New Providence I have never got this species, and have often doubted whether the type was not a displaced specimen, wrongly credited to the Bahaman fauna. When, also, however, Rosén's account of what he determined as Anolis porcatus appeared, it seemed at once probable that what he termed the "rare form" of this species was nothing 
more or less than Cope's A. oligaspis. A comparison of Rosén's poor figure (Lunds univ. arrskrift, 1911, 7, no. 5, p. 30, pl. 1-, fig. 8) with Cope's makes it appear as certain as possible under the circumstances that this species is an extremely rare one which occurs very sparingly on New Providence, whence the type came, and Andros Island, whence Rosén brought two specimens. These he confused with $A$. porcatus, which, in the Bahamas, should be called $A$. brunneus.

\section{Anolis leucophaeus Garman.}

Garman, Bull. Essex inst., 1888, 20, p. 109.

This species, of which the type (M. C. Z., No. 6,226) comes from Great Inagua, is by common consent considered the same as Cope's $A$. cinnamomeus (Proc. Acad. nat. sci. Phila., 1894, p. 435); and there seems to be no reason for not including his $A$. moorei also in the synonymy (loc. cit., p. 433).

\section{Anolis chlorocyanus Duméril et Bibron.}

Dumḱril et Bibron, Erpét. gén., 1837, 4, p. 117. Botlenger, Cat. lizards Brit. mus., 1885, 2, p. 44.

Garman (Bull. Essex inst., 1887; 19, p. 24) retained this species as distinct from A. coelestinus Cope (Proc. Acad. nat. sci. Phila., 1862, p. 177). An examination of his material, which consisted of two fine adults from Samana, San Domingo, the types of $A$. coelestinus (M. C. Z., No. 2,347), and three others which he collected at Tiburon, Haiti, forces the conclusion that these are really one and the same species, although it must be confessed that the head scales indicate that the specimens fall into two classes. There are, however, intermediates, and for this reason I do not feel justified in keeping the species distinct. Boulenger had already combined them. The form occurs upon Haiti only. Mr. Mann collected one example at Diquini, Haiti.

Anolis pulchellus DUMÉril et BiBron.

Duméril et Bibron, Erpét. gén., 1837, 4, p. 97. Stejneger, Rept. U. S. nat. mus. for 1902, 1904, p. 660, fig. 112-116.

Stejneger has shown that this species does not really come from Martinique, the type locality mentioned by Duméril and Bibron, since Plée, who sent the specimens to the Paris museum, sent them from Martinique, but collected in St. Thomas and San Domingo. The former was undoubtedly the type locality.

The species is known from Porto Rico, St. Thomas, St. Croix, Tortola, Just van Dyke, and Vieques. Garman records specimens collected by Ackermann at Port au Prince, Haiti; but Stejneger surmises, undoubtedly quite 
correctly, that these may have been shipped from Haiti, but collected elsewhere. There is no other Haitian record for the species. There is also a specimen in the U. S. national museum labeled "Nassau, New Providence"; but Stejneger has already noted that this was, of course, impossible, and that some mistake had occurred in the labeling.

\section{Norops ophiolepis (COPE).}

Cope, Proc. Acad. nat. sci. Phila., 1861, p. 211. Boulenger, Cat. lizards Brit. mus., 1885, 2, p. 26.

A not uncommon species, confined to Cuba. Several other species occur on the mainland of tropical America, but this is the only Antillean member of the genus. Its presence in Cuba serves to emphasize the fact that this island is far more intimately related to the mainland than any of the others.

My observations agree with those of Gundlach that this species is never arboreal, but is found only among grass or rushes, its non-climbing habits being correlated with the absence of subdigital lamellae. At Soledad, near Cienfuegos; this species was quite abundant in the tall grass of pasture land. It was difficult to catch owing to its habit of dropping to the ground and hiding quickly. It was also seen about Pinar del Rio, Madruga, and near Havana, where Mr. Samuel H. Scudder procured the only specimen the Museum had prior to our visits.

Iguana rhinolopha WIEGMANN.

Wiegmann, Herpet. Mexicana, 1834, p. 44. Gray, Cat. lizards Brit. mus., 1845, p. 186. Boulenger, Cat. lizards Brit. mus., 1885, 2, p. 190.

Iguanas were recorded from Grenada by Garman (Bull. Essex inst., 1887, 19, p. 50) as being intermediate between this species and I. tuberculata (Laurenti). A careful revision of these two species, made with the aid of extensive collections from many localities, will be necessary before their exact status can be settled. That they are really distinct I have no doubt whatever, but as yet their ranges can not be accurately defined. Stejneger suspects that if intermediates really do exist, they may be explained by the fact that the species have been carried about by ,human agency "in innumerable instances," and that the intermediates may be "hybrids from introduced stock, or because of their geographic distribution" (ex litt.). I favor the latter explanation, as apparently the accidental introduction of vertebrates by human agency is a far rarer phenomenon than is often realized.

Boulenger gives the distribution of what he calls Iguana tuberculata var. rhinolopha as Central America and West Indies. It was formerly widespread 
among the Antilles, but it has suffered great diminution in numbers on account of the ravages of the mongoose. It is so rare now in Grenada that neither Allen nor Brues were able to get a single specimen, although they offered rewards and searched for it diligently.

Reinhardt and Lütken record this species from St. Kitts and St. Lucia; Garman, from Grenada, Saba, and St. Thomas; and Boulenger, from St. Lucia.

Iguana delicatissima LAURENTI

Laurenti, Syn. Rept., 1768, p. 48. Boulenger, Cat. lizards Brit. mus., 1885, 2, p. 191.

This species has a curious, more or less haphazard distribution, since it occurs upon Swan Island, Nevis, St. Bartholomew, and St. Martins; and Boulenger includes "Brazil" within its range, based doubtless upon some wrongly labeled specimen. Reinhardt and Lütken record it from Martinique and Guadeloupe.

Cyclura cyclura (Cuvier).

Cuvier, Reg. anim., 1829, 2, p. 45. Coctead, Sagra's Hist. Cúba. Rept., 1838, p. 96, pl. VI.

This species is confined to Cuba, the Isle of Pines and the neighboring Cays. It has been confused by Boulenger with several well-marked forms. He has included C. carinata Harlan, from Turks Island, C. baeolopha Cope, of Andros Island, and C. collei Gray from Jamaica, in what, apparently for the sake of avoiding the repetition of the generic name, he calls $C$. carinata (Cat. lizards Brit. mus., 1885, 2, p. 193-195). The species from Turks, Andros Islands, and Watlings Island I know from examination to be well-defined species, and different from C.cyclura. This was pointed out by Stejneger when he described the Watlings Island Iguana (C. rileyi Proc. Biol. soc. Wash., 1903, 16, p. 129). At the time of writing the catalogue, Boulenger had only mounted specimens of the Jamaican Iguana; and lizards stuffed after the manner of half a century ago certainly lose their specific characters, as many stuffed reptiles in this Museum prove. But to judge from Gosse's description and beautiful figure, there can be no doubt but that the Jamaican species is as valid as the rest, which certainly are very distinct inter se. Dr. Stejneger recently told me that there is a Jamaican example in the United States national museum and that his examination of this specimen had shown it to be quite distinct from the others.

I have learned that this species is very rare upon the mainland of Cuba being only found in the most unfrequented localities. It has been exterminated over most of the island because of its excellence as an article of food. It is said still to be common on many of the Cayos lying off the coast of Cuba, especially 
Cayo Romano, and some cayos near Manzanillo. It also occurs about the Pan de Guajaibon, in the Sierra de Rangel, near Cabo San Antonio, Cabo Maisi, and Cabo Cruz. The Museum has a fine specimen from the region of Guantanamo given by my friend Mr. C. T. Ramsden and another from the hills near Santiago de Cuba collected by Capt. now Col. Wirt Robinson, U. S. A.

In 1888 Garman (Bull. Essex inst., 20, p. 105) recorded Cyclura nubita Gray 1831, from the Caymans. He simply quoted Maynard's field notes which read "The Iguana occurs commonly in the cliffs of both this island (Cayman Brac) and Little Cayman." In 1911 the Museum received from Mr. W. W. Brown the skin in alcohol of an Iguana from the Caymans with no data regarding the island whence it came. The head is badly shot but it appears to be a specimen of Cyclura cyclura. It is not fully adult. Unless the type is still well preserved Gray's C. nubila must be disregarded, the description is vague and no type locality is given.

\section{Cyclura collei GraY.}

Gray, Cat. lizards Brit. mus., 1845, p. 190. Barbour, Bull. M. C. Z., 1910, 52, p. 293.

Gosse (Proc. Zool. soc. London, 1848, p. 99, pl. 1) has contributed a beautiful plate and good diagnosis of this species, now so rare. His long and wellwritten account of its habits (loc. cit., and Naturalists' sojourn in Jamaica, 1851, p. 76-77) is as absorbing today as it was when first penned!

\section{Cyclura baeolopha Cope.}

Cope, Proc. Acad. nat. sei. Phila., 1861, p. 123. Barbour, Bull. M. C. Z., 1904, 46, p. 58. Stejneger, The Bahama Islands, 1905, p. 334. Rosê, Lunds univ. arsskrift, 1911, 7, no. 5, p. 37.

This and the various other species of this characteristic West Indian genus are probably all confined to the islands whence they have been described and perhaps to neighbouring islets. The range of each species is narrowly circumscribed; and the various species may easily be distinguished inter se by a careful reading of the descriptions, or better still, by comparisons of specimens. Boulenger unfortunately relegated to the synonymy of what he called Cyclura carinata Harlan (Cat. lizards Brit. mus., 1885, 2, p. 193) this as well as other valid species; whereas he applied Harlan's name to his Cuban and Jamaican specimens when in reality the name belonged to the species peculiar to Turk's Island.

Cyclura baeolopha is common about the central region of Andros Island, whence Bryant obtained an excellent series in 1904. Rosén did not find it in the northern part of the island. 
Bryant reported that the natives about the village at Mangrove Cay hunted the "guana" regularly with dogs as an esteemed article of food. I have, in fact, seen specimens brought to the market at Nassau on several occasions, - always said to be from Mangrove Cay. The natives twist loose one of the animals claws, and drawing out the sinew attached to it, are thus able to tie the animal's feet together over its back, so that it is helpless. In the markets at Panama heaps of helpless individuals of the common edible Iguana (Iguana iguana) may be seen any day tied up in this way, and they find a ready sale at from five to ten cents each (U. S. currency). The females full of eggs being most esteemed.

Cyclura rileyi STEJNEGER.

Stejneger, Proc. Biol. soc. Wash., 1903, 16, p. 129. Rosén, Lunds univ. arsskrift, 1911, 7, no. 5, p. 36.

Known only from Watling's Island. The field notes quoted by Stejneger show that C. V. Riley, who discovered this species, found it common on two small cays in the large saltwater lagoon on Watling's Island. The larger island of these two is known locally as Iguana Cay. This Museum's collection now contains one of Riley's original series.

\section{Cyclura cornuta (BonnaterRe).}

Bonnaterre, Tabl. encye. erpét., 1789, p. 40, pl. 4, fig. 4. Stejneger, Rept. U. S. nat. mus. for 1902, 1904, p. 670, fig. 122-126.

The Rhinoceros Iguana is found upon Haiti, Mona, and Navassa Islands. Stejneger has discussed the status of this species so fully that there is no object in going into it here, since no new material has come to hand. The question as to whether this name embraces more than a single species must be left until many additional specimens can be studied.

Cyclura carinata HARLAN.

Harlan, Journ. Acad. nat. sci. Phila., 1824, 4, p. 242, 250, pl. 15. Cope, Proc. U. S. nat. mus., 1887, 10, p. 437 .

A very distinct species, confined to Turk's Island. Stejneger and Rosén agree as to the status of this species, which was first pointed out by Cope with relation to its congeners. There is a topotype in the Museum collected by Prof. A. S. Bickmore, so that I have been able to make an actual comparison with some of the other species. 
Leiocephalus carinatus Gray.

Grax, Philos. mag., 1827, 2, p. 208. Bodlenger, Cat. lizards Brit. mus., 1885, 2, p. 165. Barbour, Bull. M. C. Z., 1904, 46, p. 58. Rosén, Lunds univ. arsskrift, 1911, 7, no. 5, p. 35-36.

A rather wide ranging form. Cuban and Bahaman individuals seem to be indistinguishable. Known from Cuba, Great Bahama, Great Abaco, Stranger Cay, New Providence, Andros, Cat, and Crooked Islands.

In Cuba, as in the Bahamas, this is a species characteristic of the zone of vegetation bordering the ocean beach. It is very common, living in burrows in the masonry of the walls of Morro Castle and Cabañas Fortress at Havana, and at the Morro of Santiago de Cuba, as well as at the forts on the foreshore near Matanzas.

Leiocephalus virescens STEJNEGER.

Stejneger, Proc. U. S. nat. mus., 1900, 23, p. 471. RosếN, Lunds univ. arsskrift, 1911, 7, no. 5, p. 35.

A local race confined to Green Cay, south of New Providence Island, derived from $L$. carinatus.

\section{Leiocephalus varius GARMAN.}

Garman, Proc. Amer. phil. soc., 1887, 24, p. 274.

The types of this species are in the collection, well preserved (M. C. Z., No. 6,023). It is confined to Grand Cayman. On Cayman Brac Garman recorded $L$. carinatus, but these specimens are not quite typical of that species. No member of the genus has been taken on Little Cayman.

\section{Leiocephalus loxogrammus CoPE.}

Cope, Proe. U. S. nat. mus., 1887, 10, p. 437.

The type of this species came from Rum Cay, collected by the naturalists of the U. S. F. C. S. Albatross. It was later taken at the same island by Maynard and recorded by Garman. (Bull. Essex inst., 1888, 20, p. 13). More recently still Stejneger has reported it from Watling's Island. It is not known elsewhere, but may be looked for upon others of the Bahamas as yet herpetologically unexplored.

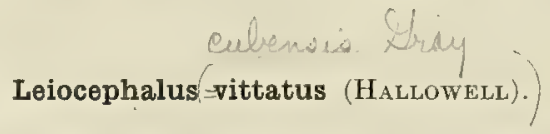

Halloweld, Proc. Acad. nat. sci. Phila., 1856, p. 151. Boolenger, Cat. lizards Brit. mus., 1885, 2, p. $163-164$.

In 1909 I found this species very abundantly about Camaguey (Puerto Principe) Cuba, and a series was obtained there. The Museum had other 
specimens from Matanzas and Havana, but most unfortunately none from San Domingo. I am unable to make comparison of Cuban and San Domingan examples, which Boulenger groups together. It is confined to these two islands, if the San Domingan records are not based on the young of $L$. personatus, which look quite similar to this species.

In 1912 I found the species much more widespread than I had imagined and specimens were secured from Havana, several localities in the Province of Pinar del Rio, about Cienfuegos, near Madruga, Bayamo, Guantanamo and elsewhere. The species was observed almost everywhere except in the immediate vicinity of the seacoast where its place is taken by L. carinatus. Its most characteristic habitat is perhaps in the guarda rayas of the cane fields.

\section{Leiocephalus macropus CoPE.}

Cope, Proc. Acad. nat. sci. Phila., 1862, p. 184. Boulenger, Cat. lizards Brit. mus., 1885, 2, p. 163.

This seems to be a rare species confined to eastern Cuba. It was not represented in the collection until Capt. Wirt Robinson presented two specimens taken by him near Santiago after the American occupation.

Cope (Proc. U. S. nat. mus., 1887, 10, p. 438) says, "Boulenger, in the Vol. II of the Catalogue of the lizards in the British Museum, regards $L$. raviceps as the same as L. macropus. They are, however, different species, belonging to different sections of the genus." Boulenger did not place $L$. raviceps as a synonym of $L$. macropus, but of $L$. vittatus, a course apparently justified.

Leiocephalus schreibersii (Gravenhorst).

Gravenhorst, Nova acta Acad. caes. leop.-carol., 1836, 18, p. 739, pl. 54, fig. 15-16. Boulenger, Cat. lizards Birt. mus., 1885, 2, p. 162.

A very well-marked species known from Haiti and Great Inagua. There are specimens in the Museum from both localities. Mann's recent series adds seven from Manneville, Haiti.

Leiocephalus melanochlorus COPE.

Cope, Proc. Acad. nat. sci. Phila., 1862, p. 184. Boulenger, Cat. lizards Brit. mus., 1885, 2, p. 164.

The typical series, about twenty examples collected near Jeremie, Haiti, by Dr. Weinland (M. C. Z., No. 3,598), is still well preserved. Other specimens have come from Puerto Plata, San Domingo, collected by Mr. M. A. Frazar, and from Furcy, Haiti, collected by Mr. W. M. Mann. Known only from this island. 
Leiocephalus personatus COPE.

Cope, Proc. Acad. nat. sci. Phila., 1862, p. 182. Boulenger, Cat. lizards Brit. mus., 1885, 2, p. 164.

The striate head scales and other characters, as well as the absence of the white lateral band or series of white spots, make one feel justified in keeping this species separate from L. vittatus, although Boulenger remarked (loc. cit.) that they were perhaps not specifically distinct. The solution to be expected would be that this species replaced $L$. vittatus on San Domingo; one having no specimens of $L$. vittatus from San Domingo would form this view. Boulenger, however, recorded such specimens in the British museum; but it is possible that these are really referable to $L$. personatus. At the time of writing the Catalogue, he had only one Cuban $L$. vittatus for comparison.

The types of this species (M. C.Z., No. 3,615) are two examples in fair preservation. More recently we have received it from Puerto Plata, San Domingo, and from Furcy, Haiti. Cope based his species L. trigeminatus on the young of this species, as he himself admitted (Proc. U. S. nat. mus., 1887, 10, p. 438), after Boulenger had placed $L$. trigeminatus in the synonymy of $L$. personatus. Although both species were described from Weinland's material, and the types of both were said by Cope to be in the Museum of Comparative Zoölogy, nevertheless the types of $L$. personatus only are to be found.

\section{Leiocephalus eremitus Cope.}

Cope, Proc. Acad. nat. sci. Phila., 1868, p. 122. Boulenger, Cat. lizards Brit. mus., 1885, 2, p. 165.

A species confined to the small island of Navassa, near Haiti.

Leiocephalus herminieri (DUMÉRIL et BIBRoN).

Dumfril et Bibron, Erpét. gén., 1837, 4, p. 261. Boulenger, Cat. lizards Brit. mus., 1885, 2, p. 166.

This species was said by Duméril and Bibron to have been sent to the Paris museum from Trinidad by l'Herminier, and from Martinique by Plée and Guyon. Boulenger had only a skeleton from Martinique. Whether this creature has been extirpated by the mongoose or not it is impossible to say. It is not represented in Garman's collection from Martinique, nor does it appear to have been recorded from there in recent years. It is not known from any other of the Lesser Antilles, which would make it seem possible that it was a Trinidad species that had been erroneously credited to the fauna of Martinique. 
Celestus sagrae Cocteau.

Coctead, Sagra's Hist. Cuba, Rept., 1838, p. 180, p. 20. Boulenger, Cat. lizards Brit. mus., 1885, 2, p. 293.

A species of which little is known. It is confined to Cuba. The only examples which I have seen have been two, one obtained by exchange from Dr. Stejneger of the U.S. national museum, which came from eastern Cuba. This was the locality indicated for most of the collection of Mr. Charles Wright which was made in the Sierra de Yateras, near Guantanamo. The second specimen was given me by my friend, the Cuban botanist, Sr. Jesus Valdivia, whom I have to thank for many favors. It was caught near the city of Havana. Mr. William Palmer wrote me that he had met the species once in the Vuelta Abajo region near San Cristobal. Gundlach mentions that the species is rare and unknown to many natives. Those who know it call it "Culebrita de quatro patas," the four-footed snake.

\section{Celestus sepoides (GrAY).}

Gray, Ann. mag. nat. hist., 1852, ser. 2, 10, p. 281. Boulenger, Cat. lizards Brit. mus., 1885, 2, p. 294.

This species, the only Celestus having four toes, has twice been named as the type of a genus peculiar to Haiti. Once it was called Sauresia by Gray (loc. cit.); and ten years later it was redescribed by Weinland as Enbryopus habichii. (Abhandl. Senck. naturf. gesellsch., 1862, 4, p. 132, pl. 5, fig. 1).

* If this species occurred upon the mainland, the possession of four toes would be quite sufficient for the erection of a genus to contain it; but for the Haitian lizard, such a course only masks its relationships. It is in all other respects a Celestus pure and simple, and represents the modified descendants of individuals, left isolated in Haiti, whose relatives in Cuba have become Celestus sagrae, and in Porto Rico, C. pleei. It should stand in the genus between these two species.

Not recognizing this genus, I may be considered as inconsistent after what I have said regarding keeping separate $C$. crusculus and $C$. costatus. To me it seems that letting this distinction stand, we are going to just as unreasonable an extreme as when several valid species are thrown together simply because they look very much alike. Here we are over-emphasizing an isolation which is just what Günther has warned against when by merging species we may easily over-emphasize the relationships of the islands represented by the material being studied. Günther and Boulenger,- the latter in handling Cyclura, for 
example,- have perhaps quite unconsciously over-emphasized the closeness of the relationship of the Antilles with one another.

The name Sauresia may be retained as a subgeneric heading, if it is desirable to point out the fact that the Haitian individuals of this group of individuals have become more modified in structure from the generic type than have the individuals on Cuba and Porto Rico.

Celestus pleii (Duméril et Bibron).

Duméril et Bibron, Erpét. gén., 1839, 5, p. 605. Stejneger, Rept. U. S. nat. mus. for 1902, 1904, p. 622 .

A species rare, like all the others in the genus, because its ground-inhabiting nature makes it an easy prey for the marauding mongoose. Stejneger has shown that the type locality was beyond doubt erroneous (it was given as Martinique), and that the species is confined to Porto Rico.

Celestus impressus CoPE.

Cope, Proc. Acad. nat. sci. Phila., 1868, p. 127. Barbour, Bull. M. C. Z., 1910, 52, p. 298.

A species which is still fairly abundant in the hilly country about Mandeville in Jamaica. It is confined to that island.

Celestus occiduus (SHAw).

SHAw, Zoology, 1802, 3, p. 288. Barbour, Bull. M. C. Z., 1910, 52, p. 294.

In my Notes on the herpetology of Jamaica, I included within this species C. striatus (Gray), and C. hewardii (Gray). These species, probably on account of very deficient material, had been considered distinct since their description, and confined to Jamaica.

Garman (Bull. Essex inst., 1887, 19, p. 21) says that a "careful study of the type of Cope's $D$. stenurus convinces me that Dr. Boulenger is right in placing it in D. striatus." The type of Cope's Diploglossus stenurus, from Jeremie, Haiti (M. C. Z., No. 3,612), is a very large individual, for a long time the only Haitian specimen of the species in the collection. It agrees closely with the description given by Boulenger (Cat. lizards Brit. mus., 1885, 2, p. 289, pl. 16, fig. 1) for Diploglossus striatus, which I believe to represent only a variation of Celestus (Diploglossus) occiduus (Shaw). If, however, the small auditory opening of which Boulenger speaks in his description of $C .(D)$. striatus is really constant, then the individuals having it may be entitled to specific rank. The ear opening is small in the type of $C$. stenurus (Cope); but this character shows itself 
to be somewhat variable in the species, which is represented in the collection by good series of examples. The dorsal scales in Cope's type have a slight tendency toward mucronate condition. This may be due to old age; but if it proves to be constant, and if it never occurs in senescent Jamaican individuals, the Haitian form is really distinct. Unfortunately no such old Jamaican example is at hand. Until the accumulation of much additional Haitian material it is better to keep the forms separate. Mann's two recent examples from Diquini are not old individuals and do not settle the question of the identity or distinctness of these two species.

\section{Celestus rugosus CoPE.}

Cope, Proc. Amer. philos. soc., 1879, 18, p. 272. Boulenger, Cat. lizards Brit. mus., 1885, 2, p. 288.

This species seems to represent $C$. occiduus (Shaw), of Jamaica, upon San Domingo; as $C$. costatus Cope represents $C$. crusculus Garman. Boulenger, judging from Cope's description, - a course which I also have to follow, - allowed C. rugosus Cope to stand as a distinct species. There is no specimen in the collection here; but the form seems to be a perfectly valid one, confined to San Domingo.

\section{Celestus crusculus (GARMaN). \\ Garman, Bull. Essex inst., 1887, 19, p. 22. Barbour, Bull. M. C. Z., 1910, 62, p. 295.}

Another beautiful species (Type M. C. Z., No. 6,051) which is apparently disappearing fast. It is found only upon Jamaica.

In the Zoological record for 1888 Boulenger raised the question as to whether this species was not Diploglossus phoxinus Cope (a species which should really stand as Celestus costatus (Cope). As stated under the caption of this species, I think pending the accumulation of more material these species should be kept separate. Günther (Ann. mag. nat. hist., 1888, ser. 6, 2, p. 364-65) believes we should be most careful about admitting that the West Indian Islands are populated by related but peculiar species. On commenting on Garman's work in naming many of these island forms, he says: "In this case any one studying the distribution of reptiles over the West Indies would, by relying upon statements such as are propounded by Mr. Garman in his recent [1887-1888] publications on West Indian reptiles be misled into the view of a more complete isolation and specialization of the faunas of the various islands than obtains in reality." It is in just this point of view that Günther errs deeply. It is this very close relation of the insular faunae that we must be most cautious not to exaggerate. The presence of the same species upon neighboring islands is very significant 
when true. The presence of allied species upon neighboring islands is what experience with West Indian reptiles teaches one to expect. To say that these Celesti upon Jamaica and Haiti are the same when one can not be certain of this from the material at hand is misrepresenting the state of affairs far more probably than to hold them separate, when we find so few species really the same upon the two islands, and so many types, if one may call them such, represented on each of the two islands by related species. We are erring more when we overemphasize the similarity of the fauna of Jamaica and of Haiti; for the relationship shows in its truest light when the differences between the species on the islands are pointed out and held at their true value.

I pointed out in 1910 (loc. cit.). that Boulenger's Diploglossus bakeri was apparently this species. For the use of Celestus instead of Diploglossus, consult the same paper.

\section{Celestus maculatus (GARMaN).}

Garman, Bull. Essex inst.; 1888, 20, p. 105.

Boulenger, in the Zoological record for 1888, erroneously noted that this species was a synonym of $C$. striatus (Gray) ( $=C$. occiduus Shaw). Garman correctly pointed out its relationship to his $C$. crusculus. It needs comparison with no other species. It may be separated at once from $C$. crusculus; and plenty of specimens, including the type, of this species are available for comparison. The second and third digits are, as Garman pointed out, much elongated. They are, in fact, nearly twice as long as those in any specimen of $C$. crusculus of the same size.

The type is unique in the collection (M. C. Z., No. 6,231). It was collected on the island of Cayman Brac. It is possible that the species might occur upon other islands of the Cayman group.

Celestus costatus (COPE).

Cope, Proc. Acad. nat. sci. Phila., 1861, p. 494. Garman, Bull. Essex inst., 1887, 19, p. 23.

Garman (loc. cit.) was the first to point out that the type of Cope's Panalopus costatus was in reality a mutilated lizard of the same species, a perfect specimen of which Cope later characterized as Celestus phoxinus. The earlier type (M. C. Z., No. 3,606) was described as representing a strange genus having legs without toes. I believe that a partly healed up groove around the lizard's body offers the key to why it was so mutilated. Some young Haitian caught the lizard and tied a string tightly about its body, hence the groove; then he proceeded to snip off the fingers and toes - a form of amusement, or perhaps experimentation, not unknown to more civilized youth. The lizard then escaped, and 
the limb stumps healed over. Finally, Dr. D. F. Weinland collected the lizard, in due time it became the type of a supposed new genus.

This imperfect specimen, however great its historic value, is almost worthless for purposes of comparison with C. crusculus Garman, from Jamaica, its very close ally. I believe it most unwise to conclude that these two species are identical until a comparison can be made, based on more extensive collections from Haiti. I have given reasons for wariness in making such conclusions under the heading of $C$. crusculus Garman (p. 305).

If the toes had been cut off the type of $C$. maculatus, it would be quite indistinguishable from the type of $C$.crusculus; but with the feet perfect, the species may be recognized at once. Some such character may exist in $C$. costatus.

Cope said, when describing Celèstus phoxinus, (Proc. Acad. nat. sci. Phila., 1868, p. 125) that "This elegant species was found by Dr. D. F. Weinland, near Jeremie, Hayti, and was placed by him in the Museum of Comparative Zoology, Cambridge, Mass., in care of Prof. Agassiz." I have been quite unable to locate the type, nor do I know whether Garman had it for comparison with C. costatus when he announced the identity of the two species.

\section{Cricosaura typica GUNDLACH \& PeTers.}

Gundlach \& Peters, Monatsb. Akad. wiss. Berlin, 1863, p. 362, pl., fig. 1-6. Bocourt, Miss. sci. Mex. Reptil., p. 313, pl. 20, fig. 14-18. Boulenger, Cat. lizards Brit. mus., 1885, 2, p. 329.

This remarkable archaic monotypic genus has for herpetologists an interest equivalent to that which is held for Solenodon among students of mammals. Its excessive rarity, there does not seem to be a single example preserved in an American museum, outside of Cuba, makes it the most-to-be-desired booty of any naturalist who may collect in Cuba.

On the continent, its allies of the genus Xantusia were almost equally rare until it was found that $X$. vigitis Baird lived by day among the drooping dead leaves of the great tree yuccas of our southwestern deserts (Van Denburgh, Occ. papers Cal. acad. sci., 1897, 5, p. 123-128). Xantusia henshawi Stejneger lives among granite boulders, and can be found for a few moments before dark only, as it does not come out from its hiding place until after sundown.

Lepidophyma, the only other genus of the Xantusiidae is also semi-nocturnal. Sumichrast is quoted by Bocourt (Miss. Sci. Mex. Reptil., p. 311-312) as saying that it lives in the darkest humid forests. Its habits are somewhat like those of a gekko, living in the decayed galleries, or in the crevices of old tree trunks, much more rarely among rocks. It is never seen abroad by day; but nevertheless is not really rare, once one knows where and how to search for it. 
There can be no doubt but that the habits of Cricosaura are somewhat similar to those of Xantusia and Lepidophyma.

It has been customary to consider the members of this family as types reminiscent of a fauna which has almost passed. The rarity of the individuals of the various species has been brought forward as an argument that they are in fact dying out. In view of the real abundance of the creatures when once their hiding places become known, this argument ceases to be weighty. The scattered ranges of the various forms, each narrowly circumscribed, and the structure of the animals show that the group is, to be sure, an archaic one. The surviving species seem, however, to have adapted themselves to a mode of life successful under present conditions. Gundlach (Erpet. Cubana, 1880, p. 63) found all the specimens known under stones near Cape Cruz, the southernmost point of the island. This is all that is known of the habits of the species.

All of the foregoing was written before I visited Cuba again during 1913. This trip included a special, and somewhat arduous, excursion to Cabo Cruz. Prof. de la Torre and I went together and he had with him Gundlach's manuscript field notes which give in minute detail the exact places at each locality visited where Gundlach's actual collecting was carried on. By means of this I was able to go to what I believe was the exact spot where Gundlach got his specimens and to find again this most interesting form. I only got one example under a large stone about one hundred yards a little north of east from the lighthouse. Here there is a small area which is sunken and where red earth occurs with scattered fragments of the country rock of limestone. The surroundings are sandy toward the point of the Cape and "diente perro" to the North and East. Cacti and plants which are excessively thorny recall the habitat of Xantusia on the mainland.

The species is more active than I had expected to find it and two specimens were unfortunately lost by Cubans who were helping look for it, as they escaped into crevices in the outcropping limestone here eroded into spear points and knife blade edges which ring like metal, as one walks over them and which makes this "diente-perro" country anathema to all Cubans.

\section{Centropyx intermedius Gray.}

Gray, Griffiths Cuvier's Animal kingdom, 1830, 9, Syn. reptil., p. 31. Boulenger, Cat. lizards Brit. mus., 1885,2 , p. 340 .

Cope first recorded this species from Barbados; and I cannot find the slightest difference between specimens from Barbados and the description of main- 
land specimens, - I have none for actual comparison. Fielden (Zoologist, 1889, p. 297) contributes an excellent account of this species, its habits, etc. It occurs also in the Guianan subregion of South America.

Garman's name, C. copii, based upon three specimens M. C. Z., No. 6,076 from Barbados, has no standing in nomenclature, since it is a nomen nudum.

Amoiva auberi Cocteau.

Cocteau, Sagra's Hist. Cuba. Rept., 1843, p. 74, pl. 6. Botlenger, Cat. lizards Brit. mus., 1885, 2, p. 356 .

This species is widespread in Cuba, to which island it is confined. There are specimens in the Museum from Santiago, Bahia Honda, and Puerto Principe. Near the latter town I found it very common, running about over the sun-baked ballast of the railroad line. Like its congeners, it prefers open, dry plains, with plenty of exposed rock for basking. On my last trip to the island I found it common near the beach between Morro Castle and Cojimar near Havana, and met with it sparingly at San Diego de los Baños, Herradura, Pinar del Rio, and Madruga.

\section{Ameiva dorsalis Gray}

Gray, Ann. mag. nat. hist., 1838, 1, p. 277. Boulenger, Cat. lizards Brit. mus., 1885, 2, p. 357. BarBour, Bull. M. C. Z., 1910, 52, p. 298.

An interesting species, confined to the island of Jamaica, where it has grown rare and difficult to obtain owing to the reptile-devouring habits of the introduced mongoose.

\section{Ameiva thoracica Cope.}

Cope, Proc: Acad. nat. sci. Phila., 1862, p. 64. Boulenger, Cat. lizards, Brit. mus., 1885, 2, p. 356. Rosén, Lunds univ. arsskrift, 1911, 7, no. 5, p. 37.

A common species throughout its range, which includes the Bahaman Islands of New Providence, Eleuthera, and Andros. Cope (Proc. U. S. nat. mus., 1887, 10, p. 438) records a specimen taken by Townsend (Cruise of the Albatross), at Great Abaco. Its occurrence on this island is nevertheless problematical. In 1904, Allen, Bryant, and I searched diligently for it at various stations on the island, without result.

\section{Ameiva chrysolaema Cope.}

Cope, Proc. Acad. nat. gci. Phila., 1868, p. 127. Bodlenger, Cat. lizards Brit. mus., 1885, 2, p. 355.

Confined to Haiti; a distinct form, related to the Bahaman A. thoracica. Mr. W. M. Mann obtained many examples near Manneville. 
Ameiva taeniura COPE.
Cope, Proc. Acad. nat. sci. Phila., 1862, p. 63. Boulenger, Cat. lizards Brit. mus., 1885, 2, p. 350.

The types, three fine specimens (M. C. Z., No. 3,614), were the only examples in the collection until the receipt of many from Diquini and Manneville collected by Mr. W. M. Mann. The species is confined to Haiti.

Ameiva vittipunctata Cope.

Cope, Proc. Acad. nat. sci. Phila., 1871, p. 220 . Boulenger, Cat. lizards Brit. mus., 1885, 2, p. 355.

The types of this species came from near the city of San Domingo. Recently, however, the Museum has received a fine suite of specimens from Momance, Diquini, and Manneville, collected by Mr. W. M. Mann.

\section{Ameiva maynardi Garman.}

Garman, Bull. Essex inst., 1888, 20, p. 110.

This form, derived from Haiti, occurs upon Great Inagua in the southern Bahamas. The types are M. C. Z., No. 6,225.

Ameiva exul Cope.

Cope, Proc. Acad. nat. sci. Phila., 1862, p. 66. Stejneger, Rept. U. S. nat. mus. for 1902, 1904, p. 612, fig. 59-66.

This ground lizard is rather more wide-ranging than many of the species of the genus. Various students, notably Stejneger, have compared specimens from the different islands; and they find them apparently indistinguishable upon Porto Rico, Vieques, St. Thomas, St. John, St. Croix, and Water Island. Nevertheless, Garman (Bull. Essex inst., 1887, 19, p. 11) says, "Porto Rico specimens appear to be a little lighter in color, more red on the back and head, and have the whitish frecklings on the hinder part of the body and the base of the tail, as also the dark spots along the flank, less numerous and more distinct than those from St. Thomas. The latter have the colors a trifle darker, more olive, and the white spots and the black spots less faded." I have re-examined the specimens, now more than twenty years older than when Garman studied them, and I find the difference to be really striking. The series are probably very different in life, and probably represent groups of individuals strongly tending toward the formation of distinct species by isolation, by the constantly increasing tendency of an isolated group of individuals to vary according to latent peculiarities which become in succeeding generations increasingly patent. 
Stejneger, however, with an enormous series of Porto Rican specimens, emphasizes the great variability in coloring which he finds.

\section{Ameiva alboguttata Boulenger.}

Boulenger, Jahresb. Naturw, verein Magdeburg, für. 1894-1896, 1896, p. 112. SteJNeger, Rept. U.S. nat. mus. for 1902, 1904, p. 618, fig. 67-72.

A species evolved through the isolation on Mona Island of individuals similar to those which gave rise, on Porto Rico, to A. exul.

Ameiva lineolata Duméril et Bibron.

Duméril et Bibron, Erpét. gén., 1839, 5, p. 119. Boulenger, Cat. lizards Brit. mus., 1885, 2, p. 349.

A beautiful species, confined to Haiti, where good series were collected by Dr. Weinland, near Jeremie, and by Mr. Frazar, near Puerto Plata, at the opposite extreme of the island. This would suggest that it occurs widely spread.

Ameiva polops COPE.

Cope, Proc. Acad. nat. sci. Phila., 1862, p. 66. Boulenger, Cat. lizar ds Brit. mus., 1885, 2, p. 350.

A well-defined species, confined to the island of St. Croix.

Ameiva wetmorei STEJNeger.

Stejneger, Proc. Biol. soc. Wash., 1913, 26, p. 69.

This species so recently discovered stands directly with the lineolata-polops group and serves to bridge the long supposed discontinuity of the range of these allied species. The finding of this important lizard as Stejneger says "illustrates once more the fortuitous nature of reptile collecting." Porto Rico, the island whence this species comes was of all the Antilles presumably the best known.

Ameiva corvina COPE.

Cope, Proc. Acad. nat. sci. Phila., 1861, p. 312. Boulenger, Cat. lizards Brit. mus., 1885, 2, p. 358.

The type of this species is a single specimen from the island of Sombrero (M. C. Z., No. 5,532). It has since been taken upon Anguilla Island, whence the British museum had specimens (Boulenger, loc. cit.). Garman (Bull. Essex inst., 1887, 19, p. 10) mentions that between the type and specimens "from Haiti there is apparently little difference." This is perfectly true; but there can be no doubt that M. C.Z., No. 3,616, four specimens said to have been taken at Jeremie, Haiti, by Weinland, are really not from Haiti. The catalogue refers to their having had an "old number"; and probably in the process of re- 
cataloguing, or while sent to Cope for identification, they may have been mixed with Weinland's collection, and finally labeled "Haiti."

Ameiva atrata GARMAN.

Garman, Bull. Essex inst., 1887, 19, p. 8.

This is a distinet species, related to A: corvina, but confined, so far as known, to the island of Redonda. The type is M. C. Z., No. 6,084.

Ameiva analifera Cope:

Cope, Proc. Amer. philos. soc., 1869, 11, p. 158.

This species is allied to $A$. pleei, of Martinique, and through it to A. surinamensis. The types came from St. Martins and St. Bartholomew. The Museum has a number from the latter island.

Ameiva garmani, sp. nov.

Type:-No. 6,141, M. C. Z., Anguilla, F. Lagois, collector.

In 1887 Garman noted, but did not describe, this specimen from Anguilla as a variety of $A$. analifera Cope. A re-examination of the specimens of Cope's A. analifera, from St. Bartholomew, shows that A. garmani differs from the other examples in several characters which the series from St. Bartholomew show to be constant. These differences, taken in connection with the very markedly different coloration, prove that the Anguilla form constitutes a distinctly valid species. In species of Ameiva, the unvarying color pattern and color of individuals of the same age is an excellent diagnostic character.

Ameiva garmani is similar to $A$. analifera Cope, but differs in the following characters:- median gulars larger on the average in $A$. garmani than in $A$. analifera, and differently arranged, in that large and small scales occur irregularly, while in the St. Bartholomew specimens the scales are evenly graded in size, and are regularly arranged. In A. garmani, the largest of the outer tibials is very different in size from that of the other species, being not only larger, but having its vertical and horizontal dimensions almost equal, while in the other specimens this scale is much longer than high. There are corresponding differences in size and position of the other enlarged tibials owing to their filling an area about a scale of such different character. As Garman (Bull. Essex inst., 1887, 19, p. 10) said, this species is "easily distinguished" from its ally "by the color; lighter brown anteriorly, with large light gray or olive spots posteriorly, which gives the hind legs the appearance of being gray reticulated with brown," in- 
stead of dark brown with gray fleckings as seen in the other species. The tail is light brown, much blotched with gray, and with scattered black dots covering a scale each, instead of dark brown with quite widely scattered light specks.

\section{Ameiva erythrops Cope}

Cope, Proc. Acad. nat. sci. Phila., 1871, p. 221.

Garman remarks that this form "is not entitled to more than varietal distinction"; nevertheless, owing to the fact that this is an insular race, and that there can never be any geographic continuity of ranges, a binomial is employed for its designation. It is confined to St. Eustatius. Boulenger (Cat. lizards Brit. mus., 1885, 2, p. 359) considers this a synonym of Gray's A. punctata and A. major, for he considers these both one species. The types of these forms came from the Guianas, and those examined by Duméril and Bibron (Erpét. gén., 1839, 5, p. 117) came from Cayenne and Trinidad; so that this species may be at once erased from the Antillean list, as specimens from Guiana and St. Eustatius might reasonably be surmised to be specifically distinct.

Ameiva erythrocephala (DAUDIN).

Daddin, Hist. nat. rept., 1802, 3, p. 22 . Garman, Bull. Essex inst., 1887, 19, p. 9.

Daudin expressly states that his description is based on specimens from the island of St. Christopher, whence came the large series upon which Garman reported. Boulenger in the Zoological record for 1887, says that this is what he called A. punctata. I have discussed this mainland species under A. erythrops Cope (ante). If this lizard from St. Eustatius should prove to be the same as that from St. Christopher, then Daudin's name is applicable for both, a fact which Boulenger overlooked when writing the catalogue. There are no specimens from St. Eustatius in the collection; but from description, I judge the species found there to be distinct, though very closely related.

Ameiva pleii DumérIL et BiBron.

Duméril et Bibron, Erpét. gén., 1839, 5, p. 114. Bodlenger, Cat. lizards Brit. mus., 1885, 2, p. 354.

A species confined to Martinique. It is related to the South American $A$. surinamensis.

\section{Ameiva pluvianotata Garman.}

Garman, Bull. Essex inst., 1887, 19, p. 6.

A beautiful species, from Montserrat. The types are M. C. Z., No. 6,086. 
Ameiva fuscata Garman.

Garman, Bull. Essex inst., 1887, 19, p. 5.

This fine lizard is confined to the island of Dominica. The types are M. C.Z., No. 6,087. Günther (Ann. mag. nat. hist., 1888, ser. 6, 2, p. 363) says of this species, "Closely allied to A. surinamensis; the Dominica form may be kept distinct on account of the modified scutellation of the fore and hind feet. The large scutes of the forearm are separated from the rows of scutella of the toes by broad areas of very minute scales." From this, it will be seen that the species is a very distinct one:

\section{Ameiva aquilina Garman.}

Garman, Bull. Essex inst., 1887, 19, p. 3.

This species is really close to $A$. surinamensis, as would be expected from the situation of the islands which this species inhabits, Grenada and St. Vincent. The greater number of femoral pores and a number of other characters, some of which, though perhaps not all, may be found diagnostic in each individual, so that the specimens may always be separated quite easily. The types are M. C. Z., No. 6,088 and 6,089.

Dr. Allen procured eight specimens, mostly about St. George, Grenada. He was told by local observers that some years ago the species almost disappeared on account of the mongoose, but that at the present time it appeared to be gaining considerably in numbers. This is very interesting, since I learned in Jamaica that exactly the same thing had occurred there, with Ameiva dorsalis Gray. This would indicate that some sort of a balance is being reached, compensating for the introduction of the mongoose. The lizards may have gradually changed their habits, though this does not appear from field observations; or they may have grown shyer. They are certainly very wary now, and can usually be got only by shooting.

Tiaporus fuliginosus CoPE.

Cope, Proc. Amer. philos. soc., 1892, 30, p. 132, pl.

This lizard, which Cope states stands in the same relation to Ameiva as Monoplocus does to Centropyx, is said to have been found only on Swan Island. The monotypic genus is thus very narrowly restricted. I had the opportunity to study the types at the U.S. national nuseum, by the courtesy of Dr. Stejneger.

Since this was written Mr. George Nelson has made several collecting trips to Swan Islands. He reports that no such lizard as this Ameiva-like Tiaporus exists on the Islands. The Jamaicans and Cayman Islanders living at Swan 
Island do not know of any such species, though they are thoroughly familiar with the local fauna. This ground inhabiting species has probably been exterminated by the introduced cats. No cats are found feral upon Little Swan Island, only upon Swan Island, but the lizard may have occurred upon this island only.

\section{Scolecosarus alleni, sp. nov.}

Plate, fig. 11-15.

The fact that this curious burrowing teid genus occurred on Grenada was first made known by Garman (Bull. Essex inst., 1887, 19, p. 12). He obtained a single specimen there, and identified it with Scolecosaurus cuvieri Fitz. As a matter of fact, this name should really stand as Scolecosaurus cuvieri (Dum. and Bibr.), all previous references to the species being nomina nuda, or unrecognizable descriptions. A careful examination of the seven specimens obtained by Allen and Brues shows that, as might well be expected, the Grenadian examples really are distinct from those which Duméril and Bibron described; and which came from Colombia. It is said to occur in Venezuela, and more recently it has been recorded from Trinidad by Mole and Urich (Journ. Trinidad field. nat. club, 1894, 2, p. 82). Specimens collected recently by Dr. Thaxter enable me to compare the species from Grenada and Trinidad.

Type:- No. 7,793, M. C. Z., an adult, St. George's, Grenada, G. M. Allen, collector.

Upper head shields consisting of a pentagonal internasal, a pair of prefrontals forming a short suture, a frontal considerably longer than broad, heptagonal, a pair of large parietals, a narrow quadrangular interparietal of equal length, and four supraoculars. Nasal more than twice as broad as high; loreal about one half the size of nasal; the longest infraorbital in contact with the third, fourth, and fifth supralabials; eight temporals; six upper labials, third and last largest, and of almost equal size; six lower labials; mental equal in size to one of the first pair of labials next to it; first pair of chin shields posterior to the large postmental, forming a wide suture; collar shields enlarged, eight in number. Twenty-eight scales around middle of body, and forty from occiput to base of tail; ventrals somewhat longer than broad, forming eight longitudinal series, and twenty-six transverse series from the two enlarged pectorals to the preanals; these are four in number, and the median posterior is the smallest. Tail long, rounded at the end; covered with imbricate elongate hexagonal scales, the upper smooth, the lower carinated. Reddish brown above, lighter beneath. Varia- 
tions:- Some specimens show traces of a light, dark-bordered lateral line on the body, in several this is fairly distinct on the tail. There is considerable variation in the supralabials; in one, the fifth and sixth are of about equal size and slightly larger than the third. This specimen has but five infralabials.

This species may be distinguished from S. cuvieri (Dum. \& Bibr.) by the possession of any one or more of the following characters (they may not all be unvarying or equally diagnostic in the same individual):- The frontal is usually distinctly longer than broad; the last supralabial is not the largest; there are more than four infralabials; the dark-bordered light line is almost never present on the body, but it may be evident on the tail. Duméril and Bibron (Erpét. gén., 1839, 5, p. 455) speak of seven upper labials of which the fifth is a scalene triangle; in S. alleni the fifth is pentagonal. Boulenger mentions but six upper labials; it is somewhat difficult to determine just where labials end and contour scales begin. Again, Duméril and Bibron characterize the Colombian specimens as having twenty-six rows of scales, and six rows of ventrals. Boulenger, Garman, and I all agree on twenty-eight rows about the middle of the body.

Except Trinidad, Grenada is the only island in the West Indies where this genus is found.

Scolecosaurus trinitatis, sp. nov.

Type:- No. 8,947, M. C. Z., an adult, Caparo, Trinidad, A. B. Carr, collector. Found under fallen cocao pods. Eight paratypes bear the same data.

The collection given recently by Professor Thaxter contains nine of these lizards from Trinidad and ten from Grenada. For the first time it is possible to compare a series from these islands. They represent a new species closely related, both seeming to differ in the same manner from the Columbian S. cuvieri. In describing the previous species I have pointed out these different characters. In Grenadian specimens the prefrontals, form a short suture, this is the condition which the published records also indicate for the mainland specimens. The specimens from Trinidad, on the other hand, seem to have the prefrontals invariably well separated, and not forming a suture. The series of nine all show this condition. Thus, even if it should not prove to be absolutely constant it is at least the characteristic condition and as the opposite seems equally constant in the Grenadian specimens, the Trinidad form is entitled to specific rank. 
Gymnophthalmus pleii Bocoorr.

Bocodrt, Miss. sci. Mex. Reptil., 1881, p. 473, pl. 22, H, fig. 3. Boulenger, Cat. lizards Brit. mus. 19, 1885,2, p. 429.

Garman (Bull. Essex inst., 1887, 19, p. 12) records the capture of this species at Martinique, the type locality, and at St. Lucia, whence G. luetkenii is supposed to have come. He says, "Bocourt gives St. Lucia as the locality for G. lütkeni; we failed to secure a specimen in all our collecting."

Boulenger (Proc. Zool. soc. London, 1891, p. 353) writes: "Like Mr. Garman I find the St. Lucia specimens to be referable to G. pleii, described by Bocourt as from Martinique, and not to G. luetkenii, of the same author, from St. Lucia."

It is thus evident that this species, G. pleii, is apparently the only one found on both islands, in which case the locality for the type of the other species was undoubtedly incorrect.

\section{Amphisbaena punctata BeLx.}

Belu, Zool. journ., 1828, 3, p. 236. Boulenger, Cat. lizards Brit. mus., 1885, 2, p. 450, pl. 23, fig. 3.

This little-known species is recorded only from Cuba. I succeeded in procuring two specimens, one at San Diego de los Baños, and the other near Herradura. Both were turned out in ploughing. This species grows to be larger and is much more light colored in life than the following. The few specimens of this genus which I saw in the Museums in Havana all belonged to this species. It may be confined to the region from the Province of Matanzas, west to Pinar del Rio.

\section{Amphisbaena cubana Peters.}

Peters, Monatsb. Akad. wiss. Berlin, 1878, p. 780, pl. -, fig. 4. Boulenger, Cat. lizards Brit. mus., 1885,2, p. 446.

Stejneger has discussed the question as to the distinctness of this species under the heading of A. caeca in Porto Rico (Rept. U. S. nat. mus. for 1902, 1904, p. 676). There can be but little doubt of its distinctness. It is confined to Cuba.

Since the above was written I have been able to examine twenty-six specimens obtained by following plows in the cane fields of the Soledad estate, near Cienfuegos. All of these have the ocular fused with the second labial, so that there can be no doubt as to the stability of this character. Boulenger was inclined to regard this condition as anomalous and to unite this species with $A$. caeca. There is, however, no reason whatever for doing this. In the region about Cienfuegos, where these specimens were found I did not find a single 
example of $A$. punctata. The people, however, led me to believe that another "Culebrita ciega" occurred which was not Typhlops lumbricalis. The latter is often called "vibora."

\section{Amphisbaena innocens WeINLAND.}

Weinland, Abh. Senck. naturf. gesellsch., 1862, 4, p. 137, pl, 5, fig. 2.

Weinland states that he captured three specimens near Jeremie, Haiti; and at the end of the description says that one was sent to the Berlin Museum,whether before or after the description was written does not appear. At any rate it is quite certain that M. C.Z., No. 3,624 and 3,625 are the other two specimens of the three captured, since they bear the label "Jeremie, Haiti,-collected by Dr. D. F. Weinland." They were received when the Weinland collection was purchased during Louis Agassiz's administration.

Regarding the distinctness of this species from A. caeca I can only say that both specimens have two instead of three scales behind the unpaired postmental, and that their number of body rings is low, 212 and 213 . Since these characters fall within the range of what Stejneger (Rept. U. S. nat. mus. for 1902, 1904, p. 677) has suggested is probably diagnostic for the species, there can be no doubt but that there is now sufficient evidence as to the stability of these characters to make it quite certain that this is a valid species.

In the Zoological record for 1865 (p. 149) Günther, after reviewing Gray's Catalogue of the Amphisbaenidae; which appeared that year, makes the note that "we understand that the $A$. innocens (Weinland) has been previously described." Gray (Cat. shield rept., 1872, 2, p. 3\%), although admitting this species to his list, repeats that it is "understood to be previously described." It is difficult to understand how this apparently erroneous idea can have arisen, unless some obscure publication has escaped all recent herpetologists.

Since all the above was written Mann's collection has brought a typical example from Manneville, Haiti. This shows all the peculiar characters of the types.

\section{Amphisbaena manni, sp. nov.}

Type:- No. 8,645, M. C. Z., Cape Haitien, Haiti, W. M. Mann, collector. Three paratypes from the same locality.

This is the Haitian representative of A. caeca of Porto Rico. It resembles this species in having a similar arrangement of head and chin shields. The series shows that this condition is quite unstable but probably equally so in $A$. caeca. The number of dorsal and ventral segments of a single annulus of scutes is the 
same in both species being 16 above and 18 below. The species, however, really differ widely, in that $A$. manni has eight femoral pores and $A$. caeca only four. The new Hxitian form has a greater number of rings on the tail, 24, against an average of 17. The number of body rings is high, 227. This is exceeded by an occasional specimen from Porto Rico.

The paratypes show that the number of femoral pores is regularly high. Two having eight and the other (abnormal in other respects) but seven. The tail rings number twenty-three to twenty-five except in this abnormal example in which the tail is much reduced there being only seven rings. It shows no sign of injury and is probably simply malformed. It is hard to imagine how an Amphisbaena could have had its tail accidentally removed.

The apparent anomaly in distribution presented by the fact that there were two species of Amphisbaena on Cuba and Porto Rico and but one on Haiti is now cleared up. Before Mr. Mann left for Haiti I suggested that diligent search would reveal a new. Amphisbaena, and it is fitting that it should bear his name.

\section{Amphisbaena caeca Cuvier.}

Cuvier, Reg. anim., 1829, 2, p. 73. Stejneger, Rept. U. S. nat. mus. for 1902, 1904, p. 676, fig. 129132.

The habits, habitat, and relationships of this species have been fully discussed by Stejneger. The species is confined to Porto Rico.

\section{Amphisbaena bakeri STEJNEGER.}

STEJNEGER, Rept. U. S. nat. mus. for 1902, 1904, p. 681, fig. 183.

A well-defined species, confined to Porto Rico where its distribution seems to be very local. The only specimens known which bear a definite locality record are from Lares. This is in sharp contradistinction to the distribution of A. caeca, which occurs widespread over the entire island.

Amphisbaena fenestrata Cope.

Cope, Proc. Acad. nat. sci. Phila., 1861, p. 76. Boulenger, Cat. lizards Brit. mus., 1885, 2, p. 449.

This distinct species is confined to the Virgin Islands. The types came from St. Thomas and St. Croix. It has since been recorded from St. John, which with St. Thomas formed the type locality of the synonymous species, $A$. antillensis Reinhardt \& Lütken. 
Mabuya spilonota WIEGMANN.

Wiegmann, Arch. f. naturg., 1837, p. 135.

This Iamaican species should bear this name, as has been shown by Stejneger, who agrees with Garman as to its validity. (Stejneger, Rept. U. S. nat. mus. for 1902, 1904, p. 608). This is the species of which I (Bull. M. C. Z., 1910, 52, p. 299) gave a short account regarding its habits, abundance, and distribution, unfortunately using the name $M$. sloanii, inadvertently following Garman instead of Stejneger, although the latter is obviously correct in the application of these names.

Mabuya sloanii (DAUDIN).

Daudin, Hist. nat. rept., 1803, 4, p. 287, pl. 55, fig. 2. STEJNEger, Rept. U.S nat. mus. for 1902, 1904, p. 608 , fig. $56-58$.

Stejneger (loc. cit.) has given excellent reasons for using this name for the Porto Rican Mabuya, and also for considering this form distinet from that upon Jamaica. This species, in common with its other generic relatives, is one of the very first species to succumb to the ravages of the mongoose. In Porto Rico it was so rare that Stejneger and the other naturalists with him did not find a single example. This has been the experience of many other collectors upon other islands. A regrettable fact since large series of specimens are particularly desirable to settle definitely the many questions regarding variation within the species of these variable forms, and to determine how distinct the various insular races really are.

The range of Mabuya sloanii comprises the islands of Vieques, Porto Rico, Mona, St. Thomas, St. John, Just van Dyke, St. Croix, and besides this the limited material indicates that Haitian specimens should be referred to the same species.

Mabuya mabouia Dumértl et Bibron.

Dumḱril et Bibron, Erpét. gén., 1839, 5, p. 646 . Garman, Bull. Essex inst., 1887, 19, p. 52.

The specimens in the Museum are from Martinique. The describers state that they have received it also from Guadeloupe. It is not probable, however, that the scincs upon these two islands should be alike, and those upon Dominica different, when the latter island lies exactly between them.

Mabuya lanceolata Cope.

Cope, Proc. Acad. nat. sci. Phila., 1862, p. 187.

This species was based upon Barbadian specimens collected by Theodore Gill. I have seen no specimens and cannot comment upon the validity of the species. 


\section{Mabuya dominicana GARMAN.}

Garman, Bull. Essex inst., 1887, 19, p. 52.

"Mr. Garman describes specimens from Dominica as a distinct species, said to be distinguished from $M$. agitis by having the supranasals separate from each other, and possessing from 68 to 72 scales in a series between the chin and vent. His $M$. agilis is stated to have the supranasals in contact with each other and only 54 or 56 scales between chin and vent.

The eight adult specimens from Dominica before me vary in both these respects; some have the supranasals in contact, others not. Between chin and vent there are 60 scales in two, 62 in one, 63 in two, and 64, 65, and 67 severally in single specimens. Therefore the characters on which Mr. Garman based his distinction are in these specimens so obviously variable that no herpetologist will place any reliance upon them.

But to prove the variability of these characters in this species beyond further dispute I took from a gravid female six embryos, all fully developed and about half the length of the mother. The mother had the supranasals in contact with each other and 62 scales between chin and vent. Of her progeny two had the supranasals as in the mother, in three they were separate from each other, whilst one might be assigned to either category. The scales on the abdomen are in 57 rows in two of these embryos and in $61,62,65$, and 66 rows severally in their brothers.

Specific distinctions in these days are held to be, and often may be, matters of individual opinion and, as a rule, I abstain from entering into any discussion about them; but they sometimes have a direct bearing upon wider and more important questions. In this case any one studying the distribution of reptiles over the West Indies would, by relying on statements such as are propounded by Mr. Garman in his recent publications on West-Indian reptiles, be misled into the view of a more complete isolation and specialization of the faunas of the various islands than obtains in reality. He states in fact in this instance that the widely distributed Mabuia agilis has been sufficiently differentiated in Dominica to form a distinct species or whatever it may be called, whilst the examination of even a small number of examples disproves this statement. Distinctive characters, no matter how trivial they appear to be, become important enough to the systematic zoologist if they be found constant in a number of specimens and correlated to some other point of the life of an animal; but unless this has been ascertained to be the fact, their indiscriminate use impedes rather than advances zoology." 
Günther's remarks, which I have quoted at length, apply far better to his own attitude than to that of Garman; he has not shown at all that the range of variation for $M$. dominica, which he had increased, touches the range for that of $M$. agitis; while the average condition seen in the two categories of individuals show how distinct they are. Invidious remarks regarding the sense of specific discrimination are always dangerous.

The types are M. C. Z., No. 6,049.

Mabuya luciae Garman.

Garman, Bull. Essex inst., 1887, 19, p. 51. Boulenger, Proc. Zool. soc. London, 1891, p. 353.

While considering this species as a variety of $M$. agitis, Boulenger admits its subspecific rank. For the sake of consistency it is here considered a full species; there being, however, obviously no question as to its origin from this mainland species. It occurs upon St. Lucia. The types are M. C. Z., No. 6,046.

Mabuya aenea Gray.

Gray, Griffiths Cuvier's Animal kingdom, 1831, 9, Syn. reptil., p. 70. Garman, Bull. Essex inst., 1887,19, p. 53.

Garman considers specimens from St. Vincent, Grenada, and Trinidad distinct from $M$. aurata Schneider, from southern Central America to Brazil. Boulenger (Proc. Zool. soc. London, 1891, p. 355) considers the Antillean specimens referable to the latter species. If, when it becomes possible to study large series, the characters which Garman points out are found to be constant, then each of the two groups of individuals will be obviously entitled to hold specific rank.

\section{Typhlops lumbricalis LINNÉ.}

LinnÉ, Syst. nat. ed. 10, 1758, 1, p. 228 . STEJNEGER, Rept. U. S. nat. mus. for 1902, 1904, p. 684.

This species extends from the region of the Guianas to both the Lesser and Greater Antilles. It has long been known from many islands, among them Dominica, St. Kitts, Antigua, the Virgin Islands, Guadeloupe, Martinique, Mona, Porto Rico, Haiti, Jamaica, Cuba, and some of the Bahamas. In the latter group it was first recorded by Cope (Proc. U. S. nat. mus., 1887, 10, p. 439) from Great Abaco. In 1904 I found it again on the same island (Bull. M. C. Z., 1904, 46, p. 59). Curiously enough it was not found on either New Providence or Andros Island until Rosén collected specimens at both localities (Rosén, Lunds univ. arsskrift, 1911, 7, no. 5, p. 37). In Cuba and Jamaica its distribution is very wide, and I have found it at practically every station visited. 
Typhlops pusillus, sp. nov.

Type:- No. 8,719, M. C. Z., Cape Haitien, Haiti, W. M. Mann, collector. Four paratypes, two from Grand Riviere, one from Cape Haitien and one from Ennery, Haiti.

Similar to T. lumbricalis in color and number of rows of scales, which are twenty in number, but widely different from this and the other West Indian species in details of cephalic squamation.

Snout depressed and somewhat projecting; nostrils below lateral horizontal edge; rostral a little less than two sevenths the width of the head, not extending backward to the line of the eyes; details of head shields as shown in drawings. Scales in twenty rows; about 370 scales on midventral line from chin to vent, and nineteen under tail, which ends in a spine. Color
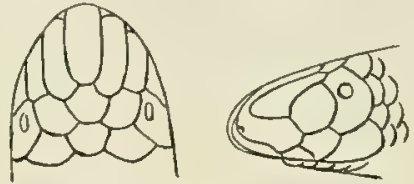

Top and side view of head of type enlarged six times.

brown; edges of scales darker than their centres; ventral surfaces cream color. Size of type, about five inches.

Typhlops tenuis SaLvin.

Salvin, Proc. Zool. soc. London, 1860, p. 454. Boulenger, Cat. snakes Brit. mus., 1893, 1, p. 28. Rosén, Lunds univ. arsskrift, 1911, 7, no. 5, p. 37

Rosén found a single specimen which he identified with this species at Mastic Point, Andros Island. It had, however, twenty-two rows of scales about the body instead of eighteen; and as this character is not variable among many Typhlopidae, $T$. tenuis among them, there is ground for reasonable doubt as to the correct identification of the species. Rosén does not mention that he had other specimens for comparison. The species is one which ranges through southern Mexico and Guatemala.

\section{Typhlops rostellatus STEJNEGER.}

StejNeger, Rept. U. S. nat. mus. for 1902, 1904, p. 686, figs. 146-147.

A species peculiar to Porto Rico, which upon that island takes the place of its close relation, T. platycephalus Duméril \& Bibron from Martinique, and $T$. dominicana Stejneger from Dominica. There yet remain many islands from which representatives of this group of species have not yet been described, but upon which they undoubtedly exist. 
Typhlops platycephalus DumérIL ET BiBroN.

Duméril et Bibron, Erpét. gén., 1844, 6, p. 293.

A species sent from Martinique by Plée to the Paris museum. It is confined to the island, and is very rare in collections; of its abundance on the island nothing is known.

\section{Typhlops dominicana Stejneger.}

SteJNEGER, Rept. U. S. nat. mus. for 1902, 1904, p. 687.

Stejneger has shown that Boulenger's description (Cat. snakes Brit. mus., 1893,1, p. 30) of $T$. platycephalus Duméril \& Bibron, based on specimens from Dominica, differs in important characters from the original description based on specimens from Martinique. He then proposes for the species apparently confined to Dominica, of which in 1893 there were four specimens in the British museum, the name Typhlops dominicana.

Leptotyphlops albifrons (WAGLER).

Wagler, Spix's Serp. Braz., 1824, p. 68, pl. 25, fig. 3. Boulenger, Cat. snakes Brit. mus., 1893, 1, p. 63.

This very widely distributed species, besides being recorded as distributed on the Tropical American mainland, has been recorded in the Antilles from Watlings Island, Grenada, and Antigua. It doubtless ranges widely through the Lesser Antillean chain. Recently Mr. Nelson has brought back a series of eight specimens from Swan Islands. He reports it common there and found in the leaf mould of the forest, it is often seen in broad day light crawling about in paths and clearings.

Leptotyphlops bilineata (Schlegel).

Schleqer, Abbild. Amphib., 1844, p. 36, pl. 32, fig. 5-6. Bodlenger, Cat. snakes Brit. mus.,1893, 1, p. 70 .

Recorded originally by Duméril and Bibron (Erpét. gén., 1844, 6, pp. 331) from Martinique and Guadeloupe. There was also a specimen from Barbados in the British museum. The snake is apparently rare, and is seldom found by collectors.

Epicrates subflavus Stejneger.

Stejneger, Proc. U. S. nat. mus., 1901, 23, p. 469-470.

The Jamaican yellow boa was only separated in 1901, after very many years of confusion with the Porto Rican species, $E$. inornatus. It has been almost exterminated by the ravages of the mongoose (Herpestes birmanicus 
(Thomas)), and while excessively rare on Jamaica, is said to still be quite abundant on Goat Island, not far from Old Harbor. It probably still occurs along with the Iguana (Cyclura collei Gray) in the Heathshire Hills, in the southern part of the island.

\section{Epicrates striatus (FISCHER).}

Fischer, Abhandl. Naturh. ver. Hamburg, 1856, 3, p. 102, pl. 2, fig. 2. Bodlenger, Cat. snakes Brit. mus., 1893, 1, p. 96-97. Stejnegre, The Bahama Islands, 1905, p. 336.

This species occurs on San Domingo, New Providence, and Andros. In 1904 I mentioned Bahaman specimens under the name of E. strigilatus Cope; since that time I have been able to compare much additional material, and now subscribe to the views of Boulenger, Stejneger, and, more recently, Rosén, that the San Domingan and Bahaman individuals are conspecific (Barbour, Amer. nat., 1906, 40, p. 230).

Epicrates monensis ZENNECK.

ZENNECK, Zeit. wiss. zool., 1898, 64, p. 64, pl. 3, fig. 58-62. STEJNEGER, Rept. U. S. nat. mus., for 1902, 1904, p. 692.

This boa, confined to Mona Island is one of a number of small species whose status and relationships are as yet more or less enigmatical.

Epicrates chrysogaster COPE.

Cope, Proc. Amer. philos. soc., 1871, 11, p. 557. STEJneger, The Bahama Islands, 1905, p. 335.

Stejneger has pointed out that this species should be kept separate from its ally, $E$. fordii (Günther), from Haiti, on account of having forty-three rows of scales, and fifty-four dorsal spots, whereas $E$. fordii has $33-37$ scale rows, and 69-78 dorsal spots. It is confined to Turk's Island, and is also very closely related to the preceding.

\section{Epicrates fordii (GüNTHER).}

Günther, Proc. Zool. soc. London, 1861, p. 142, pl. 23. Boulenger, Cat. snakes Brit. mus., 1893, 1, p. 98 .

Boulenger unites this species with the preceding, but probably this form from Haiti is not really the same as the Turk's Island species. More material is badly needed of all these boas.

Epicrates inornatus (REINHARDT).

Reinhard, Danske vid. selsk. Afhandl., 1843, 10, p. 253. SteJneger, Rept. U. S. nat. mus. for 1902, 1904, p. 688.

This boa, closely related to the Jamaican yellow boa, and but recently recognized as distinct, is confined to Porto Rico. It has grown very rare, and recent collectors have had great difficulty in procuring specimens. 
Epicrates gracilis (FISCHER).

Frscher, Jahrb. Ḣamburg, wiss. anst., 1888, 6, p. 35, pl. 3, fig. 8. Boulenger, Cat. snąes Brit. mus., 1893,1, p. 98.

This boa, which is said to be "blackish gray, somewhat lighter on the belly," and having "six longitudinal series of small black spots," has evidently a type of coloration very different from other species in the genus. Boulenger suggests that it is "closely allied" to $E$. fordii; but to judge from the description, they seem to be very unlike. This is evidently a rare species, since up to 1893 no specimens had found their way to the British museum. It was described from San Domingo, yet none of the collections from that island in the Museum contain specimens.

Epicrates angulifer BIBRON.

Bibron, Sagra's Hist. Cuba. Rept., 1843, p. 215, pl. 25. Botlenger, Cat. snakes Brit. mus., 1893, 1, p. 96 .

The "majase," or "maja," as the Cuban boa is called locally, is still common in many regions of the island. Miller, quoting Palmer's field notes (Proc. U. S. nat. mus., 1904, 27, p. 346) says, in speaking of the great bat caves about Baracoa and Guanajay, "The people of the neighborhood assured me that the majas (the Cuban boa, Epicrates angulifer) coil themselves among these roots [of the trees near the mouth of the cave], and grab at the bats as they fly out. I was told that a snake frequently secures a bat in this manner." . I have also heard this tale.

This is far the largest member of the genus. It grows commonly to be twelve feet long and to be as large in circumference as any boa, or as a Python of far greater length. Gundlach records individuals of five and seven yards length. Such specimens would be excessively rare now owing to the persecution which the species has undergone with the increasing population and cultivation of the island. I got two living specimens near Havana, which were singularly intractable; and the species is characterized by its very bad temper. I have seen other specimens elsewhere. It is wide spread and common.

Boa hortulana LiNNÉ.

Linné, Syst. nat. ed. 10, 1758, 1, p. 215 . Boulenger, Cat. snakes Brit. mus., 1893, 1, p. 101-102.

Dr. Allen brought back three examples of this arboreal species, all of them taken near St. George's. Garman (Proc. Amer. philos. soc., 1887, 24, p. 279) records specimens from Trinidad, Grenada, St. Vincent, and the Grenadines. 
He shows how excessively these vary in color, his three examples from Grenada differing much from one another. The same is true of Allen's specimens. There is, then, no evidence, either in squamation, or coloration, of the formation of a local race of this species upon Grenada. Boulenger (Proc. Zool. soc. London, 1891, p. 355-356) records the finding of specimens on St. Vincent and Becquia. No mention, however, was made of these specimens in the Catalogue of snakes in the British museum, the last volume of which, with addenda, did not appear until 1896.

= Boa grenadensis, sp. nov.

Type:- No. 7,991, M. C. Z., St. George's, Grenada, August 29, 1910, G. M. Allen, collector. Another example, taken August 20, No. 7,990, M. C. Z., is a cotype.

Boulenger (Cat. snakes Brit. mus., 1893, 1, p. 100) records four specimens of what he calls Corallus cookii var. C. from Grenada. These alone, among all his series, are characterized by being yellowish brown above, uniform or with mere traces of dark markings; belly yellow, without spots. Allen brought back two examples, both from St. George's, Grenada; and as these agree in coloration with what Boulenger has described, there can hardly be reasonable doubt but that a local race, with characteristic color, has become differentiated upon this island. The scale counts for Boulenger's specimens follow:-

$$
41 \frac{268}{101}, 43_{109}^{270}, 41_{105}^{264}, 43_{105}^{2.53}
$$

The type, M. C. Z., No. 7,991, counts $45 \frac{270}{114}$, while the other example has 43 scale rows, but was damaged so that the other counts can not be made. The range for these six is, then, $41-45 \frac{253-270}{101-114}$. This does not vary far from a similar series from other localities. Garman did not find this snake on Grenada. According to Allen, it is known locally as "sarpint" in contradistinction to "snake," this latter name being confined to the Racer. For the use of Boa instead of Corallus consult Stejneger, Proc. U. S. nat. mus., 1902, 24, p. 184.

\section{Tropidophis melanura SCHLEGEL.}

Schleger, Essai phys. serp., 1837, 2, p. 399. Bodlenger, Cat. snakes Brit. mus., 1893, 1, p. 111.

Stejneger (The Bahama Islands, 1905, p. 336) states that Tropidophis takes precedence over Ungualia, since the former was based on Schlegel's Boa melanura by Bibron in 1840, and thus antedates Gray's Ungualia by two years.

This species is not uncommon, and I found it and heard of its regular occurrence in just one lurking place. A number of specimens were found in various localities on Soledad estate, near Cienfuegos, Cuba, always hidden in the rolled 
up 'yaguas,' expanded bases of the leaves of royal and cocoanut palms. Where there is a grove of these trees in an orchard or some other wooded locality, the curled up fallen leaves will often be found to contain this snake. I never, however, came across a specimen where the leaves fell so as to be exposed to the full force of the sun. The species is strictly nocturnal and evidently does not prowl about in the open, unwooded country.

The Museum had several specimens from "Cuba" before the receipt of the series from Soledad in 1912. In 1913 I had a fine series of well-preserved examples given me by Mr. C. T. Ramdsen who took them in the region about Guantanamo. In addition to the bluish and reddish phases of coloration two of these are clear unmarked light buff. This species is evidently the most variable in coloration of any in the genus.

Tropidophis pardalis (GUNDLACH).

Gunddach, Arehiv. naturg, 1840,' 1, p. 359. Boulenger, Cat. snakes Brit. mus., 1893, 1, p. 113. STEJNEGER, the Bahama Islands, 1905, p. 336.

The Bahaman "thunder snake" has been referred to T. maculata by Cope, but incorrectly, as I have identified specimens with this species (Bull. M. C. Z., 1904, 46, p. 59; Amer. nat., 1906, 40, p. 230) from New Providence; and Stejneger has since agreed to this identification.

The species has been found on Cuba, New Providence, Andros, and Eleuthera Islands.

A specimen No. 6,114, M. C. Z. from Cuba, is labeled in Garman's hand as Ungalia curta, and probably served him as the type of that species. He gave Cuba as the locality, and this is the only Cuban specimen having such a label.

The species is a synonym of the above.

I did not meet with this species during my collecting trips in Cuba.

Tropidophis maculata (BIBRoN).

Birron, Sagra's Hist. Cuba. Rept., 1843, p. 212, pl. 24. Boulenger, Cat. snakes Brit. mus., 1893, 1, p. 112.

This species may possibly be a composite one. Cope held that Haitian individuals were distinct from others, and proposed for them the name of $T$. haetiana. They have not been shown to be really different. Nevertheless, at present only a few specimens have been recorded from the islands where the species occurs, and large series will unfortunately be increasingly difficult to obtain. In Cuba the species is far from common, while on Jamaica and Haiti the mongoose is already omnipresent. The snake is also recorded from the 
island of Navassa, where the mongoose has probably not been introduced. In Jamaica I found it extremely rare, and got only one specimen, the mongoose being undoubtedly responsible for its scarcity. From Haiti the Museum has but two specimens. From Cuba there are three, two from Havana and one from Soledad, near Cienfuegos. While the specimens from each of these localities show certain peculiar characteristics in coloration, their squamation does not vary definitely. The series from Jamaica, Haiti, and Cuba seems to belong to the same species.

Mr. Mann's recent collection contains three specimens from Cape Haitien and one from Diquini, Haiti. In only one is the interparietal present as Cope supposed is always the case with Haitian examples. In three examples the scale rows number 27 and in one 25 , in none 29. This is the number also declared a character of $T$. haetiana. Nevertheless much more material is needed to show that the place modes do not differ with series from the several islands. I may be quite wrong and inconsistent in not allowing $T$. haetiana to stand separately but there is not much proof of its distinctness.

Tropidophis semicincta (Gundlach \& Peters).

Gondlach \& Peters, Monatsb. Akad. wiss. Berlin, 1864, p. 388. Bodlenger, Cat. snakes Brit. mus., 1893,1, p. 113.

Apparently a very rare species, confined to Cuba. Unfortunately I was unable to obtain a single specimen of this species. There is a fine example in the Gundlach collection in the Instituto de Segunda Ensañanza at Havana, and two in the U. S. national museum at Washington.

Tropidophis conjuncta Fischer.

Frscher, Jahresb. Hamb. wiss. anst., 1888, 5, p. 31, pl. 3, fig. 5. Boulenger, Cat. snakes Brit. mus., 1893,1, p. 113.

Another obscure and little-known species, confined to San Domingo.

Tropidophis cana (CoPE).

Cope, Proc. Acad. nat. sci. Phila., 1868, p. 129. Bodlenger, Cat. snakes Brit. mus., 1893, 1, p. 114.

A very distinct species confined to the island of Inagua in the southern Bahamas.

Constrictor orophias (Linnt).

Linnt, Syst. nat. ed. 10, 1758, 1, p. 215. Bodlenger, Cat. snakes Brit. mus., 1893, 1, p. 118.

Stejneger, in showing that for these large tree snakes the generic name Constrictor should be used instead of the long-established Boa, remarked at the 
same time that Linné's Boa orophias was the same species as that named Constrictor divinitoquus by Laurenti (1768). The latter name, variously spelled, has usually been used for the Lesser Antillean Constrictor. Boulenger had, in 1893, specimens in the British museum from St. Lucia, Dominica, and Trinidad. The Philadelphia Zoological garden has had one said to have been taken upon St. Kitts.

Andersson (Bihang K. Svensk. vet.-akad. Handl., 1899, 24, afd. 4, no. 6, p. 33) also shows that the type of Linné's Boa orophias is the same as the later named diviniloqua.

Tretanorhinus variabilis DUMÉRIL ET BiBRoN.

Duméril et Bibron, Erpét. gén., 1854, 7, p. 349, pl. 80, fig. 4. Bodlenger, Cat. snakes Brit. mus., 1893,1, p. 282

This species is the Cuban representative of a small genus, the other two species of which occur in Central America. It is a strictly aquatic snake which never leaves the water. It is not uncommon about ponds and rivers, both rushing and sluggish. It does not often sun itself, but remains for the most part hidden in dense aquatic vegetation or among and under loose stones. The natives all say that it is nocturnal and that they often meet it in rivers swimming about when they are fording the streams by night. It is a difficult species to find, but is undoubtedly rather common and widespread. I have specimens from near Cienfuegos and San Diego de los Baños while I saw others near Pinar del Rio city, and near Herradura. It is called "catibo," and I often heard of it by this name in other parts of the island. In $1913 \mathrm{I}$ caught it in the Rio Tana, Ingenio "San Ramon," not far from Manzanillo.

\section{Drymobius boddaertii (SENTZEN).}

Sentzen, Meyer's Zool. arch., 1796, 2, p. 59. Boulenger, Cat. snakes Brit. mus., 1894, 2, p. 11.

Recorded by Boulenger from St. Vincent. A species common and widespread on the mainland (Proc. Zool. soc. London, 1891, p. 355). In the Catalogue (loc. cit.) Boulenger mentions a specimen from Grenada sent by this Museum to the British museum. Garman collected examples only on St. Vincent, to judge by his paper on West Indian snakes (Proc. Amer. philos. soc., 1887, 24, p. 284). I can find no Grenadian examples in the Museum now, and Garman would not have been likely to have sent the only one from this locality to London. Neither Dr. Allen nor Mr. Brues, in their recent exploration of Grenada, saw or heard of this species, so that in all probability the British museum's snake came from Kingston, St. Vincent, apparently the only island where Garman found the 
species, and perhaps the only island where it occurs. It would certainly be natural to expect this species upon Grenada, and perhaps its absence there may be laid to the account of the mongoose, as may also be the case with other species which might be expected upon this island.

Herpetodryas carinatus (LINNE).

Linne, Syst. nat., ed. 10, 1758, 1, p. 223. Boulenger, Cat. snakes Brit. mus., 1894, 2, p. 73.

This mainland species has been recorded from the island of Guadeloupe, and Boulenger says that he has compared this specimen from Guadeloupe in the British museum with mainland examples, and can find no difference between them. It does not appear to be recorded from others of the Antilles, and may possibly have been brought to Guadeloupe as a rat exterminator. It would be expected to occur upon other islands if its distribution had not been by artificial agency. Of course it is not improbable that the locality may not be correct.

\section{Herpetodryas vincenti Botlenger.}

Boulenger, Proc. Zool. soc. London, 1891, p. 355.

This species, which was originally described as a variety, differs in having a greater number of ventrals and subcaudals, and in being more slender than the mainland form. The types, in the British museum, came from St. Vincent. The two specimens in the Museum from this island also show these characters.

Uromacer catesbyi (SCHLEGEL).

SChlegel, Essai phys. Serp., 1837, 2, p. 226. Bodlenger, Cat. snakes Brit. mus, 1894, 2, p. 115.

A rare member of this peculiar genus, which is wholly confined to Haiti. Its habit, which is so strikingly like that of Dryiophis in the Old World and Oxybelis in the New, is a marvellous adaptation to arboreal life, since this snake is hardly more related to either of these genera than they are to each other. The Museum has several specimens, including three which Mr. W. M. Mann caught at Momance, Haiti.

Uromacer frenatus (GÜNTHER).

GÜNther, Ann. mag. nat. hist., 1865, ser. 3, 5, p. 116. Bodlenger, Cat. snakes Brit. mus., 1894, 2, p. 116.

Another species confined to Haiti. I had some difficulty in locating the types of Garman's Uromacer inornatus, which Boulenger rightly placed in the synonymy of this species. Finally, however, I found four examples which agreed exactly with Garman's description as to scale counts, so that there can 
be no possible question as to the fact that these are the actual types. They had been relabeled by Garman as Uromacer oxyrhyncus, but they really belong with this distinct species. The specimens are No. 3,345, M. C. Z., two examples from Haiti, and No. 3,610 M. Z. C., two examples from Jeremie. Garman in his description, undoubtedly by a lapsus calami, credited all four specimens to Jeremie, Haiti (Proc. Amer. philos. soc., 1887, 24, p. 284). In Mr. Mann's collection there are three from Diquini, Haiti and one from Manneville.

Uromacer oxyrhynchus DUMÉRIL ET BiBRon.

Duméril et Bibron, Erpét. gén., 1854, 7, p. 722, pl. 83, fig. 1. Boulenger, Cat. snakes Brit. mus. 1894,2, p. 116 .

The third and last member of this genus is, of course, also from Haiti only. The specimens in the Museum are from Santiago de la Vega, collected by Mr. A. H. Verrill; Samana, San Domingo, collected by Mr. M. A. Frazar, and Diquini from Mr. W. M. Mann. Other examples are simply labeled Haiti. There is no evidence from the material preserved here to show that the species of Uromacer are confined to particular ranges within the area of the island.

\section{Hypsirhynchus ferox GüNTHER}

GüNTher, Cat. snakes Brit. mus., 1858, p. 48. Boulenger, Cat. snakes Brit. mus., 1894, 2, p. 117, pl. 6, fig. 1 .

This species was originally described as coming from Barbados, and became established in the literature as a Barbadian anomaly. Thus Wallace mentions it in the Geographical distribution of animals (2, p. 72). Boulenger, however, has shown that the type was purchased for the British museum from Hugh Cuming, and that all his collection contains only species characteristic of Haiti or San Domingo. The genus is, then, a monotypie one, confined to the island. Hypsirhynchus scalaris Cope, the type of which is No. 1,517, M. C. Z. was described when $H$. ferox was supposed to come from Barbados; and the distance of that island from Haiti may have suggested the supposed distinctness of the species. Cope's type appears to be sightly abnormal in that it lacks a loreal. This would not seem sufficient to establish a species when only one specimen is known which is characterized in this way.

Mr. Mann's collection contains an example from Momance, and another from Manneville. Both perfectly typical. 


\section{Alsophis angulifer BrBRon.}

Bibron, Hist. Cuba. Rept., p. 222, pl. 27. Bodlenger, Cat. snakes Brit. mus., 1894, 2, p. 120, (part).

A very common Cuban species. No. 2,195, M. C. Z., came from the Paris museum in an old exchange and is marked as a type by A. Aug. Duméril. Boulenger has considered the specimens from the Bahamas and the Cayman Islands all identical with the Cuban examples. They are separated here.

This species has been met with on my Cuban trips at every locality visited and specimens have been preserved from Pinar del Rio, Herradura, San Diego de los Baños, Havana, Manzanillo, and Cienfuegos. It is said to reach a length of over two meters but none was seen larger than four feet.

\section{Alsophis caymanus Garman.}

Garman, Proc. Amer. philos. soc., 1887, 24, p. 276.

This species replaces the Cuban $A$. angulifer upon the island of Grand Cayman. The type is No. 6,020, M. C. Z. It is of doubtful validity.

\section{Alsophis fuscicauda Garman.}

Garman, Bull. Essex inst., 1888, 20, p. 106.

Similar in its origin to the preceding, but confined to Cayman Brac. Until more material is available, it is impossible to settle definitely the status of these two species from the Cayman Islands. The type is No. 6,235, M. C. Z. This seems also little more than a color phase.

\section{Alsophis brooksi, sp. nov.}

Types:- No. 7,893, M. C. Z., two specimens (lacking tails). Little Swan Island, Caribbean Sea, March, 1912, George Nelson, collector.

This form which is simply an island race of the Cuban $A$. angulifer Bibron, comparable to $A$. fuscicauda Garman from Cayman Brac and A. caymanus Garman from Grand Cayman differs from all of these in coloration. The entire upper surfaces in the fully adult become completely suffused with dark brown, which becomes a solid color along the middorsal region. All of the scales of both half grown and adult specimens are heavily punctulated with dark brown. In the other races they are free from this characteristic spotting. The ventral scale counts for the two specimens, 182 and 183 show that the average condition for this form is evidently above that of the other races, their highest scale count, rarely observed, is 180 . 
This snake is not found upon Swan Island having been probably exterminated there by either the early settlers or the cats which they brought. Named for Dr. William A. Brooks, President of the Swan Island Commerical Company who aided Mr. Nelson throughout his trip.

\section{Alsophis rudii COPE.}

Cope, Proc. Acad. nat. sci. Phila., 1862, p. 74. Barbour, Bull. M. C. Z., 1904, 46, p. 60. Amer. nat. 1907,40, p. 231. Rosén, Lunds univ. arsskrift, 1911, 7, no. 5, p. 40.

This Bahaman ground racer, so closely allied to A. angulifer of Cuba, has been found so far only upon the islands of Eleuthera, New Providence, Long Island, and Green Cay. This erratic distribution suggests that it probably exists undiscovered upon many others. Thanks to Mr. Witmer Stone I have examined the type No. 3,472, Acad. nat. sci., Phila. of Cope's Diadophis rubescens; it belongs to this species.

\section{Alsophis rufiventris (DUM@riL ET BIBRoN). \\ DUмériL et Bibron, Erpét. gén., 1854, 7, p. 668.}

Of the types of this species one was said to have come from Brazil, and the other has no locality record. Garman refers specimens from St. Kitts, Saba, and Nevis, to this species while Boulenger (Cat. snakes Brit. mus., 1894, 2, p. 125) adds St. Eustatius to the list of localities. He includes Alsophis cinereus Garman and $A$. rijersmaei Cope, as synonyms.

\section{Alsophis cinereus Garman.}

Garman, Proc. Amer. philos. soc., 1887, 24, p. 282.

This form, which is closely related to A. rufiventris, but easily distinguished by having twenty-one rows of scales instead of twenty-three is found upon the islands of St. Bartholomew and Anguilla. The types are No. 6,139, M. C. Z.

\section{Alsophis rijgersmaei Cope.}

Cope, Proc. Amer, philos. soc., 1869, 11, p. 154.

Cope says, "So far as yet known, this distinct species is confined to the small island of St. Martins." There are no specimens in the collection here, so that I can not verify Boulenger's placement of this species as a synonym of A.rufiventris (Duméril \& Bibron). 
Alsophis porto-ricensis REINHARDT \& LÜTKEN.

Reinhardt \& LütKen, Vid. Meddel. nat. foren Kjobenh. for 1862, 1863, p. 221. Stejneger, Rept. U.S. nat. mus. for 1902, 1904, p. 700, fig. 170.

Closely related to $A$. antillensis. These species parallel in their distribution Leimadophis stahli and L. exiguus, since, like the former, this snake is confined to Porto Rico and Mona Island. L. stahli has not been found upon Mona, but doubtless occurs there.

\section{Alsophis melanichnus CoPE}

Cope, Proc. Acad. nat. sci., Phila., 1862, p. 76.

I have identified with this poorly described species a fine large male taken at Santiago de la Vega, San Domingo, by Mr. A. H. Verrill. After reading the following in Stejneger's Herpetology of Porto Rico (Rept. U. S. nat. mus. for 1902 , 1904, p. 701), I compared it carefully with his description of A. portoricensis. Stejneger writes:-

"The question whether Cope's A. melanichnus, from Haiti, is identical with the Porto Rican species can not be said to be settled yet. The scale formula seems to be the same, but it is not certain that there may not be other distinguishing features.....We have such startling proof of the effect of isolation working with a variable material to produce separate forms of these snakes that it is quite unwarrantable to lump the various names without incontrovertible proof."

Stejneger says the scale formula "seem to be the same" in this species and A. portoricensis. Cope, however, only mentioned the one fact that it had seventeen scale rows. Cope mentions No. 1,522, M. C. Z., from Jeremie, Haiti, as the type; but the specimen can not be found. Upon comparing our only specimen with Stejneger's description, or with a specimen of $A$. portoricensis, I find that the Haitian snake agrees in all characters, except in a very elongate loreal, much lower than high, and almost a rough triangle in outline, the base being anterior. It has two first temporals on each side, but these have the appearance of being the elements derived from an abnormally divided single scale. The ventral scales are 189 in number, and subcaudals 108 , the anal is divided. These counts will be seen to vary from the range and average of Stejneger's forty-four specimens from Porto Rico, which was 17 rows, 169-183 (average 178) ventrals, subcaudals 112-129. This combination of characters makes it seem almost certain that the Haitian species is perfectly distinct from, but very closely related to, the Cuban $A$. angulifer, as well as $A$. portoricensis. 
I am inclined to believe that Werner's Dromicus w-nigrun belongs with this species. It was described in 1909. (Hamb. jahrb. wiss. anst., 1909, 26, beih. 2, p. 222).

Alsophis antillensis (SCHLEGEL).

Schleged, Essai phys. Serp., 1837, 2, p. 214. Stejneger, Rept. U. S. nat. mus. for 1902, 1904, p. 704, fig. 171-174.

Like Leimadophis exiguus, this form is found upon.St. Thomas, St. John, and Culebra. The specimens which Garman recorded from Haiti (Proc. Amer. philos. soc., 1887, 24, p. 282) really belong to this species; and hence it must be concluded that in some way they have gotten their locality label misplaced. The species is, of course, in all probability not found on Haiti.

\section{Alsophis sanctae-crucis CoPE.}

Cope, Proc. Acad. nat. sci. Phila., 1862, p. 76.

This species replaces $A$. antillensis, of St. Thomas, upon St. Croix; to which island, so far as known, it is confined.

\section{Alsophis anomalus (Peters)}

Peters, Monatsb. Akad. wiss. Berlin, 1863, p. 282. Boulenger, Cat. snakes Brit. mus., 1894, 2, p. 125.

A very distinct species, confined to the island of Haiti.

Alsophis leucomelas (DUMÉRIL ET BIBRon).

Duméril et Bibron, Erpét. gén,, 1854, 7, p. 666. Boolenger, Cat. snakes Brit. mus., 1894, 2, p. 123 (part).

Originally described from Marie Galante and Guadeloupe. Boulenger adds the localities Antigua and Montserrat. No material representing this species is in the collection, so that it is impossible to say whether or not the snakes are the same on the different islands. The great variability which Boulenger speaks of is very likely due to the differences in color in specimens from the various islands. This character is often very diagnostic and unvarying among specimens from a single island.

Alsophis sibonius CopE.

Cope, Proc. Amer. philos. soc., 1879, 18, p. 275.

Apparently confined to Dominica, this snake appears to warrant separation from leucomelas of Duméril and Bibron, with which Boulenger Cat. snakes Brit. mus., 1894, 2, p. 124 has united it. The single specimen in the Museum agrees closely with Cope's description. 


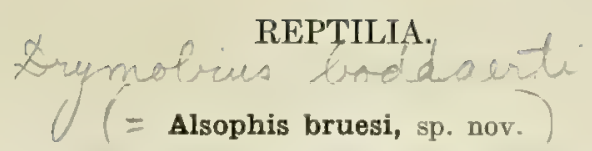

Type: - No. 7,792, M. C. Z., adult, near St. George's, Grenada, G. M. Allen and C. T. Brues, collectors. Six other specimens from the same source in the collection.

By a curious coincidence the only ground snake that either Brues or Allen obtained upon Grenada was a true Alsophis having scales in seventeen rows and with two distinct pores in each one. This species they found rather abundant, and they brought back seven fairly well-preserved examples. Neither Garman nor any other collector, apparently, has hitherto found this genus upon Grenada. Undoubtedly some peculiarity of habit or habitat has enabled it not only to survive in spite of the presence of the mongoose, but to become, apparently, the most abundant ophidian on the island.

Rostral much broader than high, scarcely visible from above; internasal suture a little shorter than prefrontal suture; frontal equal to its distance from end of snout, shorter than parietals, separated from preocular by only a short interspace; supraocular at its posterior margin almost equal in width to the anterior margin of frontal; nasal divided, shorter than its distance from eye; loreal a little more than twice as long as high, an almost perfect rectangle; a large preocular; two postoculars, lower smaller than upper; a large anterior temporal, with almost always a small scale intercalated above it, anteriorly. In the type this small scale has a lower position on one side so that one small temporal seems to be followed by the larger one. Two large temporals follow; nine supralabials (in all specimens), second and third in contact with tabiat 6 fourth with preocular, and slightly entering orbit; five and six in orbit; nine or ten lower labials, five in contact with anterior chin shields; anterior chin shields scarcely more than half as long as posterior; scales smooth, in seventeen rows, each with two conspicuous apical pits; ventrals 198, anal divided; subcaudals in 121 pairs. Length of body $700 \mathrm{~mm}$., tail $310 \mathrm{~mm}$. Color (in alcohol) above uniform olive-drab or slightly darker, below whitish or light slatey gray, with two lateral white lines on the ventrals, which may have slightly darker margins. Throat usually yellowish, the fourth scale row on each side light in color; a dark loreal band generally extending for some distance behind the eye.

Variations:- A young specimen about $400 \mathrm{~mm}$. in total length has each side margined with blackish, and light lateral line covering the fourth and half of the fifth row of scales. The characteristic squamation and coloration is remarkably stable. The largest specimen, which is not as well preserved as the type, measures $760 \mathrm{~mm}$. in total length, and 320 in length of tail. The range of 
variation in the scale counts is shown by the following numbers taken from the cotypes: - ventrals 201, subcaudal pairs (tail imperfect); ventrals 199, subcaudal pairs 127 ; ventrals 194 , subcaudal pairs 125 ; ventrals 205 , subcaudal pairs 120; ventrals 205, subcaudal pairs (tail imperfect); ventrals 193 , subcaudal pairs 121 . In every case the anal is divided. The range then may be expressed as v. 193-205; subc. $120-127$ pairs.

Leimadophis ater (GossE).

Gosse, Naturalist's sojourn in Jamaica, 1851, p. 228. Barbour, Bull. M. C. Z., 1910, 62, p. 300.

A snake which has been practically exterminated by the mongoose. It was formerly abundant upon Jamaica, but has not been found at all by recent collectors.

Leimadophis callilaemus (Gosse).

Gosse, Naturalist's sojourn in Jamaica, 1851, p. 384. Barbour, Bull. M. C. Z., 1910, 62, p. 300.

Another species which, though it has become rare, has not yet been quite extirpated by the mongoose. It is confined to Jamaica.

Leimadophis andreae REINHARDT \& LÜTKXN.

Reinhardt \& LÜtken, Vid. meddel. nat. foren Kjöbenh. for 1862, 1863, p. 214. Boulenger, Cat. snakes Brit. mus., 1894, 2, p. 140.

The rather complicated synonymy of this species seems to have been settled satisfactorily by Boulenger. The species is confined to Cuba, and is represented in the collection here by the specimens which were collected by F. Poey and which served Garman for the types of his synonymous Dromicus cubensis (Proc. Amer. philos. soc., 1887, 24, p. 280). Besides these we secured a series by following ploughs on the Soledad sugar estate, near Cienfuegos. This species seems to spend much of its time burrowing under ground or hiding under stones.

Leimadophis temporalis (COPE).

Cope, Proc. Acad. nat. sci. Phila., 1860, p. 370. Boulenger, Cat. snakes Brit. mus., 1894, 2, p. 143.

A well defined and apparently very uncommon Cuban species. Garman (Proc. Amer. philos. soc., 1887, 24, p. 281) believes that this is the species figured by Jan as Dromicus nuntius. Boulenger, however, (loc. cit., p. 181) identifies the latter species with Urotheca lateristriga, from Central America. Cope states that the type is in this Museum. The only specimen is No. 297. This is beyond doubt the typical specimen, although it bears no contemporary type label.

I have never found this species in the parts of Cuba where I have collected. 


\section{Leimadophis parvifrons (CoPE).}

Cope, Proc. Acad. nat. sci. Phila., 1862, p. 79. Botlenger, Cat. snakes Brit. mus., 1894, 2, p. 141.

This species is confined to Haiti. The types are No. 3,602, M. C. Z. It was among the collection made by Mr. A. H. Verrill at Santiago de la Vega, San Domingo, and in Mr. W. M. Mann's collection there are many specimens from Diquini, St. Marc, Cape Haitien, Manneville, and Grand Riviere, Haiti.

Leimadophis cursor (LACÉPÈDE).

LACEpédÈ, Hist. nat. quad. ovip. et serpens, 1789, 2, p. 96, 281, pl. 14. Botlenger, Cat. snakes Brit. mus., 1894, 2, p. 139 (part).

Apparently common upon Martinique, whence Garman recorded many specimens (Proc. Amer. philos. soc., 1887, 24, p. 280). Boulenger includes two specimens from Guadeloupe, which quite likely represent a different race.

Leimadophis boulengeri, nom. nov.

This is the Dromicus ornatus of Garman (Proc. Amer. philos. soc., 1887, 24, p. 281). His specific name is apparently preoccupied by Coluber ornatus Shaw (Zool., 1802, 3, p. 477), which evidently belongs to this genus.

The new name is given in honor of Dr. G. A. Boulenger, of the British museum, to whom I owe a vast deal for kindly hospitality and assistance.

This St. Lucia species is easily distinguishable from that of Martinique (A. cursor) by having fewer pairs of subcaudal scales, 85-91 as against 101-107. The types are No. 6,135, 6,136, 6,137, M. C. Z.

\section{Leimadophis stahli SteJneger.}

STEJNEGER, Rept. U. S. nat. mus. for 1902, 1904, p. 695, fig. 161-166.

This species, which has formerly been confused with $A$. parvifrons (Cope) from Haiti, is related to that species, but perfectly distinct, and confined to Porto Rico.

\section{Leimadophis exiguus (COPE).}

Cope, Proc. Acad. nat. sci. Phila., 1862, p. 79. Stejneger, Rept. U. S. nat. mus. for 1902, 1904, p. 698, fig. 167-169.

This snake, closely related to the preceding, replaces it upon the islands of St. John and St. Thomas. It has recently been found upon Culebra; and, as Stejneger suggests, it probably occurs upon Vieques as well. 
Leimadophis juliae (COPE).

Cope, Proc. Amer. philos. soc., 1879, 18, p. 274. Bodlenger, Cat. snakes Brit. mus., 1894, 2, p. 139.

A fine species, which has been found abundantly upon Dominica.

The difference in color which Garman has mentioned (Proc. Amer. phil. soc., 1887, 24, p. 281) is very conspicuous in specimens from this island and Marie Galante, and there seems to be no reason why, if this is found to be the case in large series, the Marie Galante species should not be considered a valid race. It may be called

Leimadophis mariae, sp. nov.

The types are No. 6,138, M. C. Z. The characters have already been given by Garman.

\section{Leimadophis perfuscus (COPE).}

Cope, Proc. Acad. nat. sei. Phila., 1862, p. 77. Bodlenger, Cat. snakes Brit. mus., 1894, 2, p. 133.

A well-defined species confined to Barbados.

Leimadophis melanotus (SHAw).

Shaw, Zoology, 1802, 3, p. 534. Boulenger, Cat. snakes Brit. mus., 1894, 2, p. 134.

This mainland species has been recorded from Grenada by Garman (Proc. Amer. philos. soc., 1887, 24, p. 282).

Allen did not obtain a single specimen, and it has probably gone the way of most of the ground-inhabiting ophidians of the island.

Boulenger includes within this species specimens from Colombia, Venezuela, Trinidad, and Tobago.

Urotheca dumerilii BiBRoN.

Bibron, Sagra's Hist. Cuba. Rept., 1843, p. 218, pl. 24. Boulenger, Cat. snakes Brit. mus., 1894, 2, p. 181.

This snake is of peculiar interest if it is really the only Antillean species existing on the Central American mainland. Neither Gundlach, Charles Wright, nor any recent collector has succeeded in finding this species upon Cuba. As with so many of the Cuban species sent to Paris by Sagra, it may really be confined to the Central American mainland. The only specimen of the species in this Museum was one sent by A. Aug. Dumeril from the Paris museum. It was said to be a "type" in the loose sense in which the word was then employed and may really represent one of the original series which probably did not come from Cuba. 


\section{Arrhyton taeniatum GüNTHER.}

Günther, Cat. snakes Brit. mus., 1858, p. 244. Bodlenger, Cat. snakes Brit. mus., 1894, 2, p. 252.

This was the first known species of this remarkable genus peculiar to Cuba. In 1894, only the type was preserved in the British museum, and it still seems to be extremely rare. In January, 1913, I procured a fine example from near Cojimar, not far from Havana.

\section{Arrhyton vittatum (GUNdLACH AND Peters).}

Gundlach \& Peters, Monatsb. Akad. wiss. Berlin, 1861, p. 1002. Bodlenger, Cat. snakes Brit. mus., 1894,2, p. 252.

Another rare Cuban species. The collection contains a typical example from Soledad, near Cienfuegos, Cuba. It was given me by Mr. R. M. Grey, who caught it in the Harvard Botanical Experiment Station. Mr. Barnum Brown caught another example near the Rio Analla, Cuba, which is now in this Museum.

\section{Arrhyton redimitum (CoPE).}

Cope, Proc. Acad. nat. sci. Phila., 1862, p. 81. Boolenger, Cat. snakes Brit. mus., 1894, 2, p. 252.

Apparently equally as rare as the preceding species. Also Cuban. I am rather inclined to believe that these three species may in reality all represent one variable form and be referable to a single species. Much more material is needed to settle this point.

\section{Clelia cloelia (DaudiN).}

Daudin, Hist. nat. rept., 1803, 6, p. 330, pl. 78. Boulenger, Cat. snakes Brit. mus., 1896, 3, p. 108. Oxyrhopus plumbeus Wagler. Gǘnther. Garman, Proc. Amer. philos. soc., 1887, 24, p. 285.

The specimens upon which Garman based his record for Oxyrhopus plumbeus Wagl., Günther are in excellent preservation. No special comment upon them is necessary. Allen obtained no specimens, and did not even hear of the species, from which we may assume that it has either grown very rare or become extinct. Garman's example seems to be the only one known from Grenada; he had two others, also fully adult, from St. Lucia. Boulenger (Cat. snakes Brit. mus., 1896, 3, p. 109) records specimens in the British museum from St. Lucia and Dominica. As is well known, this is a wide-ranging species, occurring through tropical America from about the City of Mexico to southern Brazil. In first recording these specimens from Dominica Boulenger (Proc. Zool. soc. London, 1891, p. 352), remarked that they were "hitherto recorded only from Trinidad in the West Indies." Garman's West Indian records were published some years earlier. 
Fitzinger's name Clelia, based on this very species of Daudin, antedates the name Oxyrhopus of Wagler, in common use, by four years.

Pseudoboa neuweidii (Duméril et Bibron).

Duméril et Bibron, Erpét. gén., 1854, 7, p. 1001. Boulenger, Cat. snakes Brit. mus., 1896, 3, p. 112. Scylale coronatum Schneider. Duméril et Bibron. Garman, Proe. Amer. philos. soc., 1887, 24, p. 285.

I have followed Boulenger (loc. cit.) in using this name for the three small snakes (No.4511, M. C. Z.), from Grenada which Garman collected and recorded. They agree perfectly with Boulenger's description of neuweidii, while they may be distinguished at once from Schneider's species, coronatus, in that they have each nineteen and not seventeen rows of scales. The original neuweidii of Duméril and Bibron was apparently a composite species, and it has been divided by Boulenger into the above form and 0 . guerini Duméril and Bibron. There is no material at hand by which to verify this separation, but from Boulenger's descriptions this solution of the question would seem to be excellent.

The species has been taken only this once in Grenada, so far as I can find published record. It is probably the same species as that recorded from Trinidad by Mole and Urich (Journ. Trinidad field nat. club, 1894, 2, p. 86) as Scytale coronatum Schneider. It seems to be confined to these islands, besides being widespread on the mainland. Its occurrence is to be expected on Tobago. The fact that neither Allen nor Brues found or heard of it in Grenada last year would suggest that it has probably been exterminated by the mongoose.

I believe with Stejneger that the possession of undivided subcaudals is a character of sufficient importance to warrant our separating these species generically from Clelia (Oxyrhopus auct.). Stejneger has shown that Pseudoboa is an available name for these species (Proc. U. S. nat. mus., 1902, 24, p. 187-188).

\section{Ialtris dorsalis GüNTHER.}

Günther, Cat. snakes Brit. mus., 1858, p. 126. Boulenger, Cat. snakes Brit. mus., 1896, 3, p. 137.

The only specimens in the collection are the two from Jeremie, Haiti, collected by Dr. D. F. Weinland, which served Cope as types for his $I$. vultuosa (Proc. Acad. nat. sci. Phila., 1862, p. 73). They are No. 3,600, M. C. Z., although Cope in the original description gave them as No. 1,519, M. C. Z. This was the number from the old catalogue, which was long since discontinued, unfortunately giving rise to confusion of numbers, and making the identification of some of the early types a matter of difficulty. 


\section{Lachesis lanceolatus (LACÊPÈDE).}

LACÉPÈDE, Hist. nat. quad. ovip. et serpens., 1789, 2, p. 98, 119, pl. 4, fig. 1.

There has long been question as to the real distribution and occurrence of the "Fer-de-Lance" in the West Indies. It is probably at present confined to the islands of Martinique and St. Lucia. Labat, in his Nouveau voyage aux Isles de l'Amerique (La Haye, 1722, 1, p. 429) makes it quite clear that he knew this snake well. He says, after remarking on the venomous character of a snake which he killed in his hen-roost one morning:-- "Pour peu qu'on soit fait au pays on distingue aisément la couleuvre d'avec le serpent, parce que la couleuvre a la tête longue et ronde comme une aiguille, \& que le serpent l'a plate, \& presque triangular." This quotation, showing that the good Father was quite sound in his identification, was followed later in his narrative (4, p. 105) by the following interesting statement:- "On n'en voit (des serpents viperes) dans toutes les Antilles qu'a la Martinique, Sainte Alonsie où Lucie \& à Bequia, qui est un des Grenadins, qu'on appelle a cause de cela, la petite Martinique... . On ne voit dans les autres Isles que des couleuvres qui ne sont point venimeuses, \& qui même sont utiles, en ce qu'elles font la guerre aux rats. Eiles [sic] sont rares à la Guadeloupe, et même fort petites." In connection with these quotations, we may well observe also what Symington Grieve says in his Notes upon the island of Dominica (London, 1906, p. 63-64): - "Of snakes there are at least three kinds, one of which - the tetche - grows to a large size; and I was told of specimens of from fourteen to twenty feet in length. But the usual size, of which I saw several, and killed one, was about six or seven feet. The other two varieties I saw were quite small, and none of the snakes on Dominica are believed to be poisonous." So much then for the occurrence of this extremely well-known and conspicuous species upon Guadeloupe and Dominica. Yet Boulenger (loc. cit.) in his Catalogue records specimens in the British museum from both these islands. Were they like so many other specimens recorded from this region, caught upon one island, but shipped to the Museum from another? As for the occurrence in the Grenadines which Labat mentions, it can only be said that the species does not apparently exist there now; while the names of Bequia and Petit Martinique are used for two different islands.

Regarding the identity of the West Indian Fer-de-Lance with that of the mainland, the characters which Garman gives for his L. caribbaeus (Garman) from St. Lucia do not seem distinctive. Yet there can be no possible doubt but that St. Lucia specimens (Types No. 4,812, M. C. Z., and in British museum) range lower in scale rows - twenty-five to twenty-seven rows in five specimens - 
than do those from Martinique, twenty-nine to thirty-three rows in six specimens. Thus apparently the Dominican specimen recorded by Boulenger probably came from St. Lucia (having twenty-seven rows), and the Guadeloupe specimen from Martinique (having thirty-three rows), which is exactly what one would expect from the fact that the pairs of islands are respectively British and French.

While it is quite possible that the study of a large series of St. Lucian examples would firmly establish the fact that there was a peculiar species upon the island for which Garman's name is available, it is quite impossible to recognize this race, and then to identify the snakes from Martinique with those of the mainland. This would convey an entirely false impression; as to their origin and relationship. The individuals on both islands are all derived from the lanceolatus stock, which is widespread upon the mainland. Until more material is available, it is impossible to attack this problem satisfactorily. We can not, however, recognize a peculiar form which divides the range of the widespread species. This would be contrary to what we hold to be a zoögeographic law.

Since the preceding lines were written, I find that Mr. A. E. Brown has recorded the scale counts for two specimens which were once brought alive to the Philadelphia Zoological gardens, and which were said to have come from Martinique. In these the scale rows were twenty-five in number. This fact, coupled with the long known and singularly frequent inaccuracy of locality data accompanying living specimens, which are shipped about from place to place until they reach their final destination, is enough in itself to make it appear very probable that these were really St. Lucian specimens.

\section{Chrysemys palustris (GMELiN).}

Gmelin, Syst. nat., 1788, 1, p. 1041.

Chrysemys var. rugosa (Shaw). Boulenger, Cat. ehelonians, ete., Brit. mus., 1889, p. 79.

Chrysemys scripta palustris GM. Siebenrock, Zool. jahrb. Suppl. 1909, 10, p. 464.

This somewhat variable form is the only fresh water tortoise occurring in the West Indian area. I have followed Stejneger (Rept. U. S. nat. mus. for 1902, 1904 , p. 710) in ranking this form as a full species. There are specimens at hand from Jamaica (type locality), Cuba, Haiti, and Porto Rico. They do not, however, vary in such a way as to warrant the designation of varieties confined to each island. Stejneger and I (Bull. M. C. Z., 1910, 52, p. 301) had both expected that such subspecies might be defined. As yet, however, the material available for study is very meagre. The species is very shy, and is usually confined to lowland muddy ponds.

Siebenrock (loc. cit.) follows Boulenger (loc. cit.) in recording the species 
from both Guadeloupe and Martinique. There is no reason whatever for supposing that the species occurs on either of these islands. This tortoise was reported by Maynard as occurring on Grand Cayman Island, probably by importation from Cuba. It has not been found by more recent collectors. It is common in most fresh water ponds all over Cuba and Jamaica. It frequently finds its way into the Cuban markets.

\section{Crocodilus rhombifer Covier.}

Cuvier, Ann. Mus. hist. nat., 1807, 10, p.51. Boulenger, Cat. chelonians Brit. mus., 1889, p. 237.

This species is confined to Cuba, whence the Museum has several specimens. It is locally known as "Cocodrilo." It is very closely related to Crocodilus moreletii, A. Dumeril of Guatemala and Honduras, - a rare species from which the Cuban form has doubtless been derived. Quoting from the field notes of Mr. C. J. Maynard, Garman (Bull. Essex inst., 1888, 20, p. 108) records the following in writing of the herpetology of Little Cayman Island:- "Two species of crocodile have been taken on this island, and one on Cayman Brac. I saw but a portion of one specimen. The natives assured me the species were similar to those found in Cuba." The species referred to are doubtless this and the succeeding. Whether they are resident in the Cayman group, or whether they only reach the islands occasionally by swimming would be well worth ascertaining definitely. As yet no answer to this question can be given.

This crocodile is apparently entirely confined to the submerged regions of the Cienaga de Zapata and the Cienaga of the Isla de Pinos. I found it abundant in 1913 about the Laguna de Punta Gorda not far from where the Rio Hanabana enters the great swamp. The three which I killed were from five to seven feet long, but it grows much larger. In the Museum of the Institute of Secondary Education in Havana there is an enormously massive skull taken by Gundlach from a specimen nearly seventeen feet long. This species is very aquatic living in the floating vegetation and half floating reed beds of the "tembladera" in the Cienaga. In the region which I visited the swamp had a hard firm substratum upon which was overlaid from two to five feet of very soft liquid mud and on the surface of this half afloat were the great reed beds with more open areas of stagnant water and lily pads of several sorts. This region supported an enormous population of water fowl and waders as well as the crocodiles, which hide among the roots of the cat tails when disturbed, or sun themselves upon the floating beds of matted lily pads and water plants. 
LAURENTI, Syn. rept., 1768, p. 54. Botuenger, Cat. chelonians, Brit. mus., 1889, p. 281.

This is the most common crocodilian of the West Indian region. It was formerly abundant in Jamaica, though now it is largely restricted to the swampy deltas about the mouths of the Milk River and Black River. It occurs in a few other favorable localities, but is rare everywhere. It is generally called the "alligator," but the name of "crocodile" is also quite widespread. In Cuba it is more common, and occurs widely distributed in suitable localities. It is generally known to the natives as Caiman, in contradistinction to "Cocodrilo," a name used for the other Cuban crocodile ( $C$. rhombifer Cuvier). In Haiti it is said to be common, but of its occurrence in either Haiti or San Domingo practically nothing is known. Outside of the Greater Antillean region it ranges through Mexico, Central America to the Pacific coast region of Ecuador. In Florida, whence it was first made known by Jeffries Wyman (Amer. journ. sei. arts., 1870,49 , p. 105-106), it is now very rare. Its persecution by local hunters has practically exterminated it about Biscayne Bay, and left but few individuals about Cape Sable and among the northern Keys.

There are specimens in the Museum from Florida, Cuba, Haiti, Jamaica, Mexico, Honduras, Nicaragua, and from both sides of the Isthmus of Panama. 




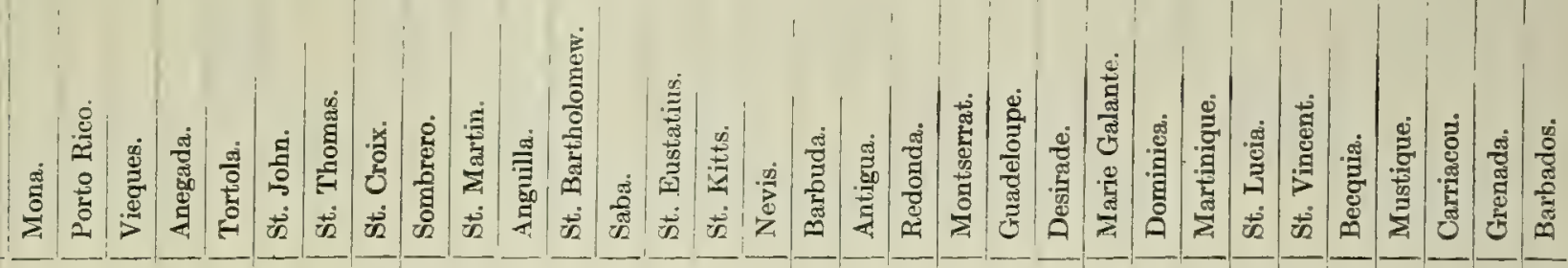



REPTIL:

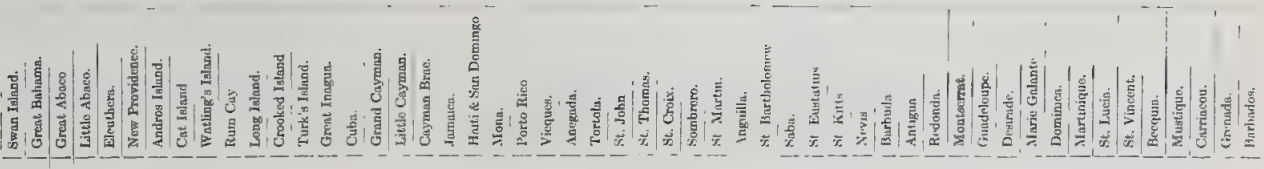

Aristelliger prucsignis (Hillowoll) Aristelliger hir Cope

Ariotrlliger nelsoni Barbour

Tarancoln cubuns Gundlach \& Petere

Sphacenodactyius torrei Barbour

Sphnerodactylus elegaru Reinhardt \& Lotken

sphnerodactylus einereus Cootcau

Sphacrodactylus nigropunetatus Gray

Sphremdactylus decomene Garmnn

Sphaserodactylu fingicaudua Barbour

Spheerodactylus alopex Cope

Sphnerodactylus oxyrrbinus Gasene

Sphererodactylus argus Gosso

Sphnerodactylus areivun Garme

Sphserodactylus notatus Bsird

Sphserodactylus exsul Barbour

Sphacerodactylus difficilia Barbour

Sphiserodsctylua corticolus Garman

sphnerodactylus goniorhynchus $\mathrm{Cop}$

Sphscrodactylus gilvitorques Cope

phenerodactylus copii Steindachner

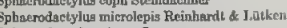

Sphacrodactylus pictus Garman

Sphaerodactylus vincenti Boulenget

Splaserodactylua melanospilus Bocon

Sphrarodactylus rietuardsonir Gray

Sphacrodactstylus asper Cuman

Splancodadactylua graodisquamis Stejareger

Spancrodactylua gracdiequamio stejater

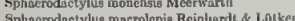

Aphnerodsetylus Enutator (Sparrman)

Chanıeoleolis ehamseleantidles (Dum fril \&s Bilron)

Xiphacerets valenciennegii (Duthén' at Bibron)

\section{Anolis equestris Méerrem}

Anolis karmani Stejueger

Anolì euvierí Merrom

Anolis gundlachi Peter

Anolis eristatellus Duméril ae Tjihron

Anolis atmatulus Copo

Anolis homolechis Cop

Anolis gingivinum Cope

Anolis allianous Cope
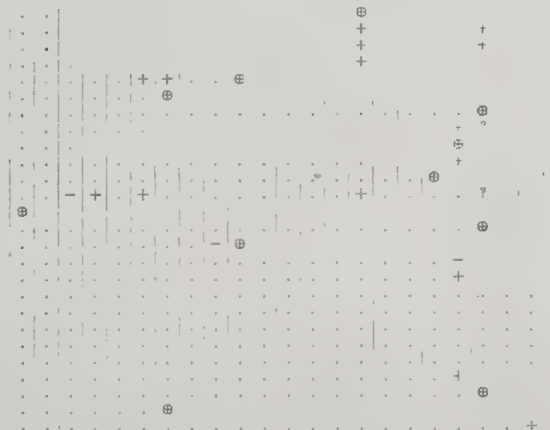

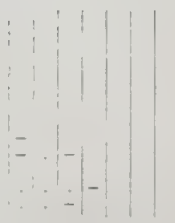





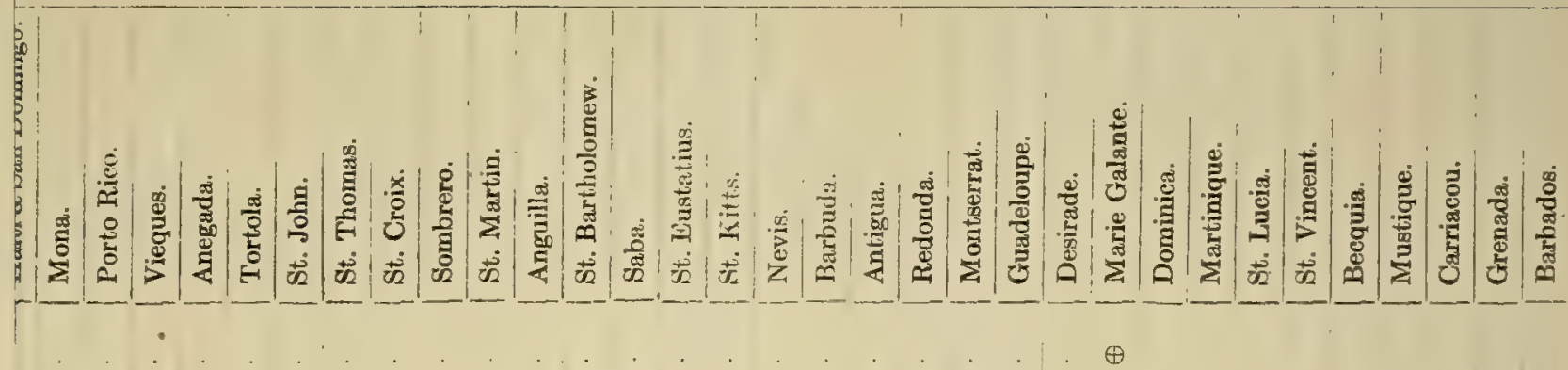

$\dot{\oplus}$ 

REтTLA

Anolis nqper Garman Anolis speciosue Garman Anolis lyvidus Garman Anolis sabanus Garma Anolis leschii Dumeril \& Bjbror Anolis espediti Merrem Anolis ecpedti Merrem Anolis vineentii Grmm Asolia lueine Garman Anolía extremus Garma Anolis marmorntus Duméril \&s Bibron Anolis bimaculatug (Sparrmen) Anolss richardiii Dueseril \& Bibron Anolis trossulua Garman
Anolis trintatia Reinbardt \& Latken Abolis grahnmif Gray Anolis opalinus Gous Anolis iodurus Gosese Anolis conspersus Garma Anolis distichus Cope Anolis cyboten Copo Anolis cybotes Copo

Anolis citrinellus Cope

Anolis poncensis \& teju

Anolis cyermanni Stejner Amolis krugi Peters Anolis isolepis Copo Anolia luciua Duméril \& Bibron Anolis argenteolus Cope Anollis waltai Bouleager Anolis lineatopus Gray Anolis sagrei Duméril \& Bihron Anolis ordinatus Cope Anolis nelsoni Barbour Anolig groyi Barbour Anolia bretren Barbour

Anols luteosiguifer Garman Rnolis varmiculntus Durn Anolis loysisnn Cocteal

Anolis argallaceut Cope

Anolia semilinestus Cop

Anolis cyanopleurus $\mathrm{Cop}$

Anolis nlut tacens Cope Anolis augus ticepg Hillowell

Anolis porcatus Gray Anolia mugyandi Garan Anolis brunneua Cope 



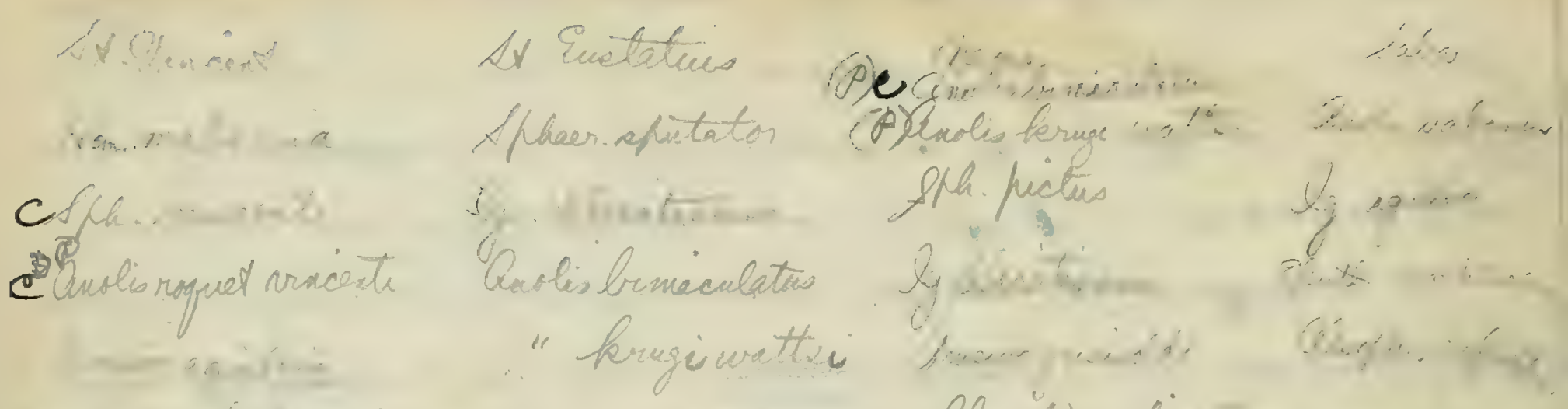

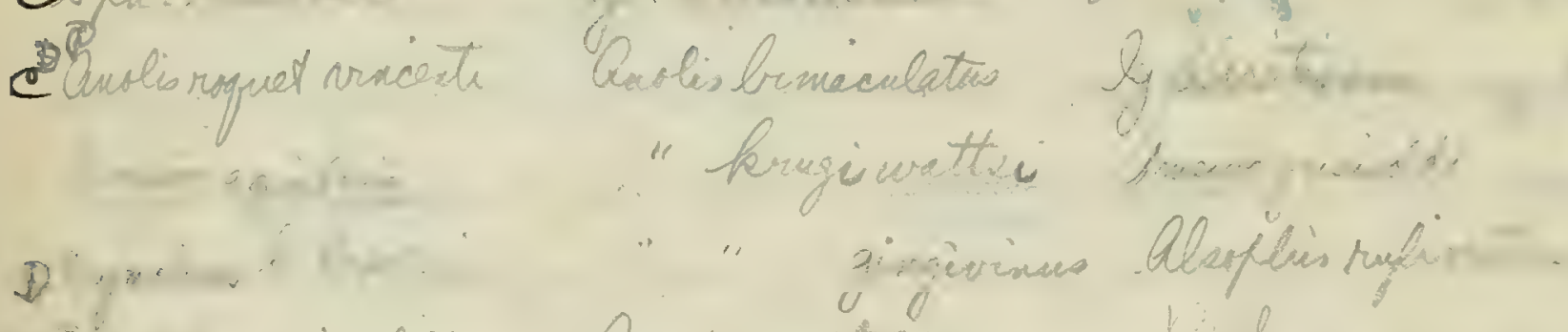

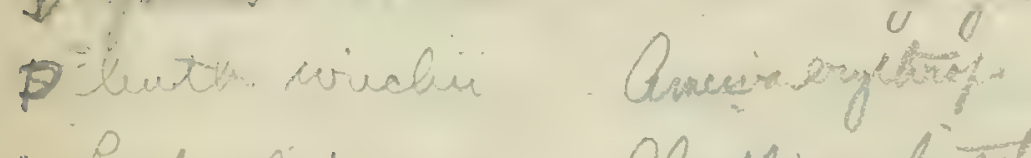

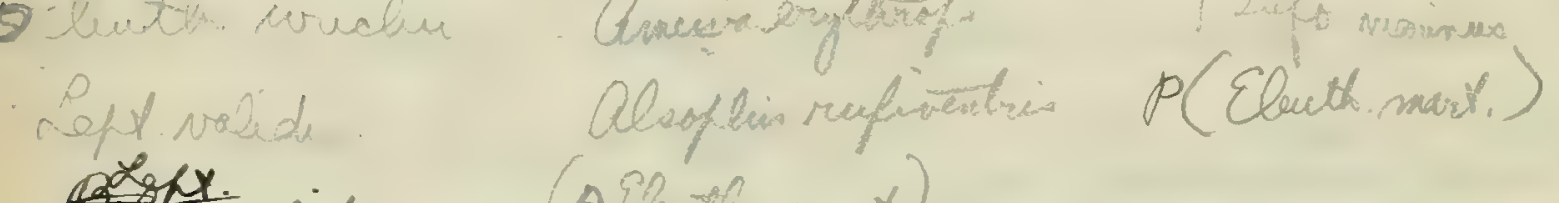
validus (Plouth.mait)

(p.eleuth mart.)

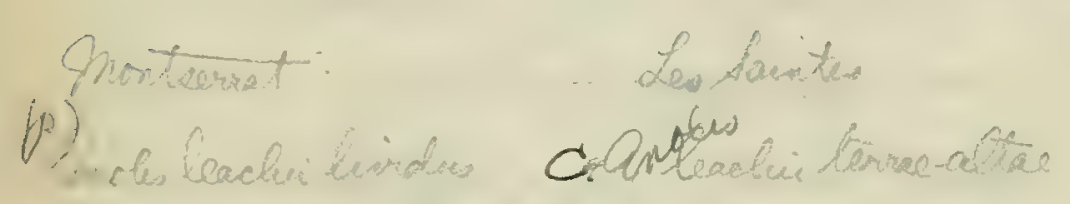

7)

c $P($ Eleuth max.

$(P \forall \ldots, \ldots, \ldots)$

$(1-16$, nopucads)

(P) yhal jam)

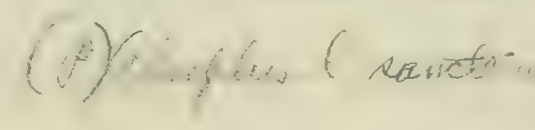

Hen maluriss

Ther rafuarides Cholish leachas

Anolis rechardii tis Emaira ennerecea

Anoles richardii $\overline{\text { Tyblpotominuame }}$

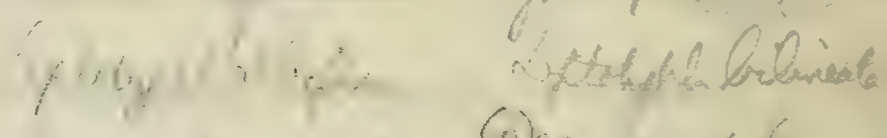

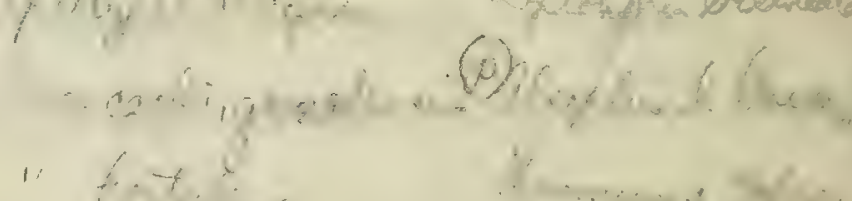

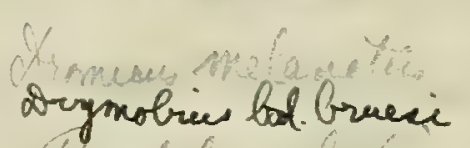

Bept.

Elewseh. Johnotorei

Bufo marinus Sirbcosaures allerie 
Eless Reptilia

Erdes squamata

Auborder berpentes

Famiby Jypalogedas

- Tyńlopo lumbricalis

2 "hucilius

Firnily soibac

3 Excrates ibratus Nituatus

4 unoriates fóolic

5 ". qracitis qracilis

6 Trofedioflis mscuiatus hasteasus

Farién Coubridae

7 Ciromacer catecífi

\&

9

15 - candax

Crenaties

wetmorei

1" " dorealis

12 " opyrhynches

1s Hepreirhynchus Lerox

14. Vleophis anomalis $15 \%$ melanechnes

is Aromecus areifrons Excimi

17

nejer

18

iariperose

- horlenves

¿o

" aléni

21

" Tortuganos

22

- rosamordac

Cowen 


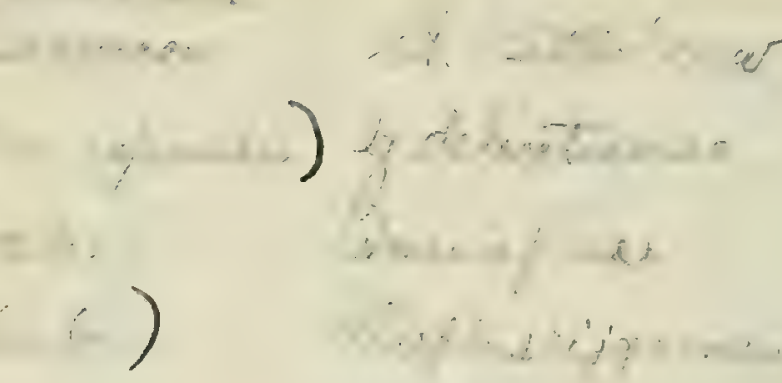

Onolesgingivinues

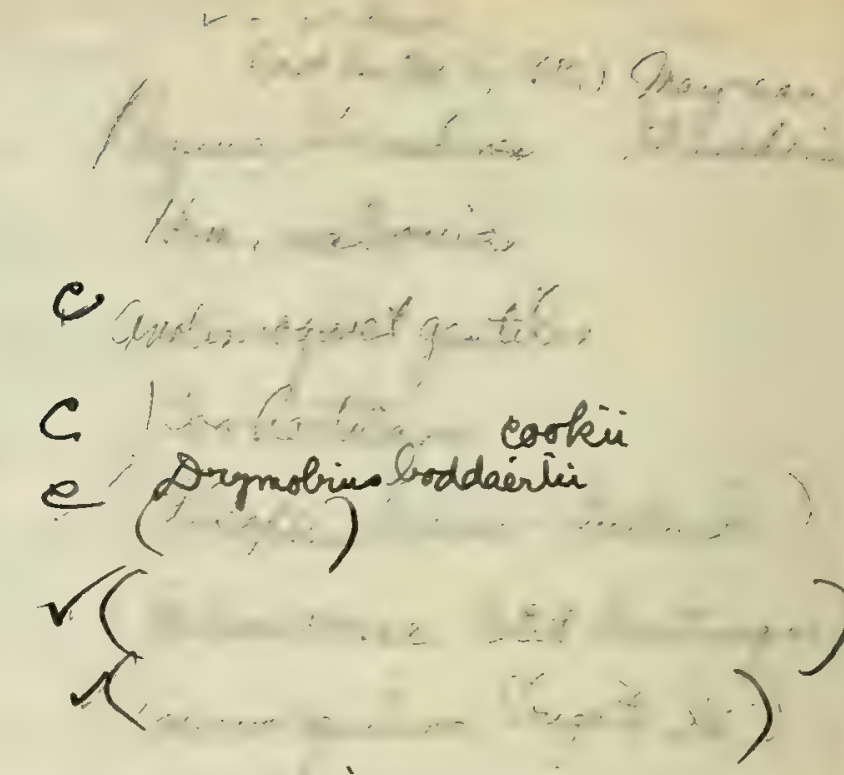

Anolis rechardii

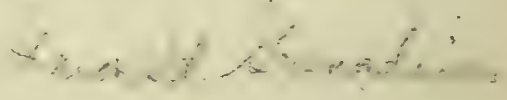

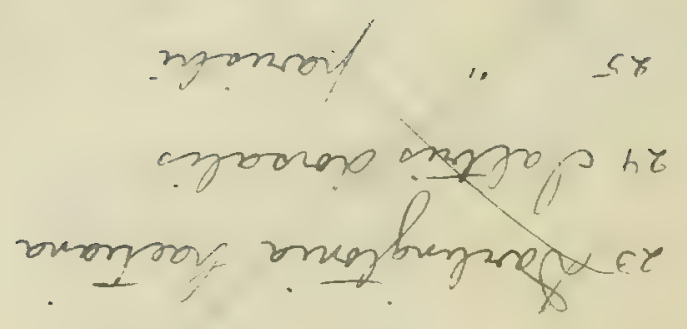


BARBOUR: ZOÖGEOGRAPHY.

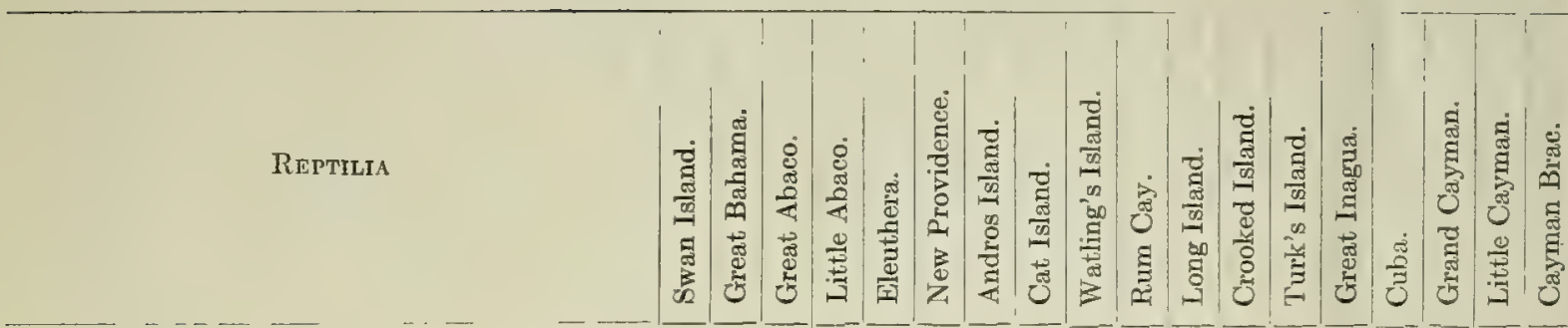

Anolis oligaspis Còpe

Anolis leucophaeus Garman

$-=?$

Anolis chlorocyanus Duméril \& Bibron

Anolis pulchellus Duméril \& Bibron

Norops ophiolepis (Cope)

Iguana rhinolopha Wiegmann

Iguana delicatissima Laurenti

Cyclura cyclura (Cuvier)

Cyclura collei Gray

Cyclura baeolopha Cope

Cyclura rileyi Stejneger

Cyclura cornuta (Bonnaterre)

Cyclura carinata Harlan

Leiocephalus carinatus Gray

Leiocephalus virescens Stejneger ${ }^{l}$

Leiocephalus varius Garman

Leiocephalus loxogrammus Cope

Leiocephalus vittatus (Hallowell)

Leiocephalus macropus Cope

Leiocephalus schreibersii (Gravenhorst)

Leiocephalus melanochlorus Cope

Leiocephalus personatus Cope

Leiocephalus eremitus Cope ${ }^{2}$

Leiocephalus herminieri (Duméril \& Bibron)

Celestus sagrae Cocteau

Celestus sepoides (Gray)

Celestus pleii Duméril \& Bibron

Celestus impressus Cope

Celestus occiduus (Shaw)

Celestus rugosus Cope

Celestus crusculus (Garman)

Celestus maculatus (Garman)

Celestus costatus (Cope)

Cricosaura typica Gundlach \& Peters

Centropyx intermedius Gray

Ameiva auberi Cocteau

Ameiva doraalis Gray

Ameiva thoracica Cope

Ameiva chrysolaema Cope

Ameiva taeniura Cope

Ameiva vittipunctata Cope

Ameiva maynardi Garman

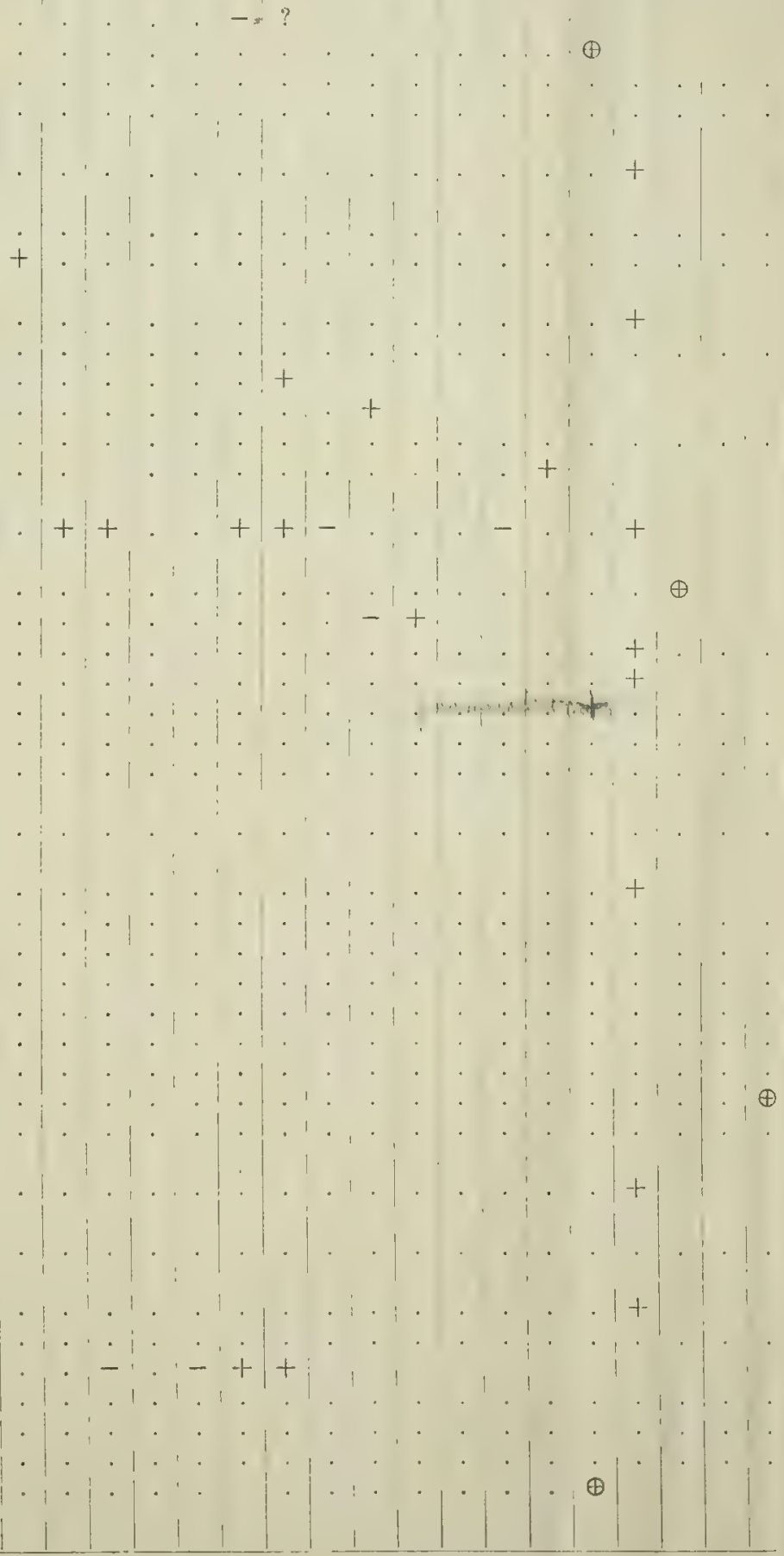

${ }^{3}$ Found on Green Cay, south of New $\operatorname{Pr}$ 

Anolus olignspis Copo Anoits lencophratuts Garmun Anolas elatorocyanus Duméril \& Bihran Anolis pulchellus Dundéril \& Bibran

Notops ophiolepis (Cope)

Igunas shinoloplan Wiegrmann

Cycluna cyclura (Cuvier)

Cyclura colles Grny

Cyclura baeolopha Cope

Cyclum riloyi stejneger

Cycluro cornuta (Bonnuterro)

Cydura earinata Fiarlao

Leioeephalua cariuatue Gray Leiocophalus vimeceens Stojucger Lejoceplialus varius Gartanan

Leioceplualus loxogrammus Cope

Leiveephatura vithatus (Hailoweit)

Leiocephulus achreibersii (Gravenhonat)

Leiocephusus achréberssi (Gravenlib

Leiocephal ua anclanochlorus Co
Luioeephalus personatua Cope

Lacephalus personatus Cope

Liocephalus horminiesi (Duméril \&s Bibron)

Culestus sngras Coctonu

Colostus sepoides (Gray)

Celestus pleil Dumberil \& B

Celestus inaptexs us Coppe

Celcestus occidurs (Bhina)

Celeatue crusculus (Garman)

Celestus maeulatus (Garman)

Celegtua sostutus (Copo)

Cricosaru typies Gundthel \& Peter

Centropyx intermedius Gny

Ameiva auberi Cactean

Ameiva doranlis Gray

Amiaiva thorseica Cone

Ameivas ohrysolscme Copo

Ameiva teeniura Copo

Ameiva viltipunetata Copo

Ameiva maynardi Garman

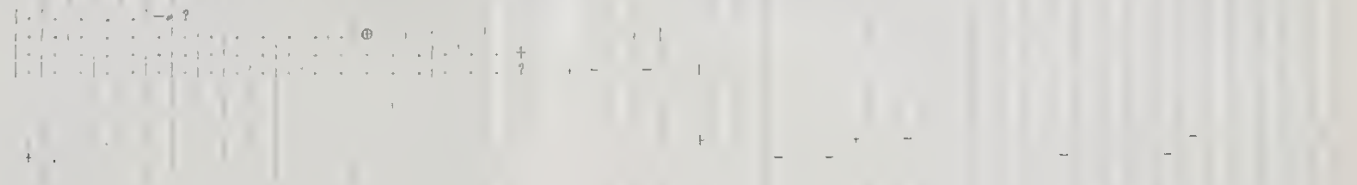




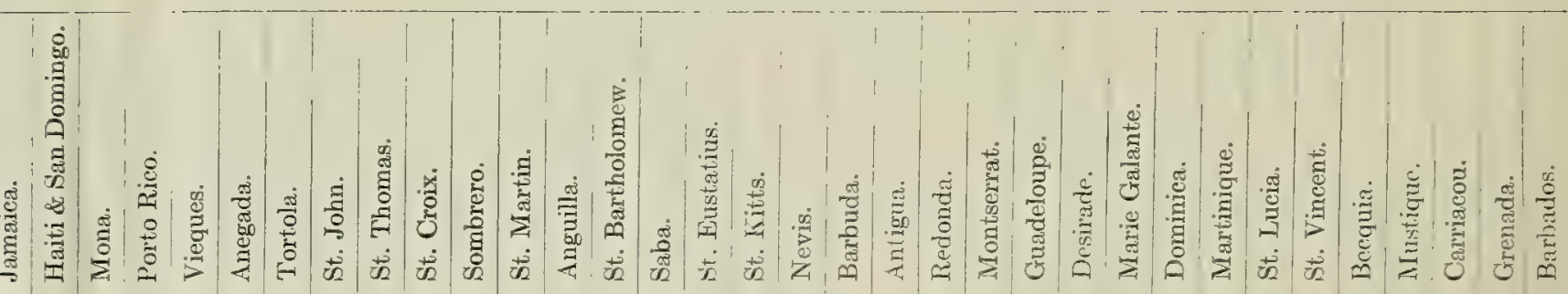

$\stackrel{+}{?} \cdot+-\cdot-1+1+$ 




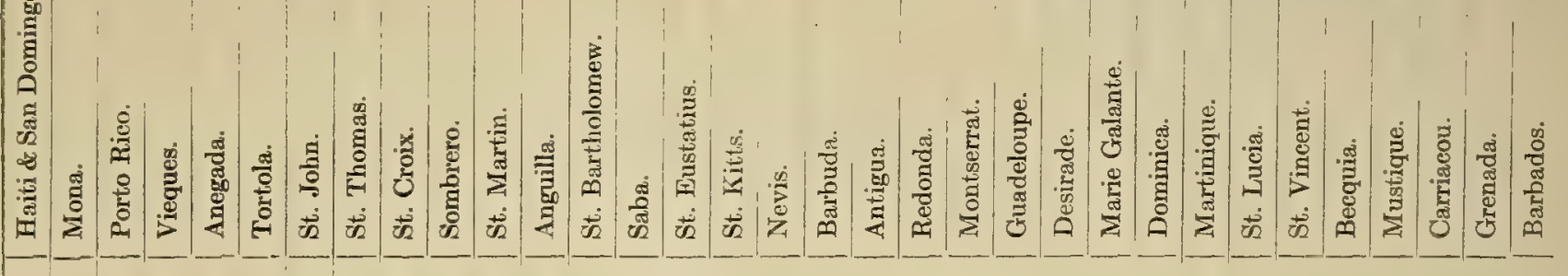



REPTUA

Arativa exol Copo

Amaiva alboguttats Boulenger

Ameiva lineolats Dumeril \&" Ribron

Ameira polops Cope

Antivs wotmorei Stejnege

Ameiva corvinn Cope

Ameiva analifera Cope

Amaiva enarmani Barthour

Aneiva erythrops Cope

Ameiva erythrocephata (Daudin)

Ameiva pleii Duméril \& Bibron

Ameiva pluvisnotata Garman

Apseiva fuscatn Garmon

Ameivn nquilinn Garno

Tisporus fuliginoous Copo

Scolecoasurus allon Barbour Scolecosaurus trinitatia Barbour

Gymnophthalmus pleii Bocourt.

Arophiebrena punctata Bell Anphishacena cubaria Pcters

Amphistbacno innoecens Woininn Amphisbuean manni Barbour

Amphisbarna caeta Cuvier

Arphish ana baleriblojege

\section{Mabuya apilonots Wiegrnann}

Mabuya aloa

Mabuya maboin Duméril \& Bibron

Mabuy laboolato Cope

Mabuya Jamcolata Cope

Mnumya domincara Garman

Mabuya Jueiac Garmo

Typlopt lumbricalis Lian

Typhlops pusill us Barbour

Typhlops tenuis Salvin

Typhlops rostcllatus Strjinerer

Typhlops platyoephalus Duméril \& Bihron

'Typhlops dominicans Btejnegar

Leptotyphlops albilrong (Wogles)

Leptotyphlops bilineata (Schlogel)

Epieratea aublavus Stojnege

Ipieratea striatus (Fischer)

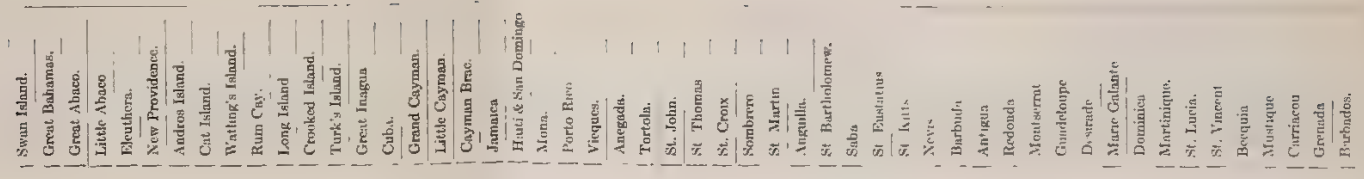

$-1+-$

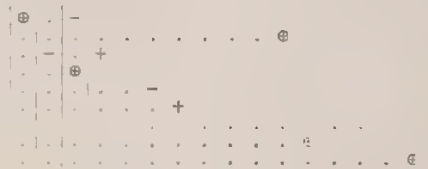

1...1.1.1.1.1.1.1.1.1.1.1.1.1.1.1.1.1.1.1.1.1...1.1.
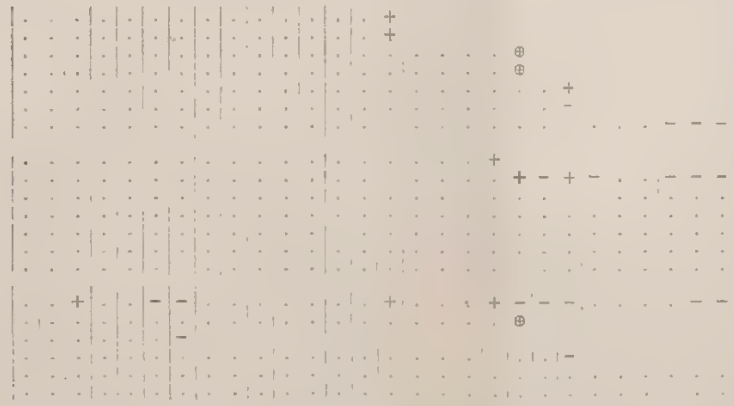



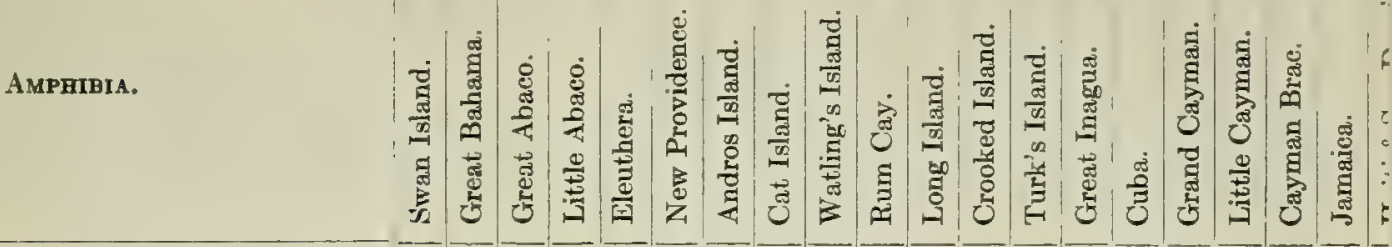

Spelerpes infuscatus Peters

Hyla septentrionalis Boulenger

Hyla vasta Cope

Hyla dominicensis (Tschudi)

Hyla brunnea Gosse

Hyla lichenata (Gosse)

Hyla pulchrilineata Cope

Bufo longinasus Stejneger

Bufo ramsdeni Barbour

Bufo peltacephalus Tschudi

Bufo gutterosus Latreille

Bufo lemur Cope

Bufo empusus (Cope)

Eleutherodactylus ricordii (Duméril \& Bibron)

Eleutherodactylus dimidiatus (Cope)

Eleutherodactylus cuneatus (Cope)

Eleutherodactylus plicatus Barbour

Eleutherodactylus varians (Gundlach \& Peters)

Eleutherodactylus luteolus (Gosse)

Eleutherodactylus jamaicensis Batbour

Eleutherodactylus weinlandi Barbour

Eleutherodactylus richmondi Stejneger

Eleutherodactylus lentus (Cope)

Eleutherodactylus unicolor Stejneger

Eleutherodactylus monensis (Meerwarth)

Eleutherodactylus auriculatus (Cope)

Eleutherodactylus antillensis (Reinhardt \& Lütken)

Eleutherodactylus martinicensis (Tschudi)

Eleutherodactylus johnstonei Barbour

Eleutherodactylus urichii (Boettger)

Leptodactylus pentadactylus (Laurenti)

Leptodactylus inoptatus Barbour

Leptodactylus validus Garman

Leptodactylus albilabris (Günther)

Phyllobates limbatus Cope

REPTILIA.

Gymnodactylus fasciatus Duméril \& Bibron

Gonatodes albogularis Duméril \& Bibron

Gonatodes notatus (Reinhardt \& Liitken)

Phyllodactylus spatulatus Cope

Thecadactylus rapicaudus (Houttuyn) 

ANPGIDYA.

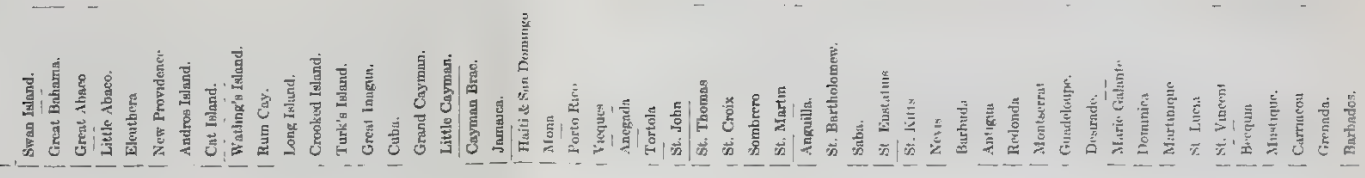

spelerpes infusentus Pcters

Hyla exptentrionadis Poulengor

Hyla vasta Cope

Hyla vasta Cope
Hyls domizicensis (Techudz)

Hyls domisiccasis (T

Hyla lichunats (Gowe)

Byle pulchrilinesta Cope

Buto longinasus 8tejneger

Bufo ramedeai Barbour

Bufo peltacephalus Tschudi

Bufo gutherosus Latreil

Bưo lemur Cope

Bufo empurus (Cope)

Eleutberodactylus ricondii (Dumínl \& Bbbron)

Elcutherodnetylus dimidistus (Cope)

Eleutherodactylus euneatus (Cape)

Gleutherodactylus plicstus Barbour

Eleutherodnctylus varians (Gundlach \& Petere)

Eleutherodactylus lutcolus (Gooso)

Elentherodactylus jarasicensis Bas bour

Dleuthorodactylus weinlandi Barbour

Eloutherodnctylus richmondi Stajneger

Eleutherodactylus lentua (Cope)

Eleutherodactylus unicolor Stejneger

Cleutherodactylus monensis (Mecrwaxth)

Eleutherodactylus auriculatus (Copc)

.

(Tachud

hii (Boettger)

Leptodactylus peaterdactylum (Lumran ti)

Leptralactylus penturdiclyling (Laurno

eptodactylus inoptatus Bartiou

Leptodactylus validus Garman

Phyllobntes limbiatus Cope

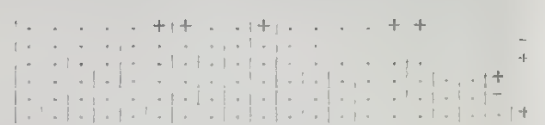

\section{RurruL}

Gymnodelylus fascistus Dumeril \& Bibron

Gonatodea albogularis Dumbril ak Bibron Gomstodes notalue (Reinhandt \& Littiken)

Phyllodeotylus apatuiatus Cope

Thecadnetylua nepiesudus (Houttuyn)
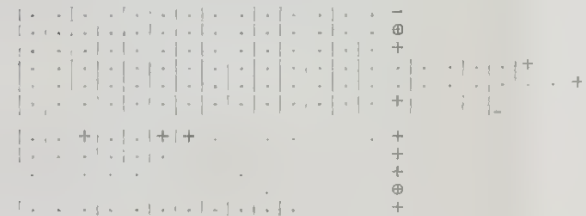


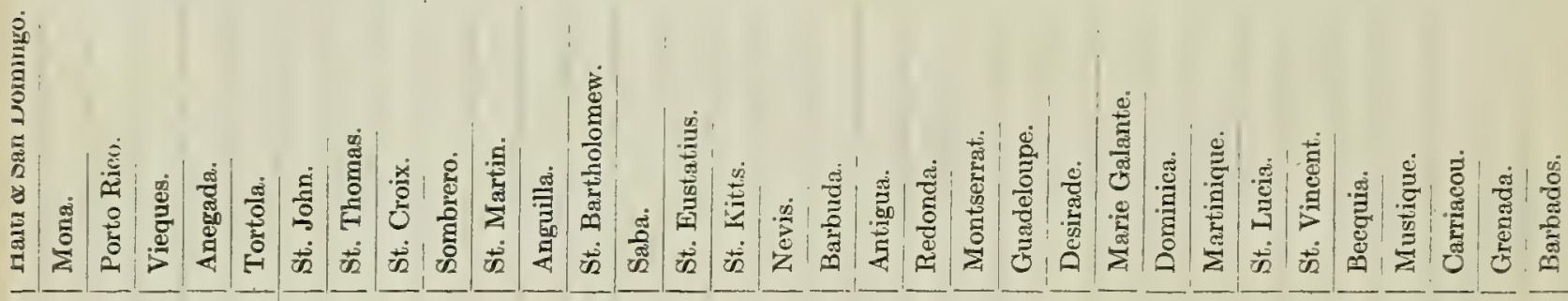

\section{t}

$\theta$

$\partial$

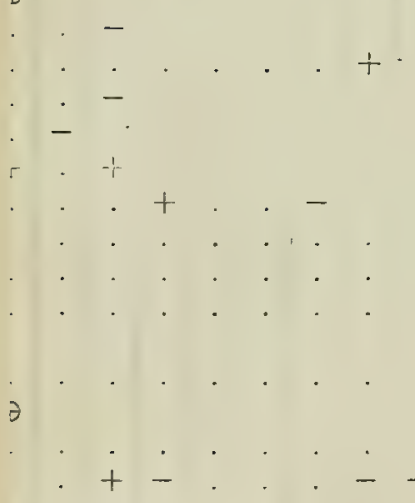

M. C. Z. 


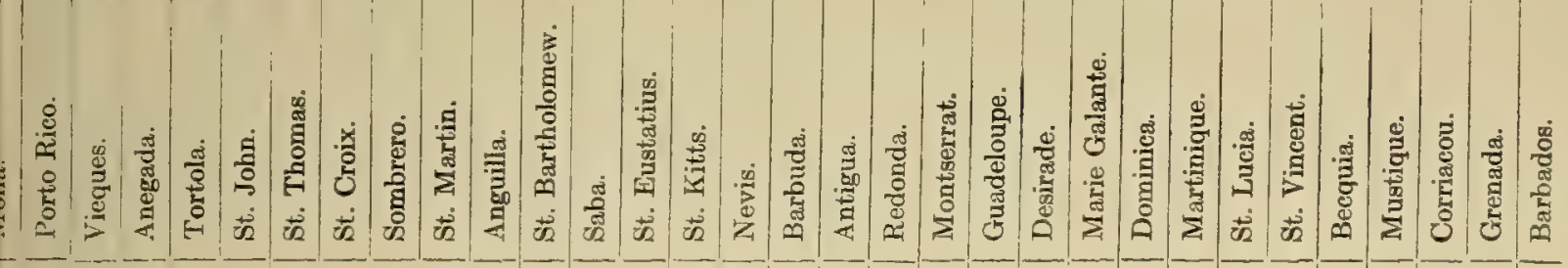

$++-c+$

$\dot{\oplus}+\dot{\oplus}+++$ 



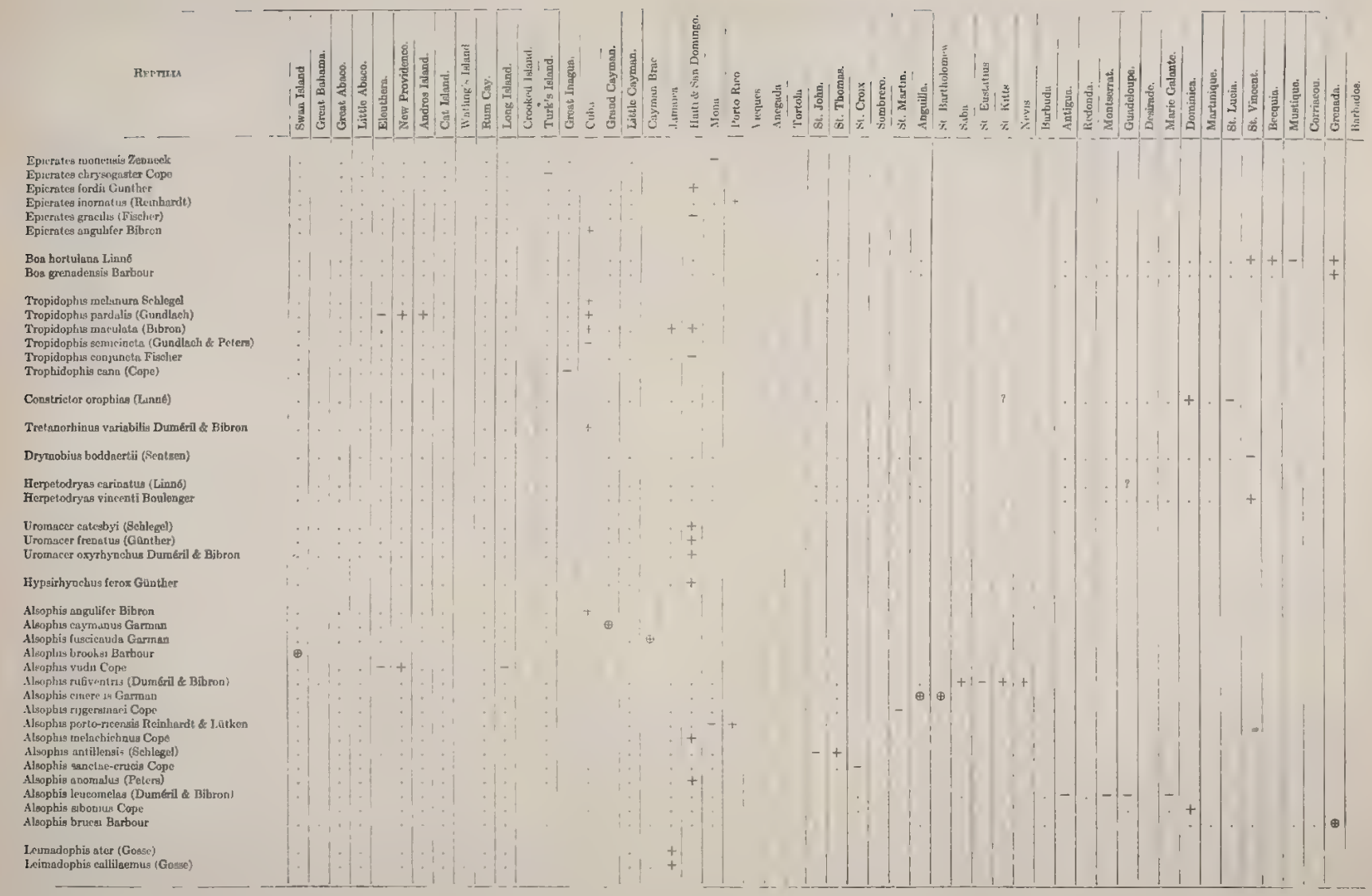


BARBOUR: ZOÖGEOGRAPHY.

Epicrates monensis Zenneck Epicrates chrysogaster Cope Epicrates fordii Günther Epicrates inornatus (Reinhardt) Epicrates gracilis (Fischer) Epicrates angulifer Bibron

Boa hortulana Linné Boa grenadensis Barbour

Tropidophis melanura Schlegel Tropidophis pardalis (Gundlach) Tropidophis maculata (Bibron) Tropidophis semicincta (Gundlach \& Peters) Tropidophis conjuncta Fischer Trophidophis cana (Cope)

Constrictor orophias (Linné)

Tretanorhinus variabilis Duméril \& Bibron

Drymobius boddaertii (Sentzen)

Herpetodryas carinatus (Linné)

Herpetodryas vincenti Boulenger

Uromacer catesbyi (Schlegel)

Uromacer frenatus (Günther)

Uromacer oxyrhynchus Duméril \& Bibron

Hypsirhynchus ferox Günther

Alsophis angulifer Bibron

Alsophis caymanus Garman Alsophis fuscicauda Garman Alsophis brooksi Barbour Alsophis vudii Cope Alsophis rufiventris (Duméril \& Bibron) Alsophis cinereus Garman Alsophis rijgersmaei Cope Alsophis porto-ricensis Reinhardt \& Lütken Alsophis melachichnus Cope

M.1 Leimadophis ater (Gosse) Leimadophis callilaemus (Gosse)
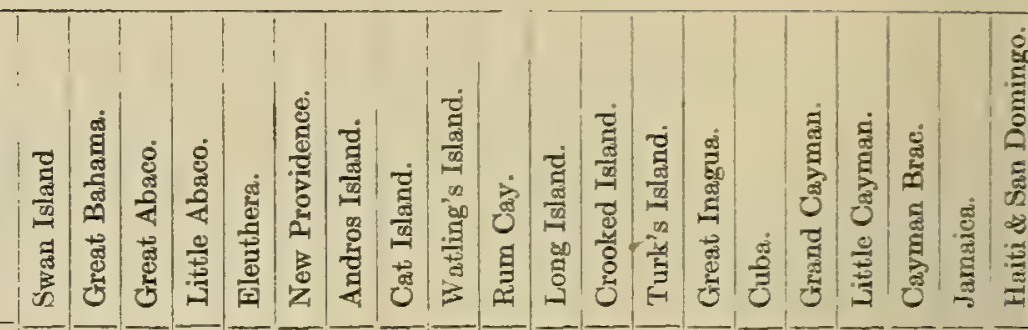
- Alsophis antillensis (Schlegel)
Alsophis antillensis (Schlegel)
Alsophis sanctae-crucis Cope Alsophis anomalus (Peters) Alsophis leucomelas (Duméril \& Bibron) Alsophis sibonius Cope Alsophis bruegi Barbour

i




年| 

Reptit/A

Leimadophis andrencac Reinhtarelt of Jatken

Lcimodophis temporalis (Cope)

Lemodophis parvitronk (Cope)

Lcirandophis cursor (Lncépede)

Lainodophis baulengeri Basboi

Lomodophis stahls Stejnegor

Leinh adiophis exiguns (Cope)

Latrnadoplis juluse (Copre)

1 inadophis mariace Barbour

1 imadophis perfuscua (Cope)

4 imodophis melnsotue (Shaw)

vothees dumerilii Bibron

Arhyton taeniatum Gonether

Crovitor vituatum (Gundlach of Peleres)

rrhyton ridimidum (Cope)

lelie cloclis (Doudin)

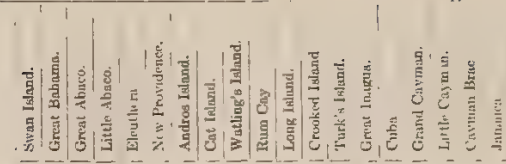

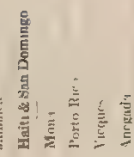

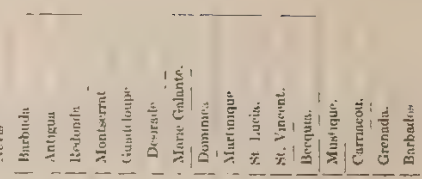

reudobon neuweidti (Duméril \& Bibran)

altria domalis Gounther

Lrcheaia lanccolntus (I acépediu)

(Thrymenyas pashatris (Gmelin)

\section{trocodilus rhombifer Cuvies} Crocodilus americanus Lausen:

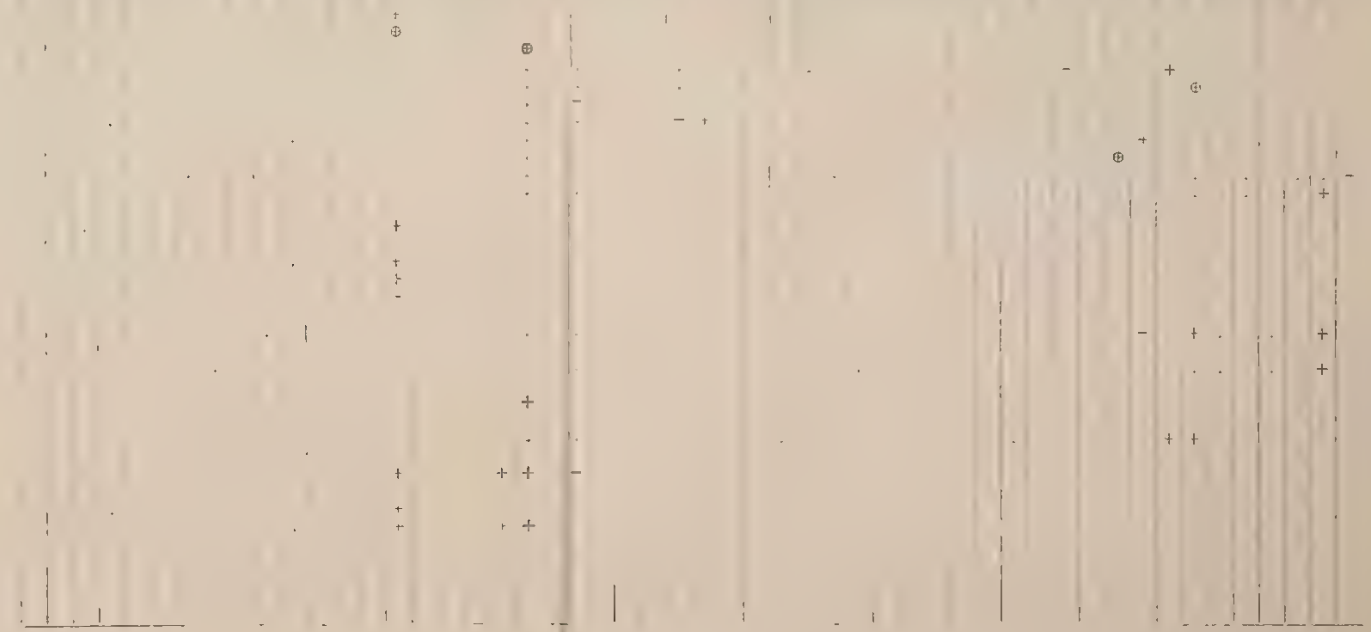



PLATE. 
PLATE.

Eleutherodactylus Johnstonei Barbour. Page 249.

Fig. 1.-Dorsal view.

Fig. 2.-Dorsal view.

Fig. 5.- Ventral view of hand.

Fig. 7.-Ventral view of foot.

Fig. 9.- Lateral view of head.

Eledtherodactrlús URICHII Boettger. Page 251.

Fig. 3.- Dorsal view.

Fig. 4.-Dorsal view.

Fig. 6.- Ventral view of hand.

Fig. 8.- Ventral view of foot.

Fig. 10.- Lateral view of head.

Scolecosaurds allent Barbour. Page 315.

Fig. 11.-Dorsal view of head.

Fig. 12.- Lateral view of head.

Fig. 13.- Ventral view of head.

Fig. 14.- Dorsal view of hand.

Fig. 15.-Dorsal view of foot. 
Herpetology of the West Indies.
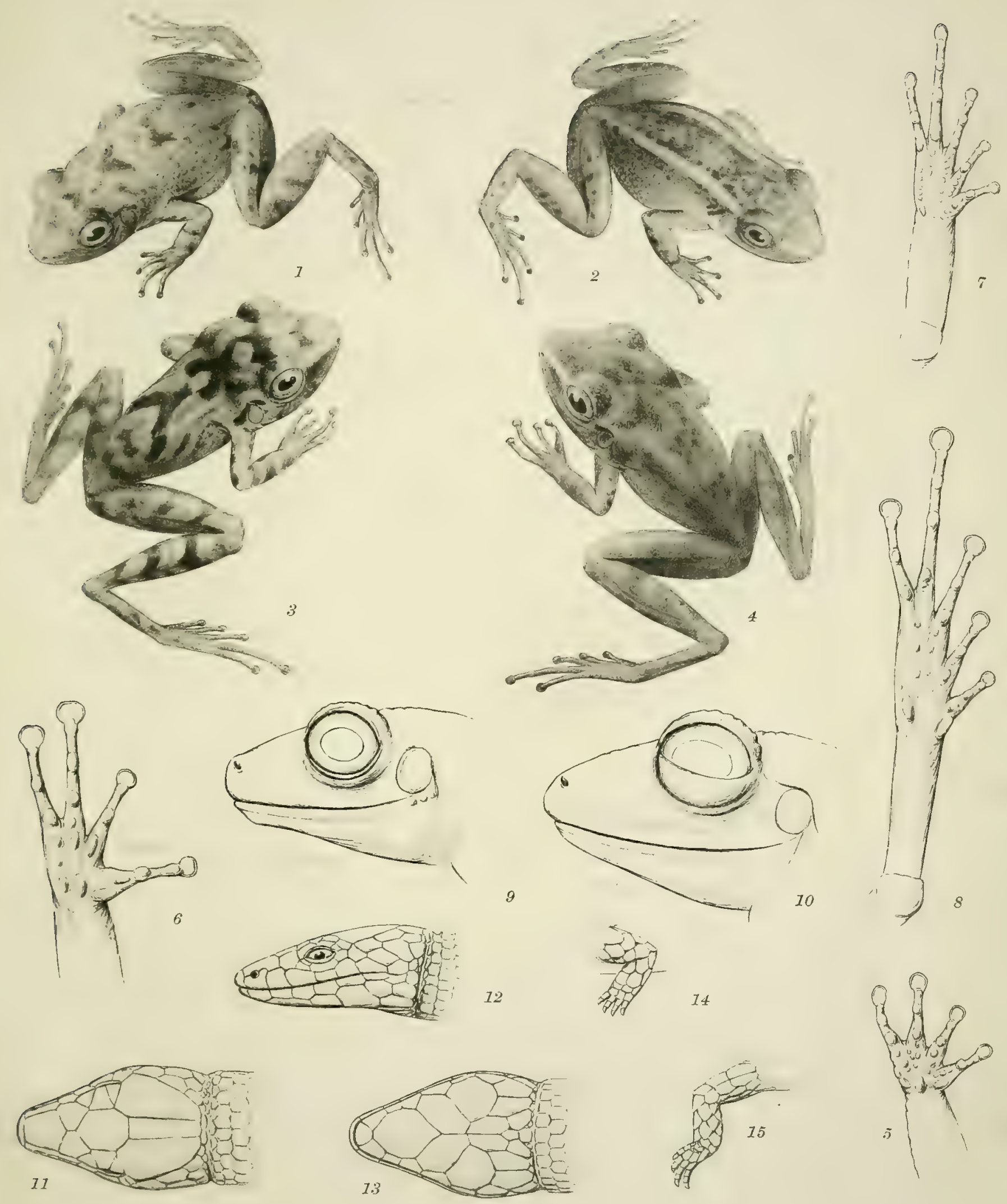




\section{PUBLICATIONS}

OF THE

\section{MUSEUM OF COMPARATIVE ZOÖLOGY AT HARVARD COLLEGE.}

There have been published of the BuLletin Vols. I. to LIV.; of the Memoirs, Vols. I. to XXIV., and also Vols. XXVI. to XXIX., XXXI. to XXXIV., XXXVI. to XXXVIII., XLI., and XLIV.

Vols. LV. to LVIII. of the BuLLETIN, and Vols. XXV., XXX., XXXV., XXXIX., XL., XLII., XLIII., XLV. to XLVIII., of the Memorrs, are now in course of publication.

A price list of the publications of the Museum will be sent on application to the Director of the Museum of Comparative Zoölogy, Cambridge, Mass. 




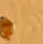

a.

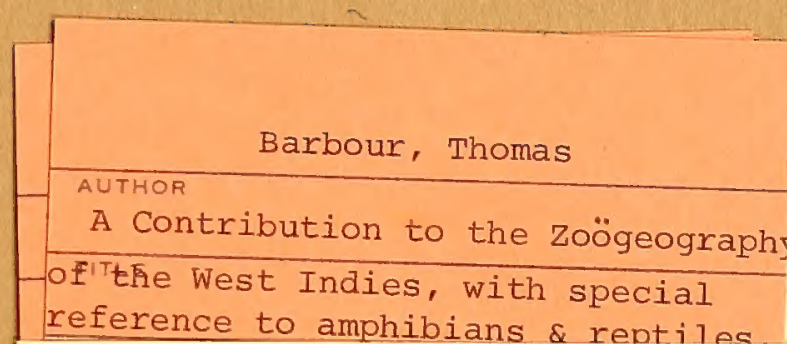


